\title{
Identification guide to the planktonic polychaete larvae around the island of Helgoland (German Bight)
}

\author{
S. Plate* \& E. Husemann** \\ Biologische Anstalt Helgoland (Meeresstation); D-27483 Helgoland, Federal Republic of \\ Germany
}

\begin{abstract}
The purpose of this work is to provide the means of identifying the planktonic larvae of the polychaete species appearing in the plankton around the island of Helgoland (North Sea). During a three-year survey in this area, the larvae of 54 species out of 24 families belonging to the orders Orbiniida, Spionida, Capitellida, Phyllodocida, Oweniida, Terebellida, Sabellida and the former Archiannelida have been recorded. Ilustrated keys to the families, genera and species are presented. To facilitate the identification, additional descriptions and information about the seasonal appearance of the species are given.
\end{abstract}

\section{INTRODUCTION}

More than 13000 species of polychaetous annelids take part in the marine benthos communities worldwide. Their distribution, species composition and population density are monitored within various benthos surveys. For the North Sea, especially the German Bight and the Wadden Sea, much information about the benthic polychaete fauna is available (Caspers, 1950; Stripp, 1969; Dörjes, 1977; Rachor \& Gerlach, 1978; Gillandt, 1979; Salzwedel et al., 1985; Rachor, 1990; Bosselmann, 1991; Kröncke, 1991). In contrast, the holoplanktonic polychaete species and the meroplanktonic polychaete larvae, which are only part of the plankton during a more or less expanded phase of their ontogenesis, have never received much attention.

Meroplanktonic polychaete larvae are seldomly recorded during studies monitoring the North Sea plankton (Smidt, 1951; Giere, 1968; Fransz, 1981; Bosselmann, 1989; Belgrano et al., 1990). Nevertheless, they occasionally play an important role in the marine zooplankton community due to their high abundance. Therefore, they may represent quite a useful source of information for ecological monitoring programmes and should be taken into account in future studies. Also, in comparative studies of marine invertebrate larvae it is often desirable to work with larvae taken directly from the plankton, since a range of stages of a number of species can be collected from plankton in far less time and with less effort than would be required to raise the same larvae in vitro. There is, however, the problem of identifying the larvae when they are collected from the plankton.

The purpose of this work is to provide the means of identifying the larvae of 54 species of polychaetous annelids from 24 families recorded during a three-year survey of the plankton around Helgoland.

- Address for correspondence: Im Ardeytal 1, D-58453 Witten, FRG

* Present address of second author: Waldstraße 62, D-32105 Bad Salzuflen, FRG 
To assist the process of identification, we prepared an illustrated key as the principle source of determination, and have provided additional descriptions of the species to ensure the accuracy of the identification. As a rule, the key and the descriptions are based on the earliest or the most typical developmental stage comprising all larval features that facilitate the identification. In early developmental stages, in which parts of the larval features are not yet differentiated, a species determination may be impossible until an appropriate stage is reached.

Although the aim of this strictly dichotomous key is to identify the larvae up to the species level, it was found that in some families it is impossible to determine the species on the basis of larval features - even at the last pelagic stage. In these cases, the key ends at the genera or family level. The family key is designed to enable a quick classification to this taxonomic level. It is followed by keys for the genera and species.

All descriptions of the morphological features were made on live material and are therefore especially suitable for the identification of living individuals. With some limitations, they will also help in identifying preserved material.

For all species, the information is given as to which season the larvae are represented in the plankton around Helgoland. This larval calendar makes the planning of seasonally restricted surveys easier, in which only special polychaete species are needed, e.g., for developmental studies.

A glossary contains most of the terms used, except those in general usage in invertebrate zoology.

\section{MATERIAL AND METHODS}

From February 1989 to December 1991 plankton samples were collected by horizontal, near-surface sampling twice a week at Helgoland Roads (Fig. 1). For the quantitative samples a net with $75 \mu \mathrm{m}$ mesh size was used. To prevent clogging of the net, especially with phytoplankton, the towing duration varied seasonally from $90-120 \mathrm{sec}$ in autumn and winter, to $60 \mathrm{sec}$ in spring and summer.

Samples were transported to the laboratory and examined as quickly as possible. For the transport, samples were transferred to a large amount of seawater $(5-8 \mathrm{l})$. At the laboratory the samples were again filtered through a net with $75 \mu \mathrm{m}$ mesh size to reduce the water volume that had to be investigated. Since the larvae are extremely mobile, it was sometimes necessary to transfer them into a small amount of water on a slide or to slightly squeeze them between slide and cover-glass for examination.

The live material was examined under a LEITZ dissecting stereomicroscope at magnifications from 10 to $40 \mathrm{x}$. Some morphological features necessary for species identification, e.g. hooded hooks, can only be detected with a light microscope using magnifications from 40 to $1000 \mathrm{x}$. These observations and most drawings were made with a LEITZ Laborlux K and an OLYMPUS IMT-2 with Nomarski differential interference contrast optics.

To investigate different developmental stages of the larvae, they were cultured under a natural temperature and light regime in the laboratory. One to 30 larvae, separated according to species, were placed in $5 \mathrm{ml}$ Boveri dishes with natural seawater and a thin layer of substrate. The seawater was changed every five days. Planktivorous larvae were fed with suspensions of the flagellate Dunaliella tertiolecta and/or the diatom Phaeodactylum tricornutum. Carnivorous larvae were nourished on Artemia sp. or small 


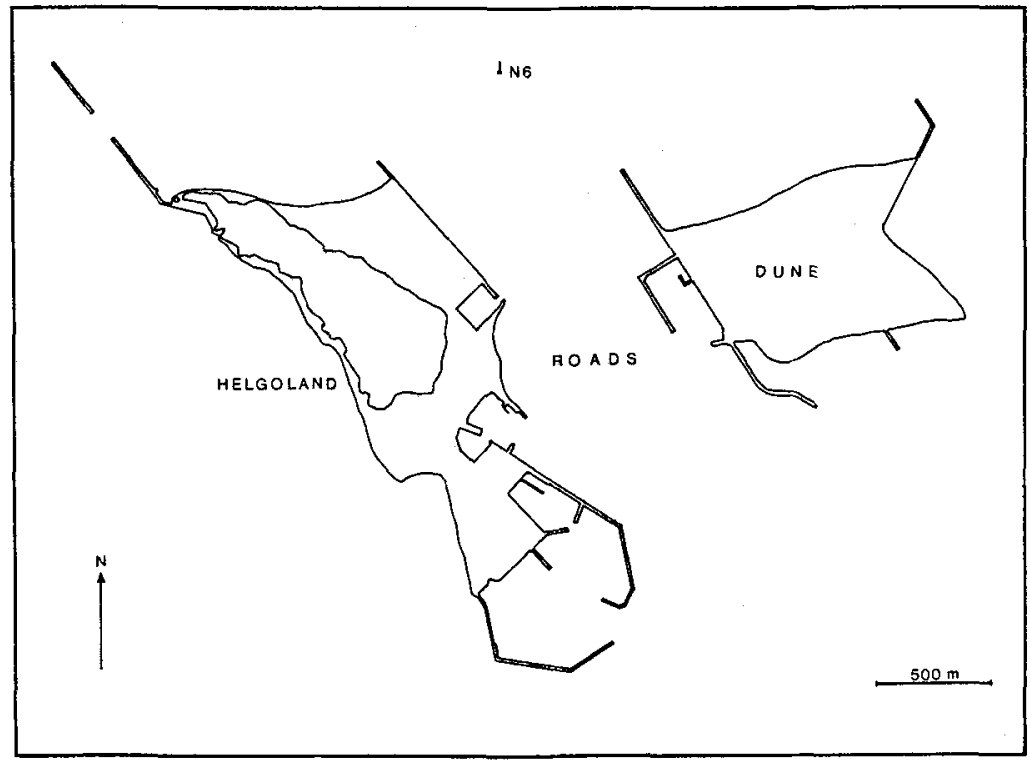

Fig. 1. Study area and location of sampling station (N6)

polychaete larvae of different species. For further details, see Husemann (1992) and Plate (1992).

\section{GLOSSARY}

acicula (pl. aciculae)

achaetous

acrotroch

antenna (pl. antennae)

anal cirrus (pl. anal cirri)

apical tuft

apical teeth (sing. apical tooth)

biramous parapodia

branchiae

capillary setae

caruncle a stout chitinous rod embedded in one or both parapodial lobes

without setae

ring of cilia in front of the prototroch

sensory appendages arising from the anterior or dorsal surface of the prostomium

elongated appendage(s) arising from the pygidium

group of cilia projecting from the anterior pole of the larvae smaller denticles or teeth situated above the main fang of the hooded hooks

two-branched; refers to the presence of setae in both rami of the parapodia; in Phyllodocidae defined as parapodia provided with aciculae in both the neuro- and notopodia gills, respiratory and highly vascularized appendages of the parapodia or the dorsal surface of the segments simple, hairlike setae; this term includes any long, slender, tapering setal type in all groups of polychaetes nuchal ridge; posterior prolongation of the prostomium as a sensory keel-shaped ridge over a variable number of segments 


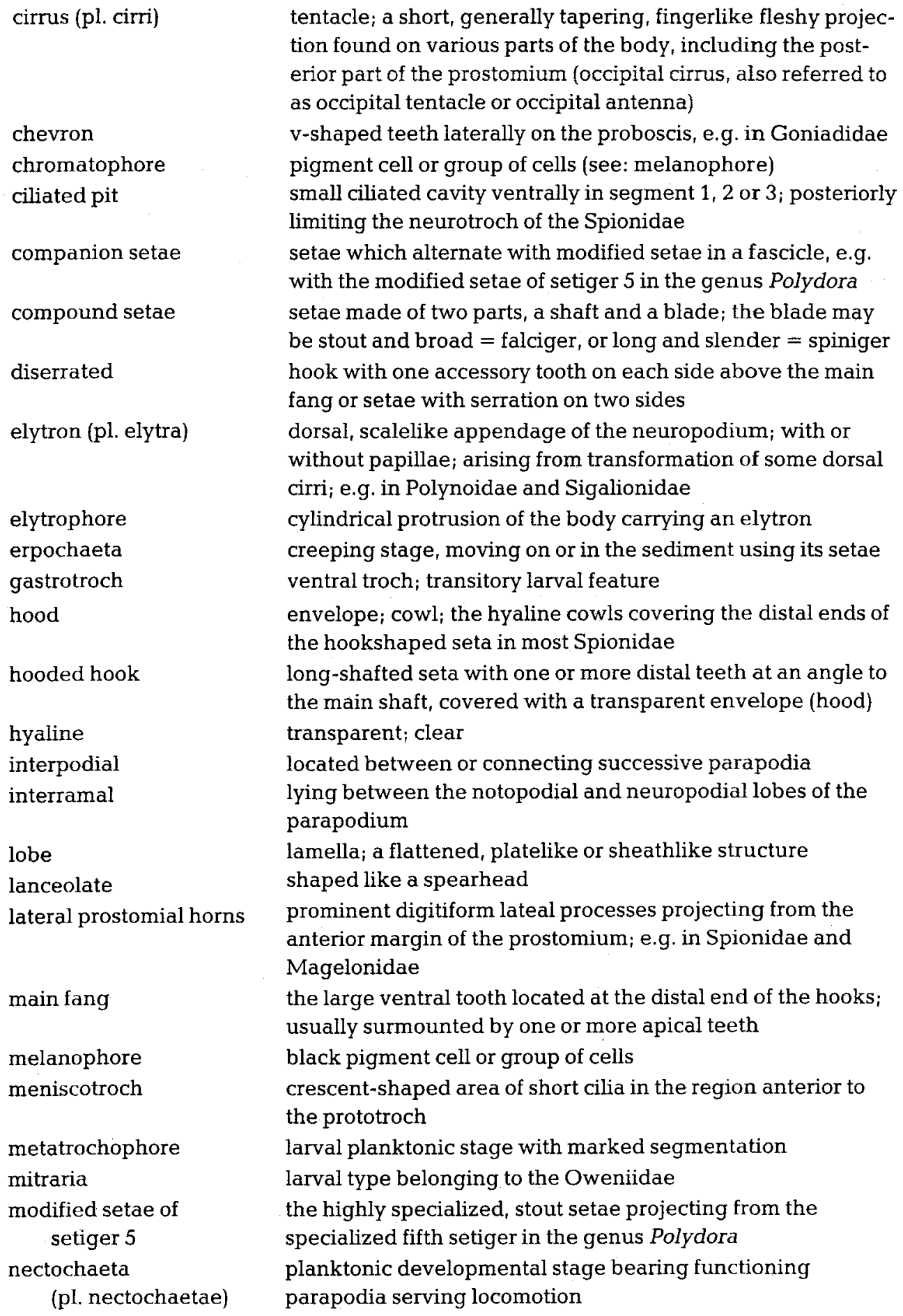

tentacle; a short, generally tapering, fingerlike fleshy projection found on various parts of the body, including the posterior part of the prostomium (occipital cirrus, also referred to as occipital tentacle or occipital antenna)

v-shaped teeth laterally on the proboscis, e.g. in Goniadidae pigment cell or group of cells (see: melanophore)

small ciliated cavity ventrally in segment 1,2 or 3 ; posteriorly limiting the neurotroch of the Spionidae

setae which alternate with modified setae in a fascicle, e.g. with the modified setae of setiger 5 in the genus Polydora setae made of two parts, a shaft and a blade; the blade may be stout and broad $=$ falciger, or long and slender $=$ spiniger hook with one accessory tooth on each side above the main fang or setae with serration on two sides dorsal, scalelike appendage of the neuropodium; with or without papillae; arising from transformation of some dorsal cirri; e.g. in Polynoidae and Sigalionidae cylindrical protrusion of the body carrying an elytron creeping stage, moving on or in the sediment using its setae ventral troch; transitory larval feature envelope cowl $_{i}$ the hyaline cowls covering the distal ends of the hookshaped seta in most Spionidae

long-shafted seta with one or more distal teeth at an angle to the main shaft, covered with a transparent envelope (hood) transparent; clear

located between or connecting successive parapodia lying between the notopodial and neuropodial lobes of the parapodium lamella; a flattened, platelike or sheathlike structure shaped like a spearhead prominent digitiform lateal processes projecting from the anterior margin of the prostomium; e.g. in Spionidae and Magelonidae the large ventral tooth located at the distal end of the hooks; usually surmounted by one or more apical teeth black pigment cell or group of cells crescent-shaped area of short cilia in the region anterior to the prototroch

larval planktonic stage with marked segmentation larval type belonging to the Oweniidae the highly specialized, stout setae projecting from the specialized fifth setiger in the genus Polydora planktonic developmental stage bearing functioning parapodia serving locomotion

\section{S. Plate \& E. Husemann}




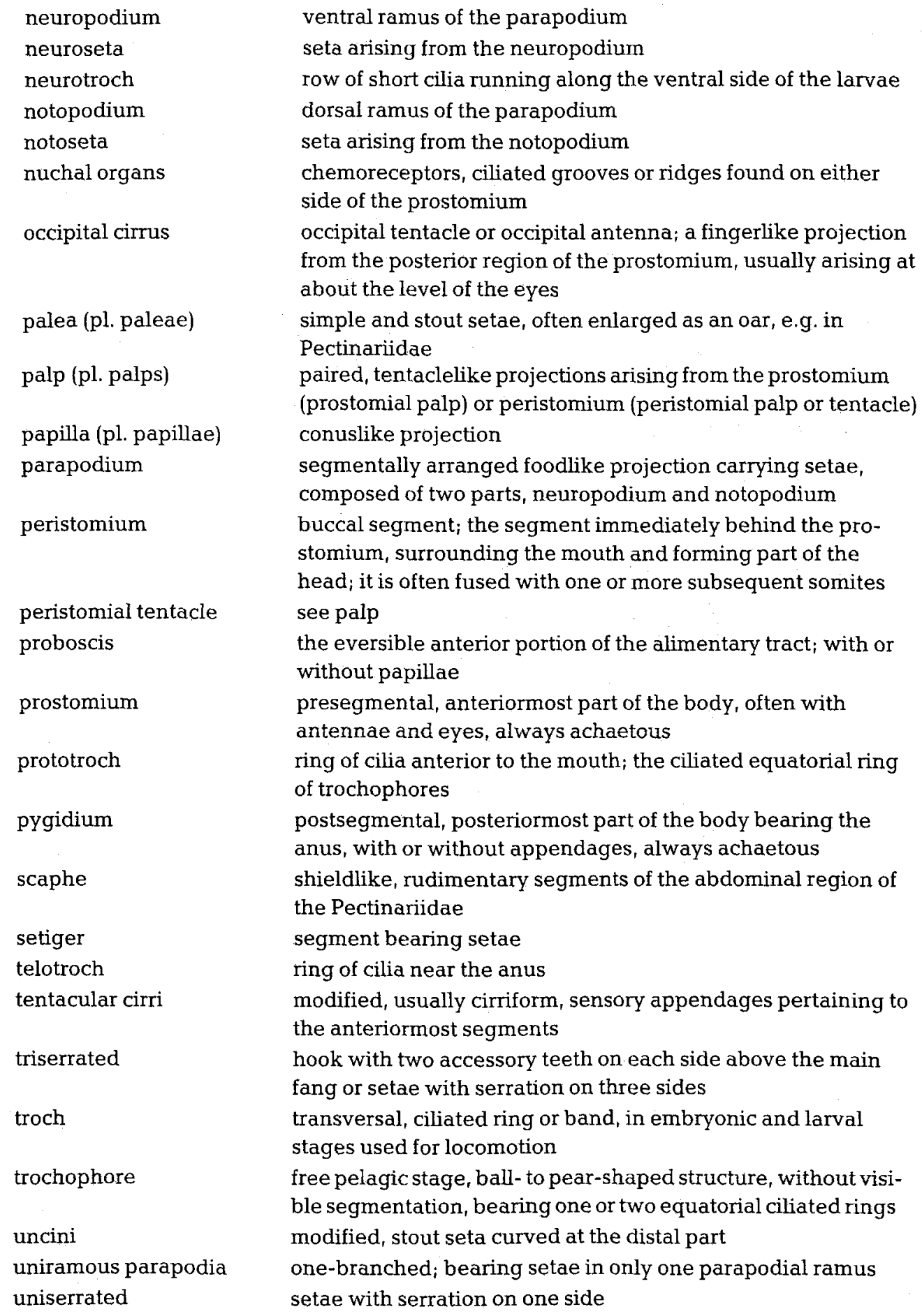




\section{KEY TO FAMILIES}

1. Parapodia totally reduced; adult setae absent; without larval setae or larval setae arranged in 2 bundles of very long setae . . . . . . . . . . . . . 2

- Parapodia \pm well developed, at least comprising of setae; larval setae arranged otherwise ........................ 4

2. Body long, slender, not surrounded by an umbrella-shaped episphere; 4 rings of cilia; 2 antennae; $2-3$ adhesive lobes at the pygidium . . . . . . Protodrilidae . . p. 8

- Body form otherwise; episphere umbrella-shaped, surrounds the following body segments; 1 ring of cilia; no antennae and anal appendages . . . . . . . . . . . 3

3. Episphere high dome-shaped, margin bended; light-yellow pigment at the prototroch; hyposphere unpigmented; long, fine, serrated larval setae, arranged in 2 bundles, iridescent . . . . . . . . . . . . . . O Oweniidae . . p. 9

- Episphere slightly dome-shaped, margin smooth; yellow pigment at the prototroch, sometimes with black chromatophores; purple pigment at the hyposphere; no larval setae . . . . . . . . . . . . . . Polygordiidae . . p. 9

4. Parapodia without setae, fins present . . . . . . . Tomopteridae . . p. 9

- Parapodia with setae, fins absent . . . . . . . . . . . . . . 5

5. Barrel-shaped larvae; with liplike pre- and postoral lobes; prototroch absent; 2 metatrochs; 1 median anal filament; larval setae absent . . . Chaetopteridae . . p. 9

- Body form otherwise; without pre- and postoral lobes; metatrochs absent or present; if with metatrochs, then always with prototroch $h_{i} 0-4$ anal appendages ${ }_{i}$ larval setae present or absent . . . . . . . . . . . . . . . . . 6

6. Dorsum covered with scalelike elytra, with or without papillae; sometimes with cylindrical elytrophores with papillae . . . . . . . . . . . . . 7

- Elytra and elytrophores absent . . . . . . . . . . . . . . . . . . 8

7. 4-5 pairs of elytra; segments without elytra carry dorsal cirri; all setae simple; 7-10 larval segments . . . . . . . . . . . . . . Polynoidae . . p. 9

- 4 pairs of elytra or elytrophores; dorsal cirri absent or small dorsal cirri only in segment 3; setae of neuropodia compound, in notopodia simple; 5-6 larval segments

Sigalionidae...p. 9

8. Larvae in hyaline, colourless tube; prostomium with an odd number of tentacles and without antennae; body in older stages separated into 2 regions; palps and tentacular cirri absent . . . . . . . . . . . . . . . Terebellidae . . p. 10

- Larvae without a tube; prostomium with or without tentacles, antennae and palps; tentacular cirri in anteriormost segments present or absent; body sometimes separated in 2 or 3 regions; if tube present, then always with 2 palps, 2 pairs of tentacular cirri and pygidium with scaphe . . . . . . . . . . . . . 9

9. A pair of extremely long, ciliated, prototrochal larval tentacles present, in older stages stronger adult tentacles originate at their base, adult tentacles with 2 longitudinal rows of papillae; prostomium flat, \pm spatulalike elongated; larval setae thin, in all segments developed, the first segment very long; body in older stages separated in 2 regions . . . . . . . . . . . . . . Magelonidae . . p. 10

- Long, prototrochal larval tentacles absent; if tentacles or palps present, they always lack longitudinal rows of papillae; prostomium otherwise; larval setae strong . . 10

10. Gastrotrochs not starting before segment 2 ; ciliated pit present or absent; larval setae 
in all segments; neuropodia with hooded hooks, not starting before segment 7; notopodia with or without hooded hooks; often with dorsal melanophores

Spionidae...p. 10

- Gastrotrochs absent, or if present, from segment 1 onwards in all following segments developed; ciliated pit absent; with or without larval setae; hooded hooks lacking, or if present, then developed in noto- and neuropodia and starting before segment 7 ; seldom with dorsal melanophores . . . . . . . . . . . . 11

11. Gastrotrochs from segment 1 onwards in all following segments; hooded hooks absent; body long and very slender, with up to 44 segments; thin larval setae in all segments . . . . . . . . . . . . . . Poecilochaetidae . . p. 13

- Gastrotrochs absent; hooded hooks present or absent; always with less than 25 segments; no larval setae, or if larval setae present, then only developed in segment

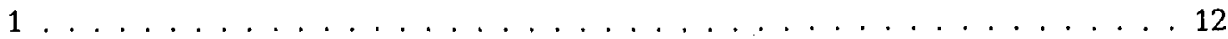

12. Long, strong, annulated larval setae in segment 1; older larval stages with serrated paleae beside the larval setae; band-shaped melanophores at the dorsum from segment 2 onwards . . . . . . . . . . . . . . . Sabellariidae . . p. 13

- Larval setae absent; without paleae, or if paleae present, then uniserrated: melanophores lacking or arranged otherwise . . . . . . . . . . . . 13

13. Prostomium with retractable prototrochal lobes; paleae uniserrated, in metatrochophore stages located in setal sacs within the body, in nectochaeta stages outside the body, surrounding the prostomium; pygidium \pm separated, with scaphe; numerous, distinct, red chromatophores; late nectochaeta in a tube

Pectinariidae... p. 40

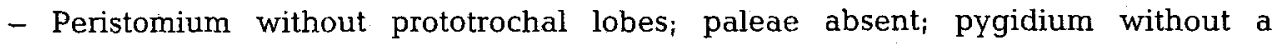
scaphe; no tube . . . . . . . . . . . . . . . . . . . . . . 14

14. Prostomium with 2-5 antennae; palps present or absent; $0-4$ pairs of tentacular cirri; compound or compound and simple setae . . . . . . . . . . . . . 15

- Antennae absent; no palps; tentacular cirri lacking; setae always simple . . . . . . 21

15. Prostomium long, conical, \pm clearly annulated; 4 antennae; tentacular cirri absent

- Prostomium otherwise 2-5 antennae 1-4 pairs of tentacular cirri

16. 0-4 eyes; parapodia of segment 1 reduced; parapodia uniramous; in erpochaeta stage proboscis with chevrons; no jaws; body opaque, brown pigmented

Goniadidae... p. 13

- Eyes absent; parapodia of segment 1 and 2 reduced, uniramous; from segment 3 onwards parapodia biramous; in erpochaeta stage proboscis with 4 jaws, no chevrons; body transparent, colourless . . . . . . . . . . . Glyceridae . . p. 13

17. Prostomium with $4-5$ antennae; $2-4$ pairs of tentacular cirri; palps absent; late nectochaeta stages with proboscis comprising papillae, jaws absent

Phyllodocidae ... p. 13

- Prostomium with 0-3 antennae; 1-4 pairs of tentacular cirri; 1 pair of palps; late nectochaeta stages with proboscis, with or without papillae; jaws present or absent

18. Antennae absent; 2 pairs of tentacular cirri in segment 1; acicula of segment 1 free, distally broad and flattened; parapodia with small spherical- to bottle-shaped dorsal and ventral cirri; compound, falciger setae, additionally 1 simple and strong capillary 
seta with stout end . . . . . . . . . . . Pisionidae . . p. 14

- 2-3 antennae; 1-4 pairs of tentacular cirri at 2-3 anterior segments; segment 1 without modified acicula; dorsal and ventral cirri otherwise; compound setae falciger or spiniger; no modified capillary setae . . . . . . . . . . . . . . . . . 19

19. 2 antennae; 1-4 pairs of tentacular cirri arise lateral to and slightly behind the prostomium; proboscis with jaws; gut with large yolk granules or oil droplets; 0-2 red pigment patches laterally on the prostomium . . . . . . . . . Nereidae . . p. 14

- 3 antennae; 2-3 pairs or tentacular cirri at 1-3 anterior segments; proboscis without jaws; gut without yolk granules or oil droplets; no red pigment patches on the prostomium . . . . . . . . . . . . . . . . . . 20

20. Antennae and prostomium with long sensory cilia; 2 pairs of red eyes; weakly developed prototroch; 2 pairs of short tentacular cirri at segment 1; compound, falciger setae . . . . . . . . . . . . . . . Syllidae...p. 14

- Antennae and prostomium without sensory cilia; 3 pairs of red eyes; prototroch well developed; 3 pairs of long tentacular cirri, located dorsally on 3 anterior segments; compound, spiniger setae . . . . . . . . . . . . . Hesionidae . . p. 14

21. Body conical, posterior tapering; telotroch weakly developed; strong capillary setae on the first 3 segments; uncini from segment 2 onwards; planktonic larvae with up to 4 segments . . . . . . . . . . . . . . . . Serpulidae . . p. 15

- Body form otherwise, posterior broad and rounded; telotroch well developed; capillary setae from segment 1 or 2 onwards; no uncini; larvae with more than 4 segments . . . . . . . . . . . . . . . . 22

22. Prostomium and pygidium broadly rounded to rectangular; prostomium, gut and pygidium blue-green pigmented, red pigmentation at the proto- and telotroch; parapodia from segment 1 onwards, parapodial lobes developed; no hooded hooks; late nectochaeta stage with a single anal cirrus . . . . . . . . . Nephtyidae . . p. 53

- Prostomium conical and tapering; pygidium broadly rounded; pigmentation otherwise; parapodia from segment 1 or 2 onwards, parapodial lobes totally reduced or not differentiated at the larval stage; hooded hooks may be present; 0 or 2 anal cirri . . 23

23. Metatrochophore stage with acro-, proto-, meta- and telotroch; additional lateral ciliary bands in all segments posterior to the metatroch-segment; nectochaeta-stage with \pm reduced trochs $s_{i}$ simple capillary setae in all segments posterior to the metatroch-segment; no hooded hooks; branchiae anlagen from segment 10 onwards; 1 pair of anal cirri . . . . . . . . . . . . . . . Orbiniidae . . p. 15

- Metatrochophore stage without acro- and metatroch; no lateral ciliary bands; apical tuft present or absent; with capillary setae and hooded hooks; no branchiae; anal cirri absent . . . . . . . . . . . . . . . Capitellidae . . p. 15

\section{KEY TO GENERA AND SPECIES}

\section{Protodrilidae}

Only one genus in the area under investigation (Fig. 2) . . Genus Protodrilus . . p. 15 


\section{Oweniidae}

Only one genus with a single species in the area under investigation

(Fig. 3) . . . . . . . . . . . . . . Owenia fusiformis . . p. 16

\section{Polygordiidae}

Only one genus with a single species in the area under investigation

(Figs 4-5) . . . . . . . . . . . . Polygordius appendiculatus ... p. 16

\section{Tomopteridae}

Only one genus with a single species in the area under investigation (Fig. 6) . . . . . . . . . . . . . . Tomopteris helgolandica . . p. 16

\section{Chaetopteridae}

Only a single genus with presumably one species in the area under investigation (Fig. 7) . . . . . . . . . . . . Chaetopterus cf. variopedatus . . p. 18

\section{Polynoidae}

1. Nectochaetae with 10 larval segments; 5 pairs of elytra; elytron surface with numerous very small papillae; 3 pairs of brown pigmented dorsal cirri (Fig. 9) . . . . . . . . . . . . . . . Harmothoe longisetis . . p. 18

- Nectochaetae with less than 10 larval segments; 4 or 5 pairs of elytra; 2-3 pairs of dorsal cirri never brown pigmented . . . . . . . . . . . . . . . . 2

2. Nectochaetae with 9 larval segments; $4-5$ pairs of elytra; elytron surface with few, small papillae; dorsal cirri in segment 3,6 and 8 developed

(Fig. 10) . . . . . . . . . . . . . . . . Harmothoe lunulata . . p. 19

- Nectochaetae with less than 9 larval segments; 3-4 pairs of elytra; at least 2 pairs of dorsal cirri . . . . . . . . . . . . . . . . . . . 3

3. Nectochaetae with 8 larval segments; elytron surface with few conical papillae; dorsal cirri at least in segment 3 and 8 developed gut brown coloured (Fig. 8) . . . . . . . . . . . . . . . . . Harmothoe cf. imbricata . . p. 18

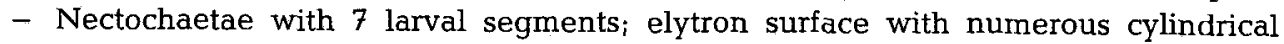
papillae; dorsal cirri only in segment 3 and 6 ; gut green-brown coloured

(Fig. 11) . . . . . . . . . . . . . . Harmothoe impar . . p. 20

\section{Sigalionidae}

1. Elytrophores with long, cylindrical papillae; setae from segment 2 onwards; small conical dorsal cirri in segment 3 in nectochaeta stage; development of elytra does not start before late nectochaeta stage (Fig. 14) . . . . . . . Pholoe cf. inornata . . p. 22

- Elytra with papillae; setae from segment 1 onwards; all segments without dorsal cirri; development of elytra starts in metatrochophore stage . . . Genus Sthenelais . . 2 
2. Elytron surface with numerous, long, cylindrical papillae (Fig. 12) . . . . . . . . . . . . . . Sthenelais boa . . p. 20

- Elytron surface smooth or only with some long, cylindrical papillae (Fig. 13) . . . . . . . . . . . . . . . Sthenelais limicola . . p. 20

\section{Terebellidae}

Only one genus with a single species in the area under investigation (Figs 15-16) . . . . . . . . . . . . . . . Lanice conchilega . . p. 22

\section{Magelonidae}

1. Body long and relatively strong; gut without yolk granules; prostomium long, flat with a broad, rectangular anterior, frontal processes absent; larval tentacles with cilia on all sides, without papillae; young larvae with up to 15 segments show a shortened left larval tentacle; papillae of adult tentacles short, beginning directly at the base of the tentacle (Figs 17, 18, 20) . . . . . . . . . . . Magelona mirabilis . . p. 24

- Body long and very slender; gut with numerous yolk granules; prostomium \pm short, rhomboid, frontal with small processes; larval tentacles without cilia, with small papillae; larval tentacles always of the same length; papillae of the adult tentacles long, not beginning directly at the base of the tentacle (Figs 19-20)

$$
\text { Magelona filiformis ... p. } 24
$$

\section{Spionidae}

1. 2 pairs of red eyes; ciliated pit present, located in segment 2 ; gastrotrochs in each segment located posterior to the ciliated pit; hooded hooks in noto- and neuropodia; dorsal melanophores absent; telotroch dorsally continuous or discontinuous . . . . 2

- 3 pairs of black eyes; ciliated pit present or absent - if ciliated pit present, then located in segment 2; gastrotrochs arranged otherwise; hooded hooks only in neuropodia; species specific arrangement of dorsal melanophores [exception: Malacoceros (Malacoceros) fuliginosus]; telotroch dorsally always discontinuous . 7

2. Prostomium trapezoid or bell-shaped; with protractile proboscis; gut with \pm prominent diverticula, light-brown or black pigmented; hooded hooks in noto- and neuropodia; telotroch dorsally continuous . . . . . . . . Genus Scolelepis . . 3

- Prostomium rounded or rectangular; protractile proboscis absent; gut without prominent diverticula, never black pigmented; hooded hooks only in neuropodia; telotroch dorsally discontinuous . . . . . . . . . . . . . . . . 5

3. Prostomium trapezoid; gut light-brown pigmented; a light-red chromatophore at the base of the parapodium at each side of the body from segment 2 onwards; beside serrated larval setae, strong, unserrated and curved capillary setae; ventrally hooded hooks from segment 17 onwards; gland cells at the prostomium absent; gastrotrochs from segment 2 onwards (Fig. 45) . . . . . Scolelepis (Scolelepis) bonnieri . . p. 34

- Prostomium bell-shaped; gut dark-brown or black pigmented; no red chromatophore at the dorsum; without strong, curved capillary setae; hooded hooks arranged otherwise; prostomium with gland cells . . . . . . . . . . . . . . . 4 
4. Prostomium orange, oesophagus and pygidium blue-green and gut dark-brown pigmented; gastrotrochs from segment 3 onwards; hooded hooks in neuropodia from segment 18 onwards, in notopodia from segment 22 onwards gland cells of the prostomium without contact with the epidermis

(Fig. 44) . . . . . . . . . . . . Scolelepis (Scolelepis) squamata . . p. 34

- Pigmentation restricted to the gut, oesophagus dark-brown, stomach black pigmented; gastrotrochs from segment 4 onwards; larvae and juveniles with up to 20 segments without hooded hooks in notopodia, hooded hooks in neuropodia from segment 18 onwards; gland cells of the prostomium with contact to the epidermis (Fig. 46) . . . . . . . . . . . . . . . . . Scolelepis sp. . . p. 36

5. Prostomium broad, rectangular, median with a slight notch; small median occipital antenna; larval setae in noto- and neuropodia well-developed; in notopodia from segment 4 onwards, beside the uniserrated setae, additional very strong, diserrated setae which are triangular in cross-section; ventral hooded hooks from segment 14 onwards (Figs 24-26) . . . . . . . . . . . . . . Laonice cf. cirrata . . p. 26

- Prostomium round to rectangular, sometimes with lateral processes occipital antenna absent; larval setae only in notopodia; no setae which are triangular in crosssection; hooded hooks arranged otherwise . . . . . . . . . . . . 6

6. Prostomium rounded, in older stages with prominent lateral processes; prostomial palps only with a longitudinal ciliated groove; gastrotrochs from segment 2 onwards; nototroch in each segment from the second onwards; a single, strong and curved capillary seta in the neuropodium of segment 1; parapodial glands from segment 5 onwards; ventral hooded hooks from segment 13 onwards; light-yellow pigment at the prostomium and pygidium; pygidium and lateral parts of the oesophagus black pigmented (Figs 42-43) . . . . . . . . . . . . Spiophanes bombyx . . p. 32

- Prostomium round to rectangular, no lateral processes; gastrotrochs from segment 4 onwards; nototrochs absent; no curved, capillary seta in segment 1 ; parapodial glands absent; peristomial palps with longitudinal ciliary groove and additional separated transverse bands of cilia; ventral hooded hooks from segment 11 onwards; yellow and black pigmentation lacking

(Figs 40-41) . . . . . . . . . . . . Prionospio (Microspio) cirrifera . . p. 32

7. Dorsal melanophores absent; larvae often with brown pigmented ventral cirrus at segment 3 ; pygidium brown, body unpigmented; ciliated pit in segment 2 ; ventral hooded hooks from segment 8 onwards; gastrotrochs in segment 3,5,7 and 9 or in each segment from setiger 3 onwards

(Figs 47-48) . . . . . . . . . . . . . . «Malacoceros fuliginosus» . . p. 36

- Dorsal melanophores present; ciliated pit present or absent; ventral hooded hooks from segment 8 onwards or starting more posteriorly; gastrotrochs from segment 3 onwards in every other segment or in fewer segments . . . . . . . . . . 8

8. Modified setae in segment 5 absent; with or without a ciliated pit; band-shaped and star-shaped melanophores never occurring in the same individual; no rosettelike melanophores; hooded hooks from segment 8 onwards or starting more posteriorly . 9

- Modified setae in segment 5 present; no ciliated pit; with band- and star-shaped or rosettelike melanophores; ventral hooded hooks from segment 7 onwards

Genus Polydora . . 11

9. Prostomium broad, with a slight median notch or rounded; dorsal melanophores 
at the base of each parapodium from segment 1 onwards and in transverse bands on the dorsum; pygidium with numerous large gland cells; ciliated pit absent; gastrotrochs in segments 5, 7 and 11; ventral hooded hooks from segment 8 onwards

(Fig. 39) . . . . . . . . . . . . . . . . Pygospio elegans... p. 32

- Prostomium rounded; dorsal melanophores not in transverse bands; pygidium without gland cells; gastrotrochs from segment 3 onwards in every other segment; ventral hooded hooks from segment 11 onwards; ciliated pit in segment 2

Genus Spio . . 10

10. 2 longitudinal rows of dorsal melanophore spots, with white centre (reflected light); dorsal dark-brown pigmented cirri; triserrated hooded hooks from segment 11 onwards, additional diserrated hooded hooks from segment 25 onwards

(Figs 22, 23A, B) . . . . . . . . . . . . . . . . Spio martinensis . . p. 26

- 2 longitudinal rows of dorsal melanophore spots, without a white centre; dorsal cirri not brown pigmented; triserrated hooded hooks from segment 11 onwards, no additional diserrated hooded hooks (Figs 21, 23B) . . . . . Spio filicornis . . p. 24

11. Body short and thick in regard to its length, \pm barrel-shaped; prostomium broadly rounded; modified setae of segment 5 arranged in a semicircle; gastrotrochs in segments 5, 7,11, 13 and 15; dorsally a single, large and star-shaped melanophores median in segment 1 and the pygidium; other segments with 4 longitudinal rows of star-shaped melanophores, often covering the whole dorsum; distinct sulphuricyellow chromatophores lateral to the prostomium and in segment 5 and 6 (Figs 36-38) . . . . . . . . . . . Polydora (Pseudopolydora) pulchra . . p. 30

- Body slender, \pm spindlelike; prostomium not broadly rounded; modified setae arranged in a straight row; arrangement of gastrotrochs and pigmentation otherwise . . . . . . . . . . . . . . . . . . . 12

12. Prostomium and pygidium slender, conically rounded; dorsal melanophores in each segment arranged in transverse bands, additional 3 median rows of rosettelike melanophores from segment 6 or 7 onwards; in all segments 1 lateral star-shaped melanophore; no star-shaped melanophores between the eyes; whole body lightgreen pigmented; modified setae with 2 lateral accessory teeth, ends with a tuft of hairs (Figs 30-32) . . . . . . . . . . . . . . Polydora (Polydora) flava . . p. 28

- Prostomium round to rectangular with a slight median notch; transverse bands of melanophores not in all segments present, no rosettelike melanophores; star-shaped melanophores between the eyes; body not green pigmented; modified setae with 1 accessory tooth, end without a tuft of hairs . . . . . . . . . . . . 13

13. Prostomium round with a slight median notch; melanophores in each segment laterally at the base of the parapodia; from segment 2 up to segment 4 melanophores arranged in transverse bands; median melanophores from segment 4 onwards in each segment 1; prostomium and pygidium light-brown pigmented

(Figs 33-35) . . . . . . . . . . . Polydora (Polydora) hermaphroditica . . p. 30

- Prostomium rectangular with \pm protruding posterior corners; melanophores in transverse bands from segment 3 to segment 6 or 7 , following segments with 2 longitudinal rows of median melanophores . . . . . . . . . . . . . . . . . . 14

14. Posterior corners of the prostornium always black pigmented; dorsal melanophores in transverse rows from segment 3 to 7,2 median rows of star-shaped melanophores from segment 8 onwards; segments ventrally without yellow chromatophores; mod- 
ified setae of segment 5 with 1 accessory tooth beneath the main fang (Figs 27-29) . . . . . . . . . . . . . . . Polydora (Polydora) ciliata . . p. 28

- Posterior corners of the prostomium seldom black pigmented; dorsal melanophores in transverse rows from segment 3 to 6 , from segment 7 onwards 2 median rows of star-shaped melanophores; middle and posterior segments ventrally with distinct yellow chromatophores; modified setae of segment 5 with 1 accessory tooth

Polydora (Polydora) ligni ... p. 28

\section{Poecilochaetidae}

Only one genus with a single species in the area under investigation

(Figs 49-50) . . . . . . . . . . . . . Poecilochaetus serpens . . p. 38

\section{Sabellariidae}

Only one genus with a single species in the area under investigation

(Fig. 51) . . . . . . . . . . . . . Sabellaria spinulosa . . p. 38

\section{Goniadidae}

1. Prostomium annulated with $7-8$ rings and $2-4$ eyes; more than 10 larval segments; interpodial ciliary bands from segment 10 onwards

(Fig. 54) . . . . . . . . . . . . . Goniadella bobretzkii . . p. 40

- Prostomium annulated with 9-10 rings; eyes absent; less than 10 larval segments; interpodial ciliary bands from segment 4 onwards

(Figs 55-56) . . . . . . . . . . . . . . . Goniada maculata . . p. 42

\section{Glyceridae}

Only one genus with a single species in the area under investigation

(Figs $57-58) \ldots \ldots$. . . . . . . . . . . . . . . . . . . . 42

\section{Phyllodocidae}

1. Prostomium with 4 antennae; 2 pairs of tentacular cirri in the anteriormost segment; dorsal cirri from segment 3 onwards . . . . . . . . . . . . . . . 2

- Prostomium with 4-5 antennae; 3-4 pairs of tentacular cirri in the anteriormost segments; dorsal cirri from seqment 4 onwards . . . . . . . . . . . . . . 3

2. Dorsal tentacular cirri longer than ventral tentacular cirri; 1 pair of eyes (Fig. 60) . . . . . . . . . . . . . . Mysta barbata . . p. 44

- Dorsal tentacular cirri as long as ventral tentacular cirri; 2 pairs of eyes (Fig. 59) . . . . . . . . . . . . . . . . E Eteone longa . . p. 42

3. Metatrochophores and nectochaetae with 4 pairs of tentacular cirri and 4 antennae . . . . . . . . . . . . . . Genus Phyllodoce . . 4

- Metatrochophores with 3 pair of tentacular cirri and 4 antennae, late nectochaetae with 3-4 pairs of tentacular cirri and 5 antennae; median antenna between the eyes 
and sometimes very small $\ldots \ldots \ldots \ldots \ldots \ldots$

4. Metatrochophores and nectochaetae with less than 15 segments; yellow pigment at the prototroch and dorsally at the anteriormost segments; proboscis with smooth papillae, extending to segment 6 (Figs 67-68) . . . . P Phyllodoce mucosa . . p. 48

- Metatrochophores and nectochaetae with more than 15 segments; red pigmented prototroch; 2 rows of red chromatophores may occur at the dorsum; proboscis with smooth and hard papillae, extending to segment 9

(Figs 65-66) . . . . . . . . . . . . . . . . Phyllodoce rosea . . p. 48

5. Segment 1 dorsally complete; all segments separated from each other; proboscis with numerous large papillae . . . . . . . . . . . . . . . . . . . 6

- Segment 1 dorsally reduced and fused with segment 2; proboscis without large

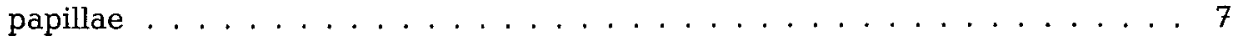

6. Metatrochophores with 3 pairs of tentacular cirri; late nectochaetae with 4 pairs of cirriform tentacular cirri; gut without yolk granules; prototroch still in nectochaetae present (Fig. 62) . . . . . . . . . . . . . . . . . . . Eulalia viridis . . p. 44

- Metatrochophores and nectochaetae with 3 pairs of tentacular cirri; ventral tentacular cirri of segment 2 flat and proximally broadened, remaining tentacular cirri cirriform; gut with yolk granules; prototroch in nectochaetae absent

(Fig. 61) . . . . . . . . . . . . . . . . Pseudomystides limbata . . p. 44

7. Yellow pigment at the prototroch; gut greenish-yellow coloured; all tentacular cirri cirriform (Fig. 63) . . . . . . . . . . . . . . Eumida sanguinea . . p. 46

- Prototroch unpigmented; gut dark brown coloured; ventral tentacular cirri of segment $2 \pm$ flat and proximally broadened, remaining tentacular cirri cirriform

(Fig. 64) . . . . . . . . . . . . . . Sige fusigera . . p. 46

\section{Pisionidae}

Only one genus with a single species in the area under investigation

(Figs 69-70) . . . . . . . . . . . . . . . . . . . Pisione remota . . p. 50

\section{Nereidae}

1. Erpochaetae with 4-9 setigers; gut with green-brown yolk granules; 2 dorsal rows of red pigment spots from segment 3 onwards

(Fig. 72) . . . . . . . . . . . . . . . . . . Neanthes succinea . . p. 50

- Erpochaetae with 4 setigers; gut with blue-green yolk granules; red pigment spots absent from the dorsum (Fig. 71) . . . . . . . . . Nereis pelagica . . p. 50

\section{Syllidae}

Only larvae of the genus Autolytus are found in the plankton

(Fig. 73) . . . . . . . . . . . . . . . . Genus Autolytus . . p. 52

\section{Hesionidae}

Only one genus with a single species in the area under investigation

(Fig. 74) . . . . . . . . . . . . . . . Ophiodromus flexuosus . . p. 52 


\section{Serpulidae}

Only one genus with a single species in the area under investigation

(Fig. 75) . . . . . . . . . . . . . Pomatoceros triqueter . . p. 53

\section{Orbiniidae}

Presumably only a single genus with one species in the area under investigation (Figs 78-80) . . . . . . . . . . . . . . . . . Scoloplos cf. armiger . . p. 53

\section{Capitellidae}

1. Larvae with up to 13 segment anlagen; segment 1 to 3 with capillary setae, from segment 4 onwards hooded hooks; apical tuft absent; gut not subdivided into several sections; body not light-green pigmented . . . . . . . . . . . Genus Capitella In the area under investigation presumably several species of the species complex "Capitella capitata» (Fig. 81). Single species cannot be determined by morphological features . . . . . . . . . . . . . . . . . . p. 54

- Larvae with up to 8 segment anlagen; segment 1 achaetous, segment 2 to 4 with capillary setae, from segment 5 onwards hooded hooks; long apical tuft present; gut subdivided into several sections; whole body light-green pigmented

In the area under investigation only one species of the genus

Genus Heteromastus

(Figs $82-83) \ldots \ldots \ldots$. . . . . . . . . . Heteromastus filiformis . . p. 54

\section{DESCRIPTION OF SPECIES}

\section{Protodrilidae}

\section{Genus Protodrilus (Fig. 2)}

6 species of the genus Protodrilus have been described for the southeastern part of the German Bight [ $P$. adhaerens Jägersten, 1952; $P$. ciliatus Jägersten, 1952; $P$. gracilis von Nordheim, 1989; $P$. helgolandicus von Nordheim, 1983; $P$. oculifer Pierantoni, 1908; $P$. purpureus Schneider, 1886] (von Nordheim, 1989). The morphological differences between the larval stages of these species are very slight and a species determination is not possible. Therefore, only a general description of the larvae is given.

The earliest pelagic larval stage is $200 \mu \mathrm{m}$ long and $50 \mu \mathrm{m}$ wide; the latest pelagic stage is $1000 \mu \mathrm{m}$ long and $80 \mu \mathrm{m}$ wide. All larval stages are worm-shaped; body long, slender with 4 cilia-rings and a ventral ciliary band; prostomium round, anterior with long cilia; 1 pair of red eyes may be developed; pygidium with 2-3 adhesive lobes; eversible fore-gut; parapodia and setae absent; gut with numerous brownish yolk granules, larval body weakly pigmented. Seasonal occurrence: IV-XII 


\section{Oweniidae}

\section{Genus Owenia}

\section{Owenia fusiformis Delle Chiaje, 1842 (Fig. 3)}

The only pelagic stage is a metatrochophore, called Mitraria, with a diameter of $400-550 \mu \mathrm{m}$ at the prototroch. The episphere is highly dome-shaped with bended margin; prototroch well developed with light yellow pigment; hyposphere flat, median with 2 bundles of long, fine, serrated larval setae, inserted in a setal sac; larval setae iridescent and 1500-1800 $\mu \mathrm{m}$ long. The Mitraria is an endolarva, meaning the worm trunk differentiates inside the epi- and hyposphere and becomes free during metamorphosis. Seasonal occurrence: V-IX

\section{Polygordiidae}

\section{Genus Polygordius}

\section{Polygordius appendiculatus Fraipont, 1887 (Figs 4-5)}

Earliest planktonic stage is a trochophore; latest stage is a metatrochophore showing the first signs of a beginning metamorphosis and has a length of $1000 \mu \mathrm{m}$. In trochophores and metatrochophores, the episphere is slightly dome-shaped with smooth margin; prototroch is well developed, yellow pigmented, sometimes with black chromatophores; 1 pair of red eyes apically located in a hemispherical protrusion; purple pigment at the hyposphere; no larval setae. The segments develop inside the epi- and hyposphere (endolarva) and are visible in metatrochophore stage. Seasonal occurrence: VII-XI

\section{Tomopteridae}

\section{Genus Tomopteris}

\section{Tomopteris helgolandica Greef, 1879 (Fig. 6)}

Earliest stages are found in plankton near the surface. These larvae have 4 segments and a length of $600 \mu \mathrm{m}$; oldest juvenile worms have 20 segments and a length of $2000 \mu \mathrm{m}$. All stages are worm-shaped; prostomium broad with a marked frontal notch; 1 pair of short antennae; 2 red eyés; all trochs reduced; long tentacular cirri in segment 1 and 2; tentacular cirri of segment 1 become reduced in juvenile worms; segment 1 in adults reduced; parapodia biramous with fins and without setae and aciculae; parapodia in older stages with yellow pigmented, rosette-formed organs from segment 3 onwards; 2 short anal cirri; larval body transparent with 1 median row of red pigment spots. Seasonal occurrence: III-XI

$T$. helgolandica is a holoplanktonic species. The early larval development is presumed to take place in near-bottom water layers (Åkesson, 1962; Husemann, 1992).

Fig. 2. Protrodilus sp.; dorsal view of a pelagic larva. Fig. 3. Owenia fusiformis; lateral view of a Mitraria larva. Figs 4-5. Polygordius appendiculatus; 4: frontal view on the episphere of a trochophore. 5: lateral view of a metatrochophore starting metamorphosis. Scale bar: 2, 3: $100 \mu \mathrm{m}$; 4, 5: $200 \mu \mathrm{m}$ 

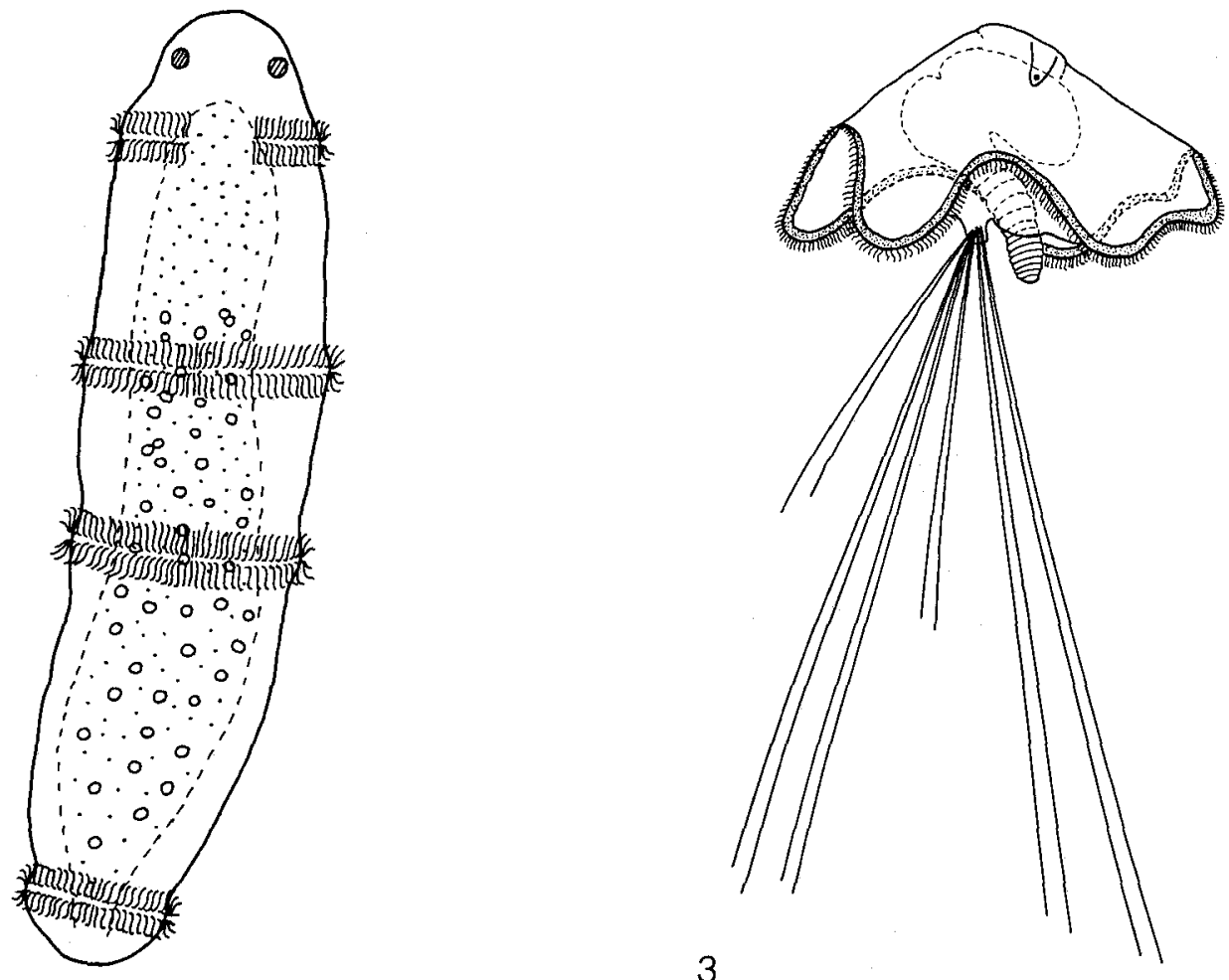

2

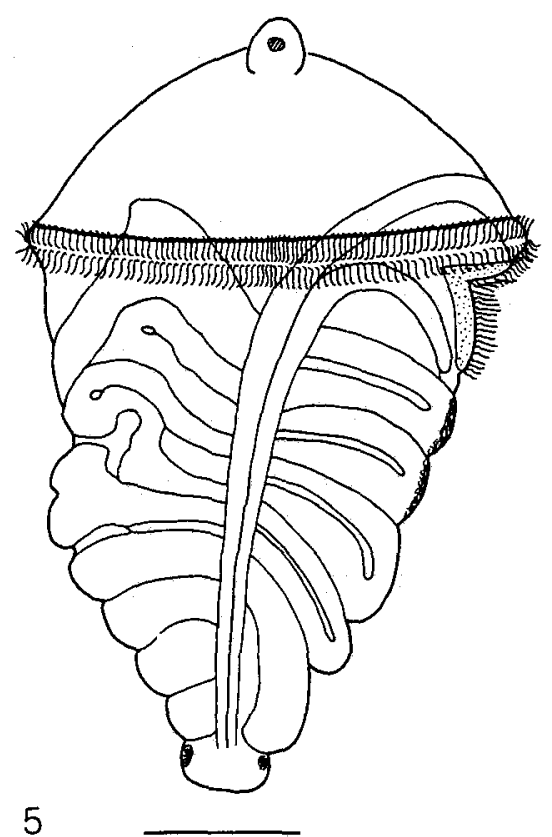

4

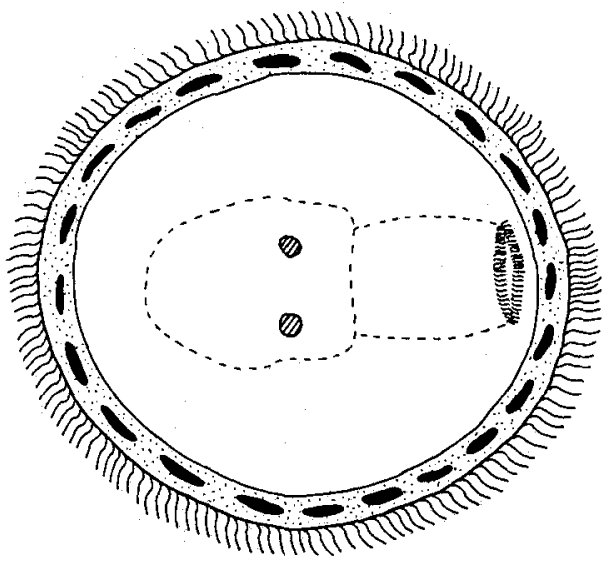

5 


\section{Chaetopteridae}

\section{Genus Chaetopterus}

\section{Chaetopterus cf. variopedatus (Renier, 1804) (Fig. 7)}

Compact, barrel-shaped larvae; all observed larvae comprised a metatrochophore stage; the body length varied from 500 to $1550 \mu \mathrm{m}$, the width from 300 to $775 \mu \mathrm{m}$. Metatrochophore with a prominent pre- and postoral lobe - the preoral lobe carries 1 pair of relatively short peristomial palps and 3 pairs of red eyes; larvae with 2 body regions; anterior region with 6 to 8 setigers and 2 well developed metatrochs; posterior region with 4 segment anlagen and a contractile median anal filament; whole body covered with short cilia; no larval setae; adult setae developed early, with enlarged modified setae in setiger 4 ; larvae totally opaque and orange-red coloured. Seasonal occurrence: V-IX

Taxonomic note: Chaetopterus variopedatus has been regarded as a single, but highly variable cosmopolitan species. There is evidence that $C$. variopedatus is a species-complex with more than 10 species in the North Atlantic and adjacent waters (Petersen, 1984). Therefore, it remains uncertain to which of these mainly undescribed species the observed larvae belong.

\section{Polynoidae}

\section{Genus Harmothoe}

Harmothoe cf. imbricata (Linné, 1767) (Fig. 8)

Earliest planktonic stage is a trochophore; latest stage is a metatrochophore with 9 segments and a length of $750 \mu \mathrm{m}$. Trochophores are oval, episphere flat with 1 pair of dark red-brown eyes; prototroch well developed. Metatrochophores are truncated triangularly, anterior flattened, with 8 segment anlagen; 3 pairs of dark red-brown eyes; 1 median antenna; acrotroch present; prototroch comprises 2 rows of cilia; stomodaeum surrounded by cilia. Nectochaetae with 8 larval segments; 2 pairs of tentacular cirri in segment 1; elytra in segment 2, 4, 5 and 7; dorsal cirri in segment 3,6 and 8 ; setae from segment 2 onwards; 1 pair of tapering anal cirri. Elytra with some conical papillae on the surface and smooth margin. The larvae are weekly bluish-green pigmented, while the gut contains dark brown coloured yolk granules. Seasonal occurrence: III-IV

Taxonomic note: The described larvae may not belong to Harmothoe imbricata s. str., because the name $H$. imbricata is used for several species which are morphologically very similar and probably stands for a species-complex (Petersen et al., 1990).

\section{Harmothoe longisetis (Grube, 1863) (Fig. 9)}

Earliest planktonic stage is a metatrochophore with a length of $500 \mu \mathrm{m}$; latest stage is a nectochaeta with 10 segments and a length of $900 \mu \mathrm{m}$. Metatrochophores are triangularly truncated, anteriorly flattened with 10 segment anlagen; 3 pairs of dark red-brown eyes; 1 median antenna; short acrotroch; prototroch comprises 2 rows of cilia; stomodaeum surrounded by cilia. Nectochaetae with 10 larval segments; 2 pairs of tentacular cirri in segment 1 ; elytra in segment $2,4,5,7$ and 9 ; dorsal cirri in segment 3,6 , 8 and 10; setae from segment 2 onwards; 1 pair of slender anal cirri. Elytra with numerous, very small papillae on the surface and smooth margin. Dorsal cirri long, 

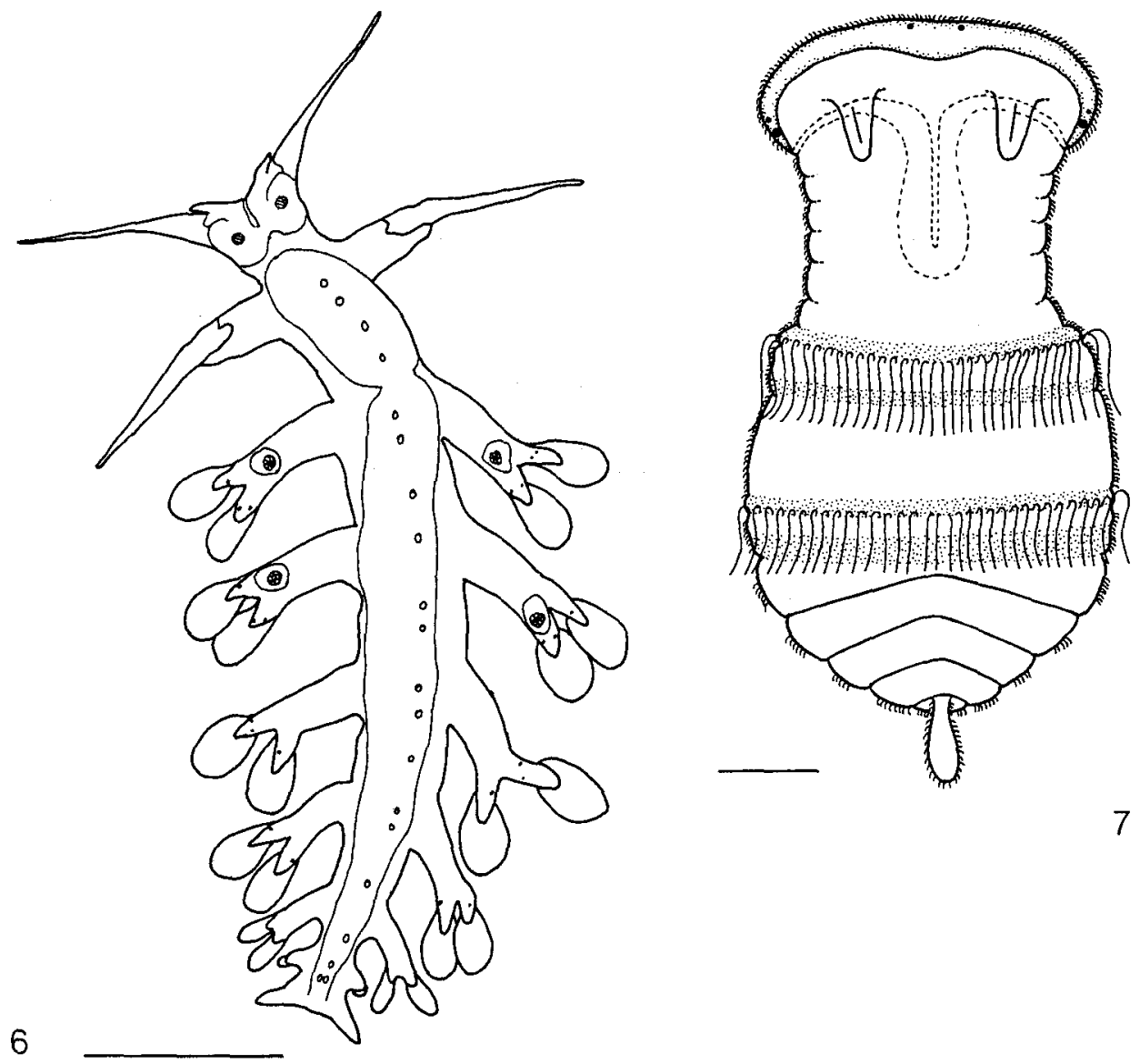

Fig. 6. Tomopteris helgolandica; dorsal view of a larva with 7 segments. Fig. 7 . Chaetopterus cf. variopedatus; dorsal view of a planktonic metatrochophore. Scale bar: 6: $500 \mu \mathrm{m}, 7: 200 \mu \mathrm{m}$

slender and intensely brown pigmented. Larvae greenish coloured, gut with yolk granules. Seasonal occurrence: VII-X

\section{Harmothoe lunulata (Delle Chiaje, 1841) (Fig. 10)}

Earliest planktonic stage is a metatrochophore; latest stage is a nectochaeta with 9 segments and a length of $780 \mu \mathrm{m}$. Metatrochophores are triangularly truncated, anteriorly flattened, with 9 segment anlagen; 3 pairs of dark red-brown eyes; 1 median antenna; short acrotroch; prototroch comprises 2 rows of cilia; stomodaeum surrounded by cilia. Nectochaetae with 9 larval segments; 2 pairs of tentacular cirri in segment 1 , elytra in segment $2,4,5,7$ and 9 ; dorsal cirri in segment 3,6 and 8 ; setae from segment 2 onwards; 1 pair of slender anal cirri. Elytra with few, small papillae on the surface and smooth margin. Dorsal cirri always unpigmented. Larvae weakly greenish-brown pigmented, gut with yolk granules. Seasonal occurrence: VII-IX 
Harmothoe impar (Johnston, 1839) (Fig. 11)

Only planktonic stage observed is a metatrochophore with 7 segments and a length of $270-450 \mu \mathrm{m}$. Metatrochophores are triangularly truncated, anteriorly flattened, with 7 segment anlagen; 3 pairs of dark red-brown eyes; 2 small, lateral antennae; short acrotroch; prototroch comprises 2 rows of cilia; stomodaeum surrounded by cilia. Nectochaetae with 7 larval segments; 1-2 pairs of tentacular cirri in segment 1, the dorsal tentacular cirri develop before the ventral tentacular cirri; elytra in segment 2, 4, 5 and 7; small dorsal cirri in segment 3 and 6; setae from segment 2 onwards; 1 pair of tapering anal cirri. Elytra with numerous cylindrical papillae on the surface and smooth margin. Larvae brownish pigmented, gut dark green coloured with yolk granules. Seasonal occurrence: VII-IX

\section{Sigalionidae}

\section{Genus Sthenelais}

Sthenelais boa (Johnston, 1839) (Fig. 12)

Earliest pelagic stage is a trochophore; latest stage is a metatrochophore with 6 segments and a length of $460 \mu \mathrm{m}$. Trochophores are oval; episphere flat with 1 pair of dark-red eyes; hyposphere posterior tapering; prototroch without pigmentation. Metatrochophores conical-shaped with dome-shaped prostomium; 3 pairs of dark-red eyes; 1 median antenna; prototroch well developed; stomodaeum surrounded by cilia; 2 pairs of tentacular cirri in segment 1 ; elytra in segment 2,4 and 5 ; setae in all segments. Elytra surface and margin with numerous long, cylindrical papillae. One pair of slender anal cirri and a median anal papilla. Larvae brownish pigmented, gut blue-green coloured with yolk granules. Seasonal occurrence: VII-VIII.

\section{Sthenelais limicola (Ehlers, 1864) (Fig. 13)}

Earliest pelagic stage is a trochophore; latest stage is a metatrochophore with 5 segments and a length of $300 \mu \mathrm{m}$. Trochophores are oval; episphere flat with 1 pair of dark-red eyes; hyposphere posterior tapering; red chromatophores at the prototroch; gut with yolk granules, posterior greenish-blue pigmented. Metatrochophores conicalshaped with dome-shaped prostomium; 3 pairs of dark-red eyes; a median antenna; prototroch well-developed; stomodaeum surrounded by cilia; 2 pairs of tentacular cirri in segment 1, elytra in segment 2, 4 and 5; setae in all segments. Elytra with smooth surface or only with some long cylindrical papillae, margin with numerous papillae comprising filamentous processes. One pair of slender anal cirri and a median pygidial papilla. Larvae brownish pigmented. Seasonal occurrence: IX-XI

Fig. 8. Harmothoe cf. imbricata; dorsal view of a nectochaeta with 8 segments. Fig. 9. Harmothoe longisetis; dorsal view of a nectochaeta with 10 segments. Fig. 10. Harmothoe lunulata; dorsal view of a nectochaeta with 9 segments. Fig. 11. Harmothoe impar; dorsal view of a nectochaeta with 7 segments. Scale bar: $100 \mu \mathrm{m}(9,10$ after Cazaux, 1968; 11 after Rasmussen, 1956) 


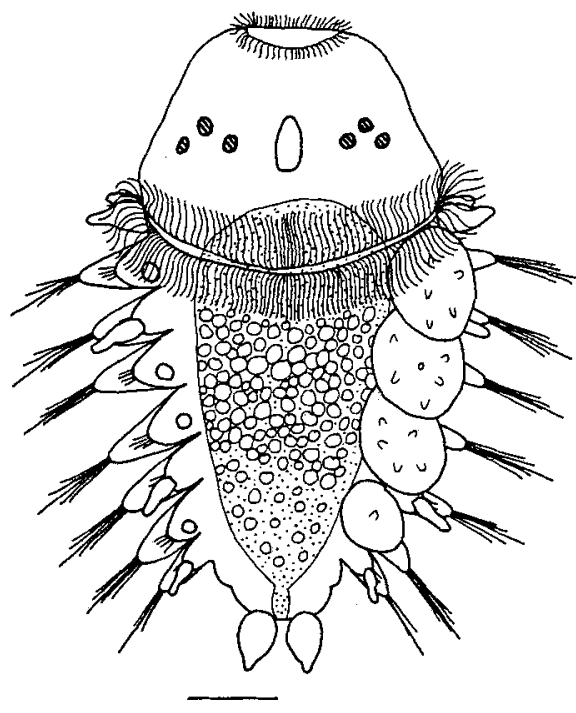

8

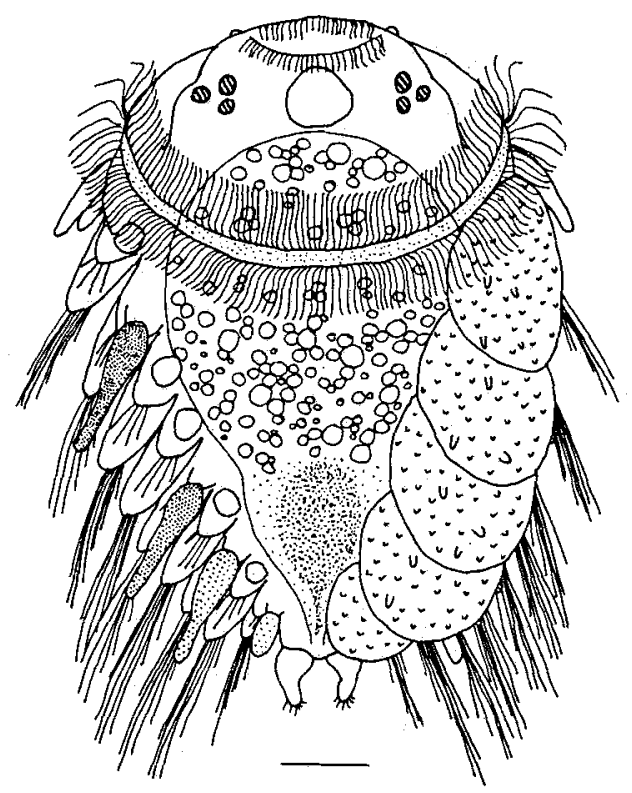

9

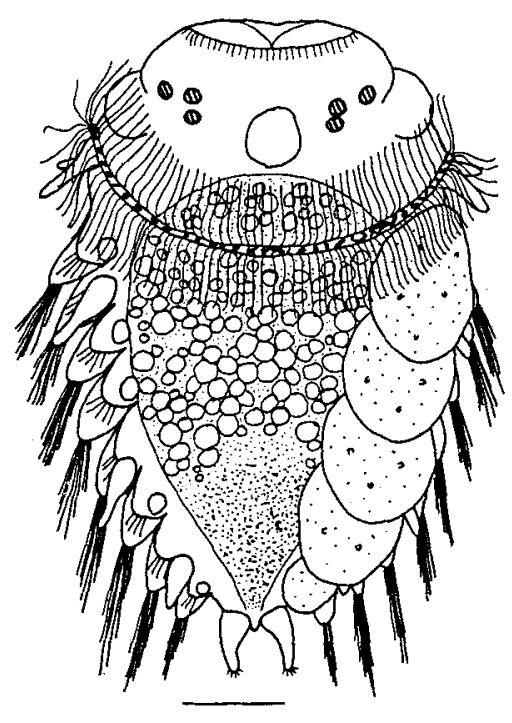

10

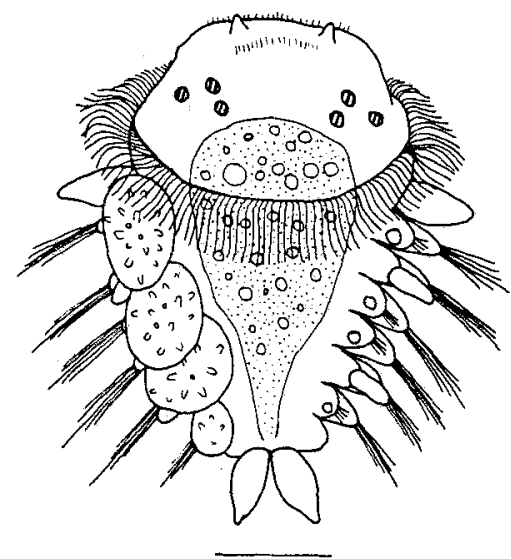

11 


\section{Genus Pholoe}

Pholoe cf. inornata Johnston, 1839 (Fig. 14)

Earliest pelagic stage is a trochophore; latest stage is a metatrochophore with 6 segments ( 5 setigers) and a length of $650 \mu \mathrm{m}$. Trochophores are spherical and darkbrown pigmented; prototroch present. Metatrochophores conical-shaped with flat, round prostomium; prostomium with 2 pairs of red eyes and without any visible appendages until a late nectochaeta stage is reached; prototroch consists of several rows of cilia; stomodaeum well developed and surrounded by cilia. Segment 1 achaetous, remaining segments with compound falciger setae in neuropodia and simple spiniger setae in notopodia; 2 pairs of tentacular cirri in segment 1; elytrophores with long, cylindrical papillae in segment 2,4 and 5; small conical dorsal cirri in segment 3; ventral cirri in all segments from segment 2 onwards. Tentacular and ventral cirri with small papillae. Pygidium with 2 conical anal cirri and a small pygidial papilla. A median ventral band of cilia extending from the stomadeum to the pygidium. The gut contains numerous yolk granules. All larval stages are dark-brown coloured. Seasonal occurrence: VII-VIII

Taxonomic note: Beside the larvae of Pholoe cf. inornata, the larvae of some more species of the genus Pholoe may occur in the German Bight (Husemann, 1992). Pholoe minuta s. str. does not occur in this area (Petersen, pers. comm.). Therefore, it must be considered that the individuals determined as Pholoe minuta in the German Bight (Gillandt, 1979; Bosselmann, 1991) belong to other species of the genus Pholoe.

\section{Terebellidae}

\section{Genus Lanice}

\section{Lanice conchilega (Pallas, 1766) (Figs 15-16)}

Earliest pelagic stage is a trochophore; oldest stage is a larva floating in a hyaline tube, called Aulophora, with 7 tentacles, more than 20 segments and a length of $3000 \mu \mathrm{m}$. Trochophores and metatrochophores are pear-shaped; episphere rounded and flat; acro-, proto- and telotroch present; 2 red eyes; gut with numerous dark-brown yolk granules; body brown pigmented. Aulophora stage in a hyaline tube, which may be lost sometimes; wormlike body, in older stages divided into 2 regions; prostomium round, distally with 0-7 tentacles; 1 pair of red eyes; mouth with broad upper and lower lip; thorax region with biramous parapodia; abdominal region in juveniles mostly without parapodia; notopodia with simple, spiniger setae; neuropodia with uncini; pygidium without appendages. Body weakly pigmented; gut greenish coloured. Seasonal occurrence: I-XI

Fig. 12. Sthenelais boa; dorsal view of a nectochaeta with 6 segments. Fig. 13. Sthenelais limicola; dorsal view of the left elytron of the 4 th segment. Fig. 14. Pholoe cf. inornata; dorsal view of a nectochaeta with 5 segments. Figs 15-16. Lanice conchilega; 15: dorsal view of a metatrochophore; 16: dorsal view of an Aulophora larva in a hyaline tube. Scale bar: 12-14: $100 \mu \mathrm{m} ; 15: 25 \mu \mathrm{m} ; 16$ : $200 \mu \mathrm{m}(12$ after Cazaux, 1968) 

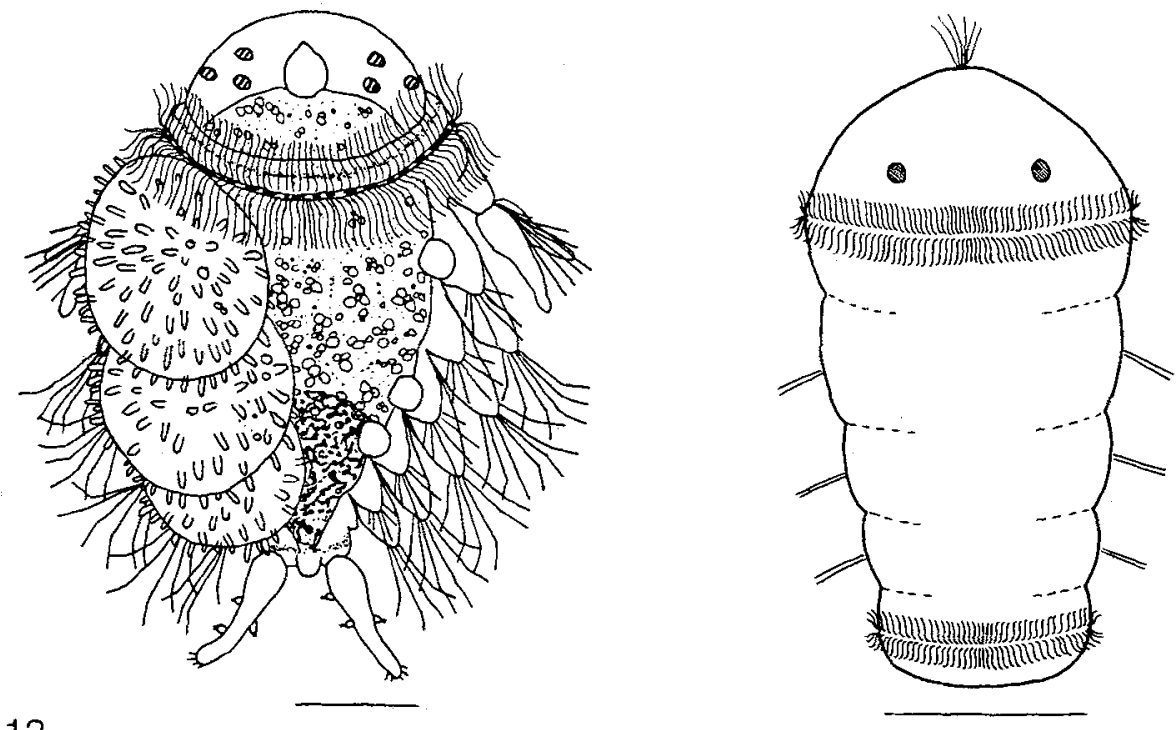

12

13
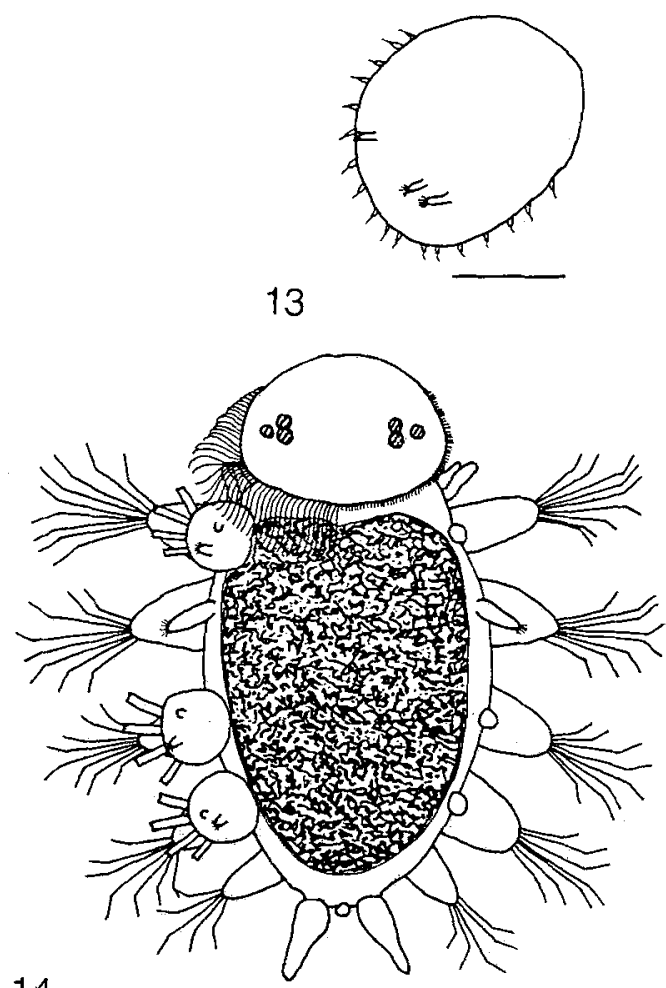

15

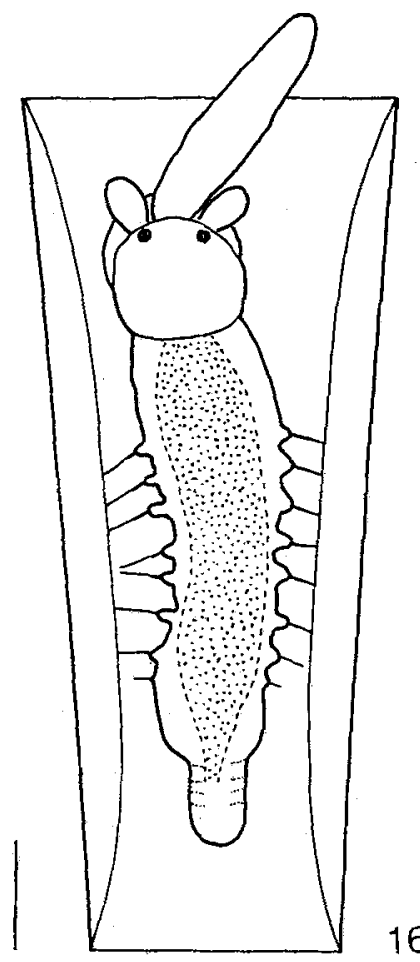




\section{Magelonidae}

\section{Genus Magelona}

Magelona mirabilis (Johnston) (Figs 17-18, 20)

Synonym: Magelona papillicornis F. Müller, 1858

Earliest planktonic stage possesses 3 setigers and a length of $150 \mu \mathrm{m}$, oldest stage with 34 setigers and a length of $\approx 3000 \mu \mathrm{m}$; the width varies from 170 to $190 \mu \mathrm{m}$ in the oldest pelagic stage. Prostomium flat, rectangular and has an elongated spatula-shape, without lateral processes; very long and ciliated prototrochal larval tentacles - the left larval tentacle is markedly shorter than the right in young larvae up to a stage with 15 setigers; from the 18-setiger stage onwards the development of the adult tentacles at the proximal part of the larval tentacles begins, adult tentacles possess 2 longitudinal rows of papillae which start directly from the base of the adult tentacle; 1 pair of brown eyes; long larval setae, especially in setiger 1; proboscis eversible; brown pigment in prostomium, tentacles, parapodia and pygidium; in parapodia additional orange chromatophores; older stages show 2 body regions: anterior part with 8 setigers, setiger 9 and 10 narrowed, forming a waist; from setiger 10 onwards diserrated hooded hooks in noto- and neuropodia; gut without yolk droplets; the small pygidium lacks appendages; telotroch absent. Seasonal occurrence: III-IX

\section{Magelona filiformis Wilson, 1959 (Figs 19-20)}

Planktonic stages observed possess 18 to 32 setigers, with a length from 1700 to $3000 \mu \mathrm{m}$ and a width from 120 to $155 \mu \mathrm{m}$. Prostomium flat, relatively short and trapezoid, anterior with lateral processes; larval tentacles at both sides of equal length, with cilia and tiny papillae; adult tentacles with 2 longitudinal rows of long and slender papillae which do not directly begin at the tentacle base but leave a gap of $\approx 50 \mu \mathrm{m}$; long and extremely fine larval setae; body very slender; gut with numerous yolk droplets; 2 body regions; from segment 10 onwards diserrated hooded hooks in noto- and neuropodia; pygidium small, without anal cirri and telotroch. Seasonal occurrence: VII-VIII

\section{Spionidae}

\section{Genus Spio}

Spio filicornis (O. F. Müller) (Figs 21, 23B)

Earliest planktonic stage has 3 segments and a body length of $280 \mu \mathrm{m}$, oldest stage has 28 segments and a length of $\approx 2100 \mu \mathrm{m}$. Larvae weakly pigmented - yellow pigment on the ventral side of the peristomium and pygidium, 2 rows of black melanophore-spots on each side of the dorsum from segment 1 onwards, dark-brown pigmented pygidium; prostomium rounded, with sensory cilia; 3 pairs of black eyes - the 2 lateral pairs

Figs 17-18. Magelona mirabilis; 17 : young pelagic stage with 10 segments, the left tentacle is shorter than the right; 18; planktonic larva with 23 segments. Fig. 19. Magelona filicornis; pelagic larva with 31 segments. Fig. 20. Diserrated hooded hook typical for both species. Scale bar: 17: $100 \mu \mathrm{m} ; 18,19$ : $200 \mu \mathrm{m} ; 20: 5 \mu \mathrm{m}$ 

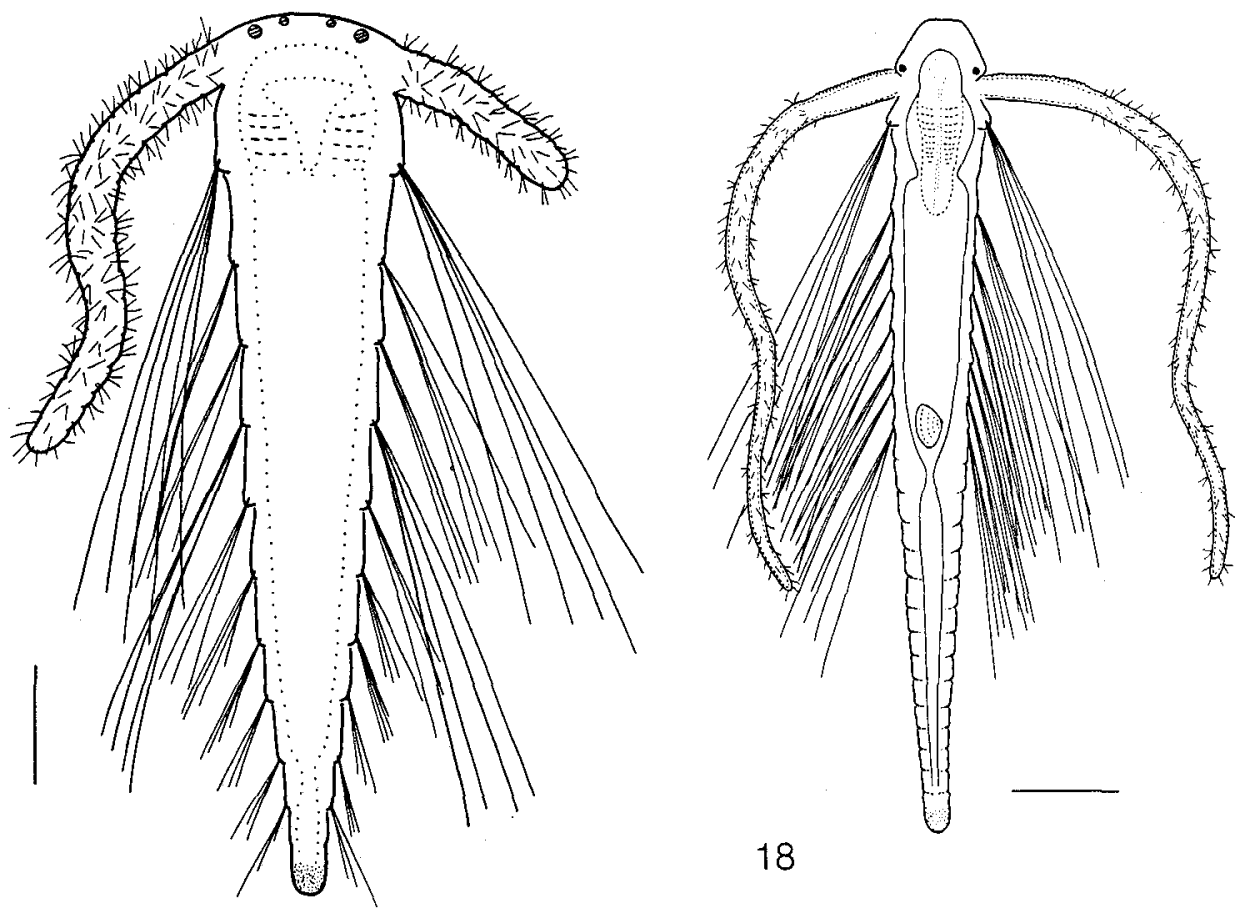

17
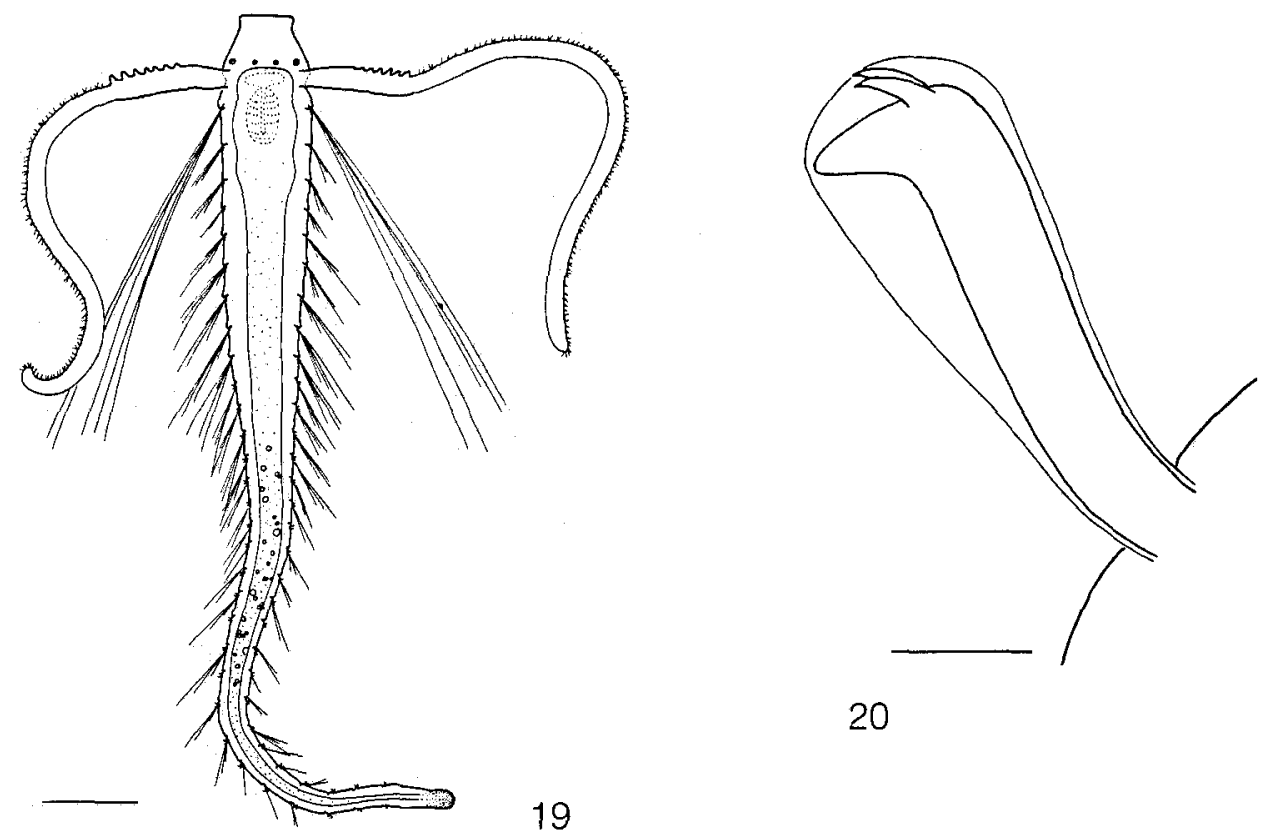
coincide; prototroch and telotroch well-developed, telotroch dorsally discontinuous; gastrotrochs in segments $3,5,7,9,11,13$ and so on; ventral ciliated pit in segment 2; caruncle small, bounded by nuchal organs; palps are short, even in older larval stages; the rounded pygidium lacks appendages; dorsal cirri without pigmentation; branchiae in older stages from segment 1 to 8 ; hooded hooks in neuropodia from segment 11 onwards, always triserrated; larval setae very long and iridescent. Seasonal occurrence: II-VI

\section{Spio martinensis Mesnil, 1896 (Figs 22, 23A-B)}

Earliest planktonic stage possesses 4 segments and a length of $\approx 280 \mu \mathrm{m}$; oldest stage has 33 segments and a length of $\approx 2800 \mu \mathrm{m}$. Larvae vividly pigmented - yellow pigment on the ventral side of the prostomium and pygidium, 2 rows of black melanophores with white centre (reflected light) on each side of the dorsum from segment 1 onwards, brown and black pigment at the pygidium; prostomium round or slightly notched at the tip; 3 pairs of black eyes, the 2 lateral pairs coincide; prototroch and telotroch well-developed, telotroch dorsally discontinuous; gastrotrochs in segments $3,5,7,9,11,13$, and so on; ciliated pit in segment 2 ; caruncle bounded by nuchal organs; palps developed early, in older stages long, reaching segment 4 ; pygidium slightly notched, in older larvae with 1 pair of anal cirri; dorsal cirri with dark brown pigment; branchiae in older stages from segment 1 to 6 or 7 ; triserrated, ventrally hooded hooks from segment 11 onwards, additional diserrated hooded hooks from segment 25 onwards; larval setae not very long but iridescent. Seasonal occurrence: V-XII

\section{Genus Laonice}

Laonice cf. cirrata (M. Sars, 1851) (Figs 24-26)

Earliest pelagic stage has 3 segments and a length of $\approx 200 \mu \mathrm{m}$; oldest pelagic stage has 19 segments and a length of $1100 \mu \mathrm{m}$. Larvae almost unpigmented; prostomium broad, rectangular and notched at the tip; palps remain relatively undeveloped and are attached on the lateral parts of the peristomium; prototroch and telotroch welldeveloped, telotroch dorsally discontinuous; 2 pairs of red eyes; little and inconspicuous occipital cirrus; no caruncle; without nuchal organs; branchiae are lacking in all pelagic stages; ciliated pit in segment 2 ; in older larvae gastrotrochs in all segments from the third onwards; larval setae in noto- and neuropodia well-developed, uniserrated setae in neuropodia, in notopodia additional strong, curved and diserrated setae which are triangular in cross-section; larvae without hooded hooks; pygidium broad with a median notch, without appendages. Seasonal occurrence: V-II

Taxonomic note: It may be possible that in the area under investigation another species, Laonice bahusiensis, is also common. The adults show only slightly morphological differences (Orrhage \&

Fig. 21. Spio filicornis; pelagic stage with 17 segments, dorsal view. Fig. 22. Spio martinensis; late planktonic larva with 21 segments, dorsal view. Fig. 23. Hooded hooks; ventral hooded hooks are developed from segment 11 onwards. In Spio filicornis only triserrated hooded hooks differentiate, in Spio martinensis the diserrated type occur from segment 25 onwards. Figs 24-26. Laonice cf. cirrata; 24: young pelagic stage with 4 segments; 25 : capillary setae of neuro- and notopodia; 26 A: strong and curved seta of the neuropodium; 26B: triangular cross-section of the former seta. Scale bar: 21 : $200 \mu \mathrm{m} ; 22: 300 \mu \mathrm{m} ; 23,26 \mathrm{~B}: 5 \mu \mathrm{m} ; 24: 50 \mu \mathrm{m} ; 25,26 \mathrm{~A}: 10 \mu \mathrm{m}$ 

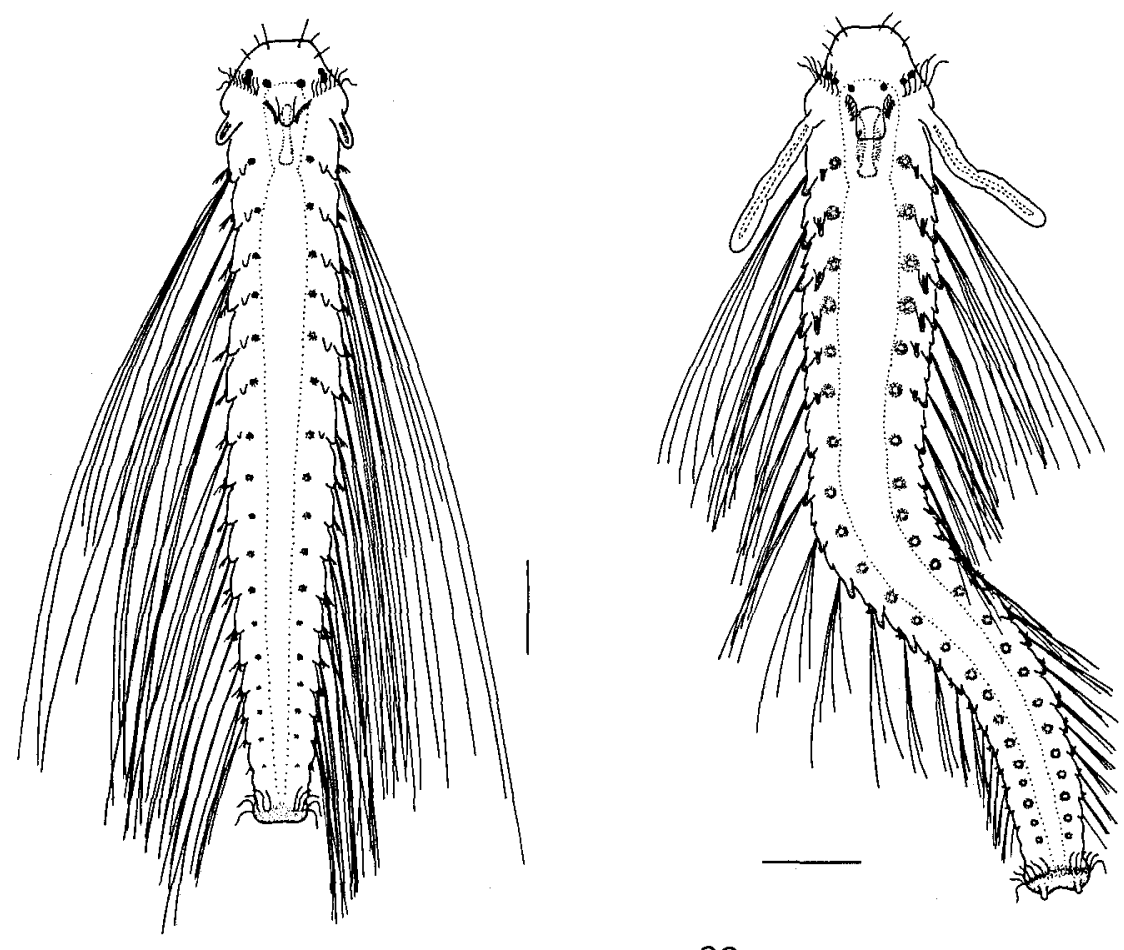

\section{2}
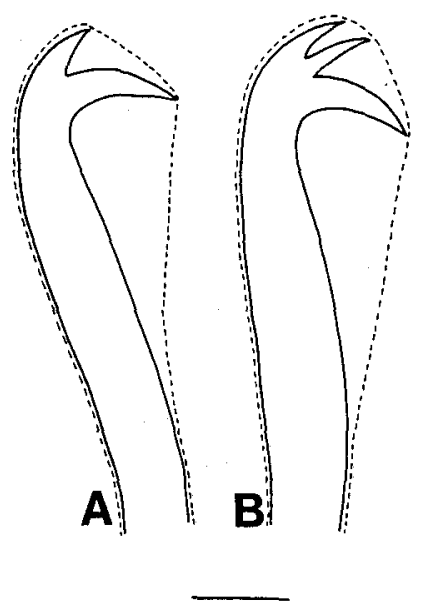

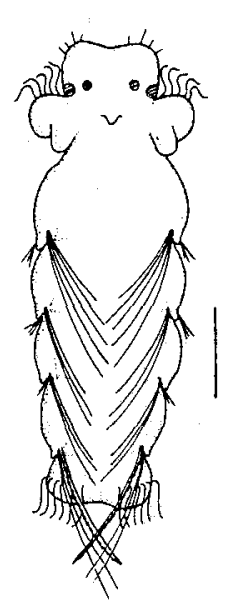

24

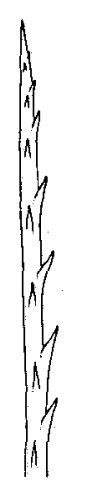

25

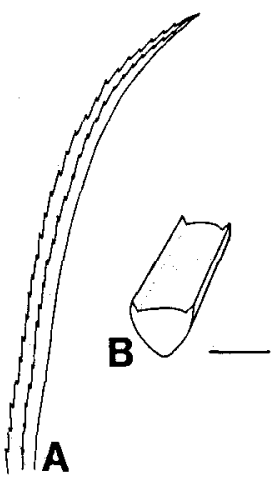

26 
Sundberg, 1990). There is no information available about morphological differences of the larvae. Therefore, it remains uncertain as to which species the observed larvae belong.

\section{Genus Polydora}

Polydora (Polydora) ciliata (Johnston, 1838) (Figs 27-29)

Earliest planktonic stage has 3 segments; oldest stage possesses 19 segments. Prostomium \pm rectangular, slightly notched, with long single cilia, and groups of short sensory cilia; 3 pairs of black eyes - a star-shaped melanophore between the first and second pair at each side; caruncle well-developed, reaching segment 2 , bounded with nuchal organs; posterior corners of the prostomium black pigmented; palps welldeveloped, reaching the fourth segment in older stages; prototroch and telotroch welldeveloped, telotroch dorsally discontinuous; body on the dorsal side with transverse bands of melanophores from segment 3 to 7,2 median rows of star-shaped melanophores from segment 8 onwards; gastrotrochs in segments $3,5,7,10,13,15,17,19$; no yellow chromatophores on the ventral side of the body; larval setae long and iridescent; diserrated hooded hooks from segment 7 onwards; modified setae in segment 5 with 1 accessory tooth beneath the main fang, modified setae arranged in a straight row, differentiated in larvae with more than 12 segments; the broad rounded pygidium lacks appendages. Seasonal occurrence: II-IX

\section{Polydora (Polydora) ligni Webster, 1879}

Early larval stages resemble Polydora (Polydora) ciliata. From the 15 segment stage onwards Polydora ( $P$.) ligni can be distinguished from Polydora ( $P$.) ciliata through their possession of following features; transverse bands of melanophores from segment 3 to 6 , 2 median rows of star-shaped melanophores from segment 7 onwards; middle and posterior body segments at the ventral side with distinct yellow chromatophores which are arranged in transverse bands; often without black pigment at the posterior corners of the prostomium. Seasonal occurrence: IV-IX, always occurring in smaller abundance than $P$. ciliata.

\section{Polydora (Polydora) flava Claparède, 1870 (Figs 30-32)}

Earliest planktonic stage with 6 segments and a length of $\approx 370 \mu \mathrm{m}_{\text {; }}$ oldest stage with 21 segments and a length of $\approx 2000 \mu \mathrm{m}$. Larvae spindle-shaped; prostomium and pygidium rounded but relatively slender, both light-green pigmented; prostomium without sensory cilia; pygidium without anal cirri; 3 pairs of black eyes; caruncle broad, flat and short (reaching segment 1), bounded by nuchal organs; palps remain short and relatively undeveloped, reaching segment 2 in late planktonic stages; proto- and telotroch weak, only with short cilia, telotroch dorsally discontinuous; dorsal pigmentation in 3 systems: in all segments transverse bands of black melanophores, 1 star-shaped melanophore on the lateral side, from segment 6 or 7 onwards additional 3 median rows

Figs 27-29. Polydora (Polydora) ciliata; 27: planktonic stage with 15 segments, dorsal view; 28: diserrated hooded hooks; 29: modified setae of segment 5 with capillary companion setae. Fig. 30. Polydora (Polydora) flava; planktonic larva with 19 segments, dorsal view. Scale bar: $27,30: 200 \mu \mathrm{m}$; 28: $10 \mu \mathrm{m} ; 29: 50 \mu \mathrm{m}$ 

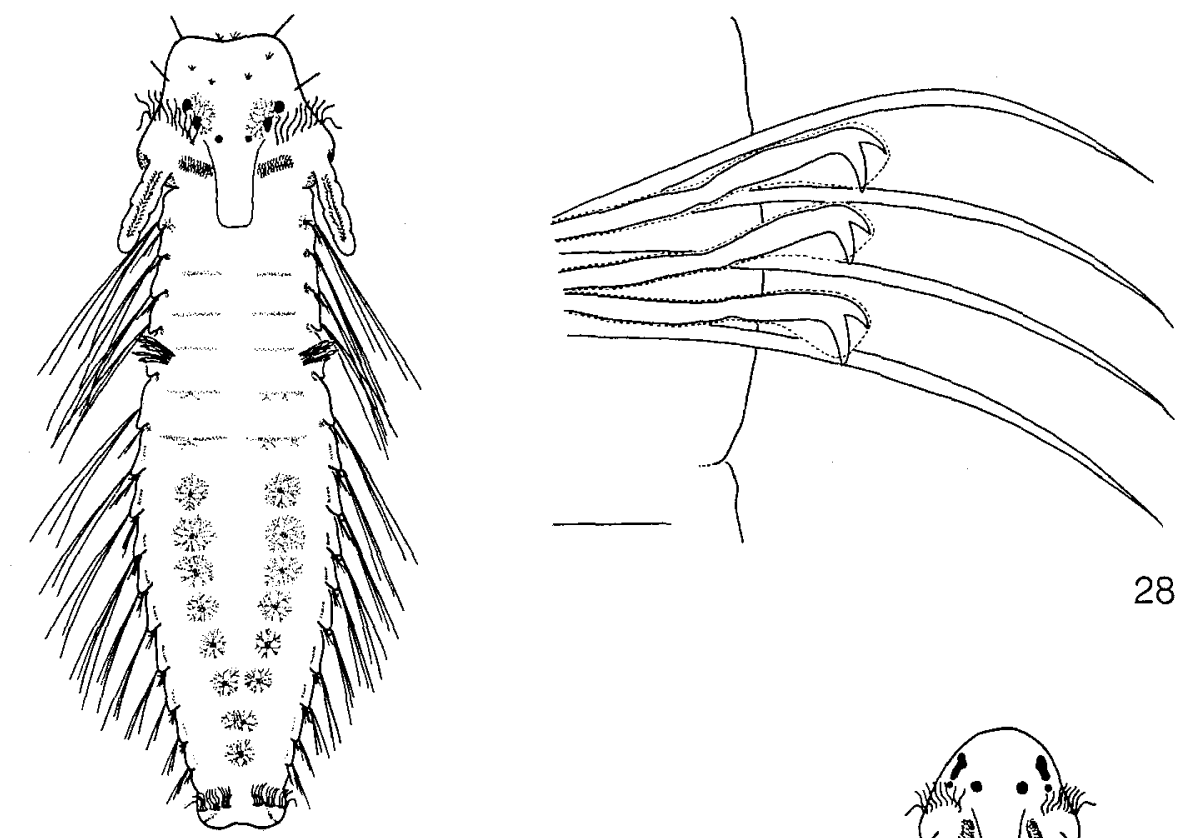

27
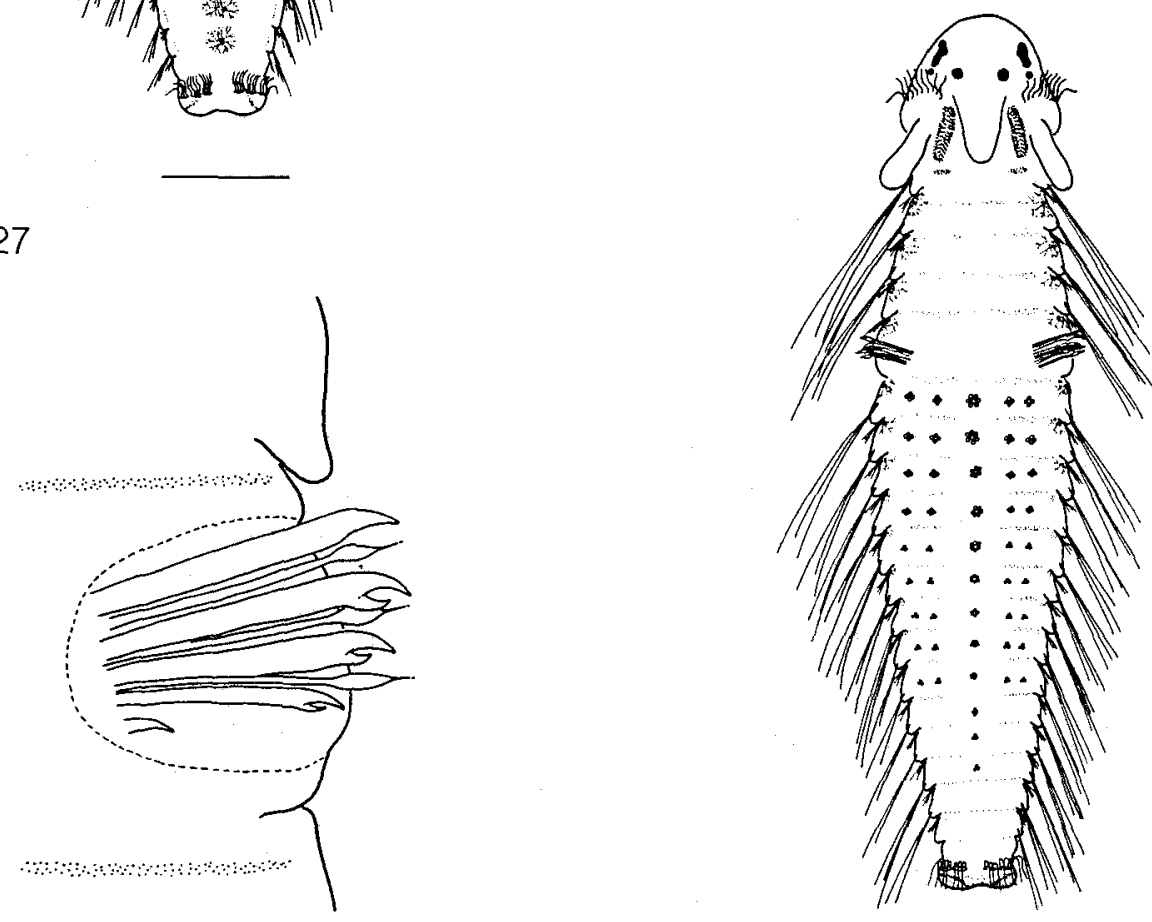
of rosettelike melanophores; larval setae short, may be lacking in the neuropodia of older stages; from segment 7 onwards diserrated hooded hooks in the neuropodia; modified setae in segment 5 with some tiny denticles beside the main fang, they are first differentiated at the 16-setiger stage; parapodial lobes weakly developed; modified setae of segment 5 arranged in a straight row; gastrotrochs in segments $3,5,7,10,13,15,17$ and 19; nototrochs from segment 2 onwards; gut with numerous yolk droplets. Seasonal occurrence: VIII-IX

\section{Polydora (Polydora) hermaphroditica Hannerz, 1956 (Figs 33-35)}

Earliest planktonic stage is comprised of 8 segments and has a body length of $\approx 400 \mu \mathrm{m}$; oldest pelagic stage has 24 segments and a length of $\approx 2000 \mu \mathrm{m}$. Slender larvae; prostomium and pygidium small, prostomium rounded, often with a slide notch, with short sensory cilia; 3 pairs of black eyes, the first often irregularly oval-shaped, a star-shaped melanophore between the first and second pair, light-brown pigment on the lateral sides of the "head"; prototroch and telotroch well-developed; telotroch dorsally discontinuous; pygidium light-brown pigmented, without appendages; caruncle in older stages broad, reaching the middle of segment 2, bounded by nuchal organs; palps relatively short, developed, reaching segment 3 late in the last pelagic stage; larval setae short; dorsal pigmentation in 3 systems: a small melanophore lateral in each segment, transverse bands of melanophores from segment 2 to 5 , a median row of ramified, starshaped melanophores from segment 6 onwards - these melanophores occur in young larval stages from segment 4 onwards, but the first 2 vanish later; diserrated hooded hooks from the seventh segment onwards; young larval stages with numerous yolk droplets in the gut; modified setae of segment 5 arranged in a straight row; gastrotrochs in segments $3,5,7,10,13,15,17,18,19$, etc. Seasonal occurrence: VI-XII

\section{Polydora (Pseudopolydora) pulchra Carazzi, 1895 (Figs 36-38)}

Earliest pelagic stage possesses 3 segments and a length of $\approx 300 \mu \mathrm{m}_{\mathrm{i}}$ oldest stage has 21 segments and a length of $\approx 1900 \mu \mathrm{m}$. Barrel-shaped larvae with vivid pigmentation: characteristic dorsal pigmentation comprising a big star-shaped melanophore median in segment 1 and the pygidium, other segments only with tiny median melanophores but with 4 rows of ramified melanophores which may cover the whole dorsum, distinct sulphuric-yellow chromatophores lateral in the peristomium and in segments 5 and 6; prostomium broad, rounded, sometimes with a slide notch, with sensory cilia; 3 pairs of black eyes, between the first and second pair at each side a big ramified star-shaped melanophore; broad caruncle which is bounded by small nuchal organs; prototroch and telotroch well-developed; telotroch dorsally discontinuous; pygidium broad with a slight notch, anal cirri absent; modified setae of segment 5 in a horseshoelike arrangement, differentiate late; diserrated hooded hooks in neuropodia from segment 8 onwards (not easily seen in pelagic stages); gastrotrochs in segments 5,7 , 11,13 and 15 ; palps reaching segment 3 . Seasonal occurrence: VI-XII

Figs 31-32. Polydora (Polydora) flava; 31: body segment; 32: modified setae of segment 5. Figs 33-35. Polydora (Polydora) hermaphroditica; 33: young pelagic stage with 7 segments; 34 : larva ready to metamorphose; 35 : modified setae of segment 5 comprising one long tooth plus slender accessory teeth at each side. Scale bar: $31: 20 \mu \mathrm{m}_{i} 32,35: 10 \mu \mathrm{m} ; 33,34: 100 \mu \mathrm{m}$ 

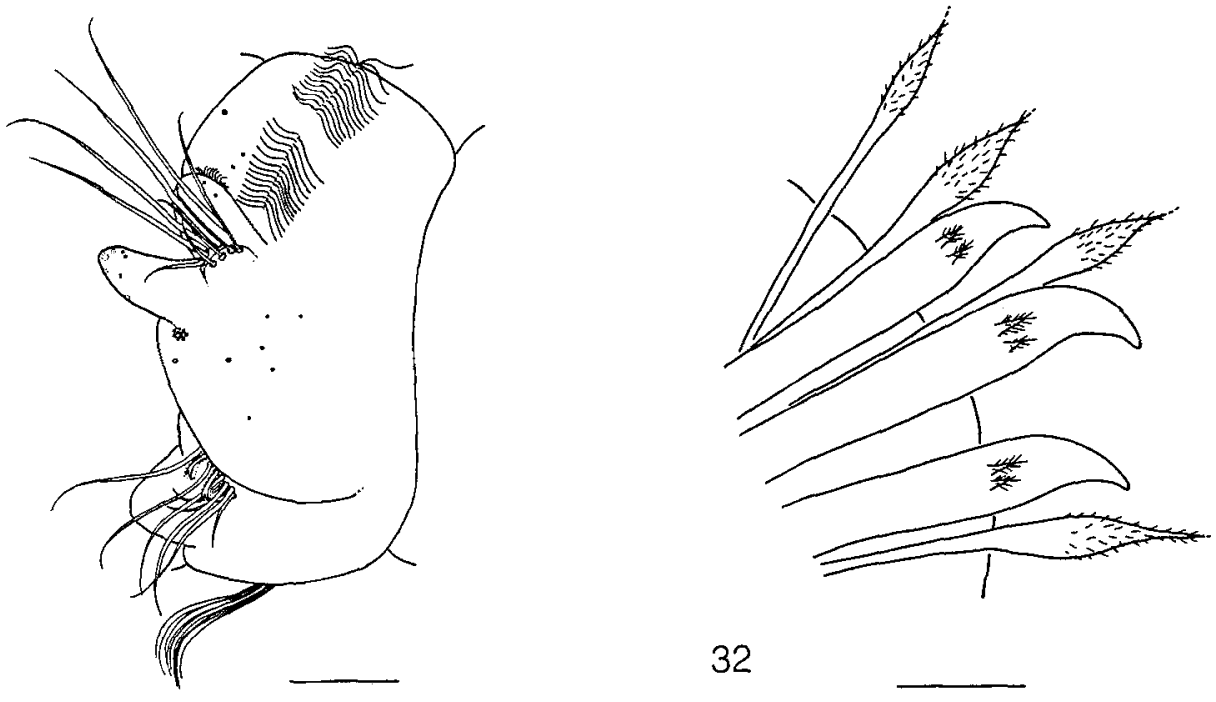

31
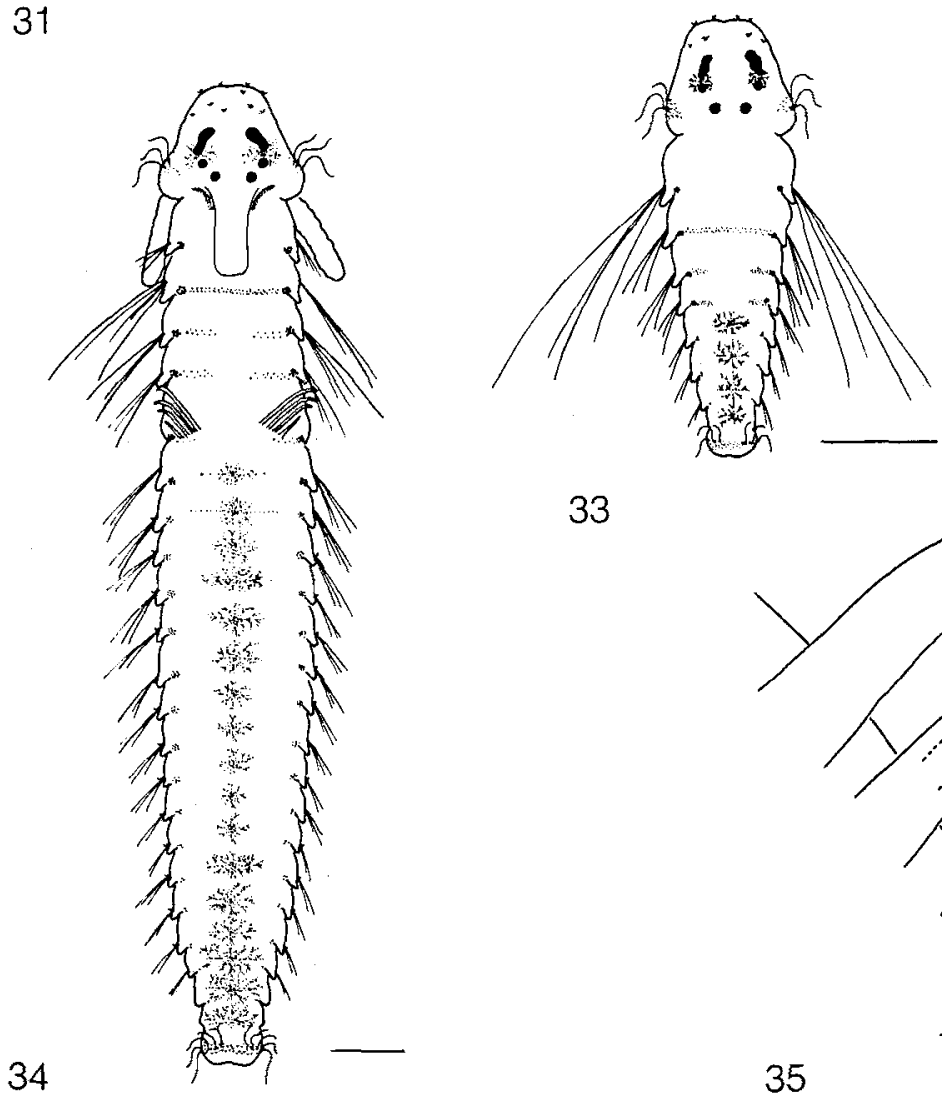

33

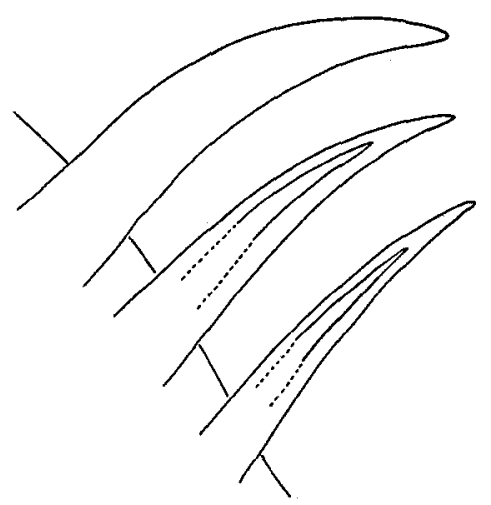




\section{Genus Pygospio \\ Pygospio elegans Claparède, 1863 (Fig. 39)}

Earliest pelagic stage has 3 setigers and a length of $\approx 320 \mu \mathrm{m}$, oldest pelagic stage with 18 setigers and $\approx 1500 \mu \mathrm{m}$. Prostomium broad with a prominent notch or rounded, long sensory cilia and 2 gland cells; 3 pairs of black eyes, the second pair often very small; prototroch well-developed; palps short and attached on the lateral parts of the peristomium; caruncle small and flat, bounded by nuchal organs; without a ciliated pit; gut with numerous yolk droplets; from segment 1 onwards dorsal melanophores in transverse bandlike arrangement; telotroch well-developed, dorsally discontinuous; pygidium broadly rounded with numerous gland cells, without anal cirri; diserrated hooded hooks from segment 8 onwards in the neuropodia; gastrotrochs in segments 5,7 and 11. Seasonal occurrence: I-VII

\section{Genus Prionospio}

Prionospio (Minuspio) cirrifera Wirén, 1883 (Figs 40-41)

Earliest planktonic stage is an egg with a length of $180 \mu \mathrm{m}$; oldest pelagic stage is a larva with 15 segments and a length of $\approx 1200 \mu \mathrm{m}$. Prostomium round to rectangular 2 pairs of red eyes; prototroch and telotroch well-developed; telotroch dorsally discontinuous; palps differentiated relatively late, attached on the lateral parts of the peristomium, with cilia in 2 systems: on the inner side of the palp, a long ciliary groove as it is seen in most spionids and numerous separated transverse bands of cilia on the outer side; prototroch located on the proximal part of the palps; small and short caruncle, reaching segment 1 , bounded by nuchal organs; ciliated pit in segment 2 ; besides some brown pigment at the pygidium and anterior to the prototroch, additional brown pigment at the proboscis in older stages, no dorsal melanophores; pygidium with numerous gland cells, 1 pair of short anal cirri in older stages; multiserrated hooded hooks in neuropodia from segment 10 or 12 onwards, larval stages without notopodial hooded hooks; gastrotrochs present from segment 4 onwards; young larval stages (approximately up to the 10-setiger stage) with a species-specific appearance: they possess a very slender second setiger which forms a waist. Seasonal occurrence: III-VII

\section{Genus Spiophanes}

Spiophanes bombyx Claparède, 1870 (Figs 42-43)

Earliest pelagic stage has 3 setigers and a length of $\approx 400 \mu \mathrm{m}_{\text {; }}$ oldest planktonic stage is an erpochaeta with 21 setigers and has a length of $\approx 2100 \mu \mathrm{m}$. Prostomium rounded, in older larval stages with lateral processes; palps remain short, attached far laterally at the peristomium; very small and inconspicuous caruncle, bounded by nuchal organs; proto- and telotroch well-developed, telotroch dorsally discontinuous; 2 pairs of red eyes, the first pair laterally situated, yellow chromatophores at the prostomium and pygidium, black pigment at the pygidium and lateral on the proboscis; a single strong and curved setae in the neuropodia of setiger 1; parapodial glands from segment 5 onwards; no ciliated pit; gastrotrochs from segment 2 onwards; diserrated hooded hooks 

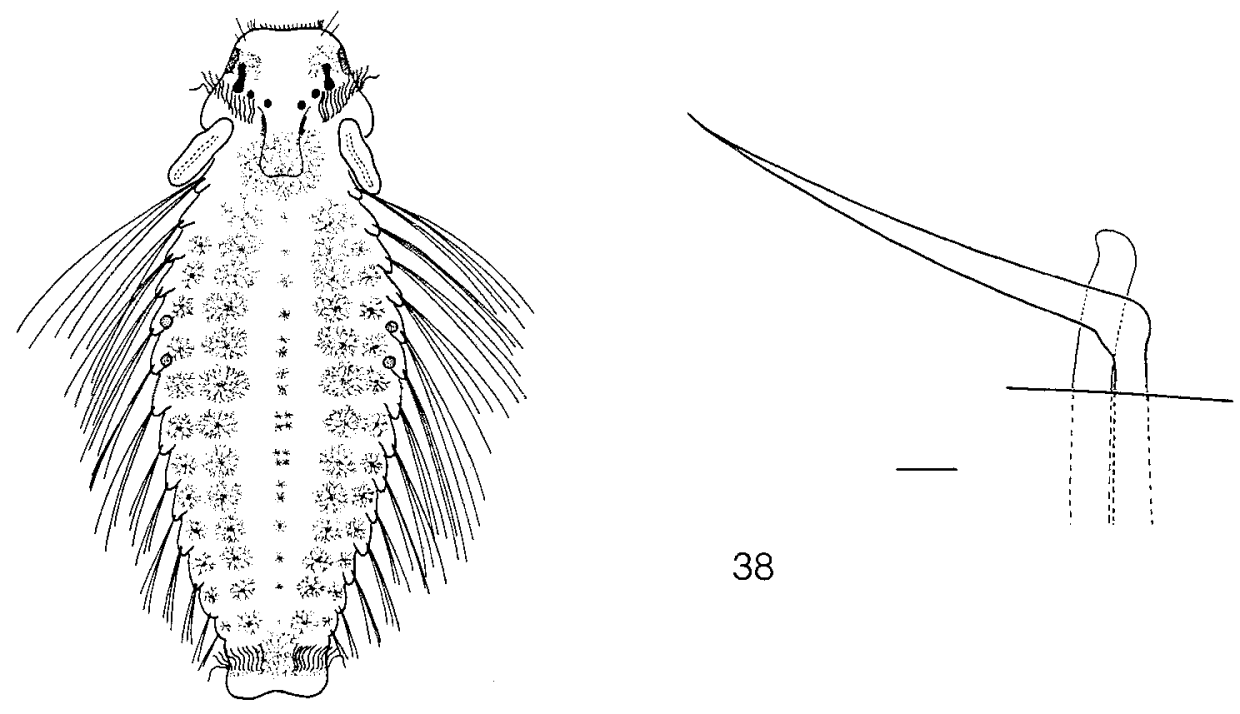

36
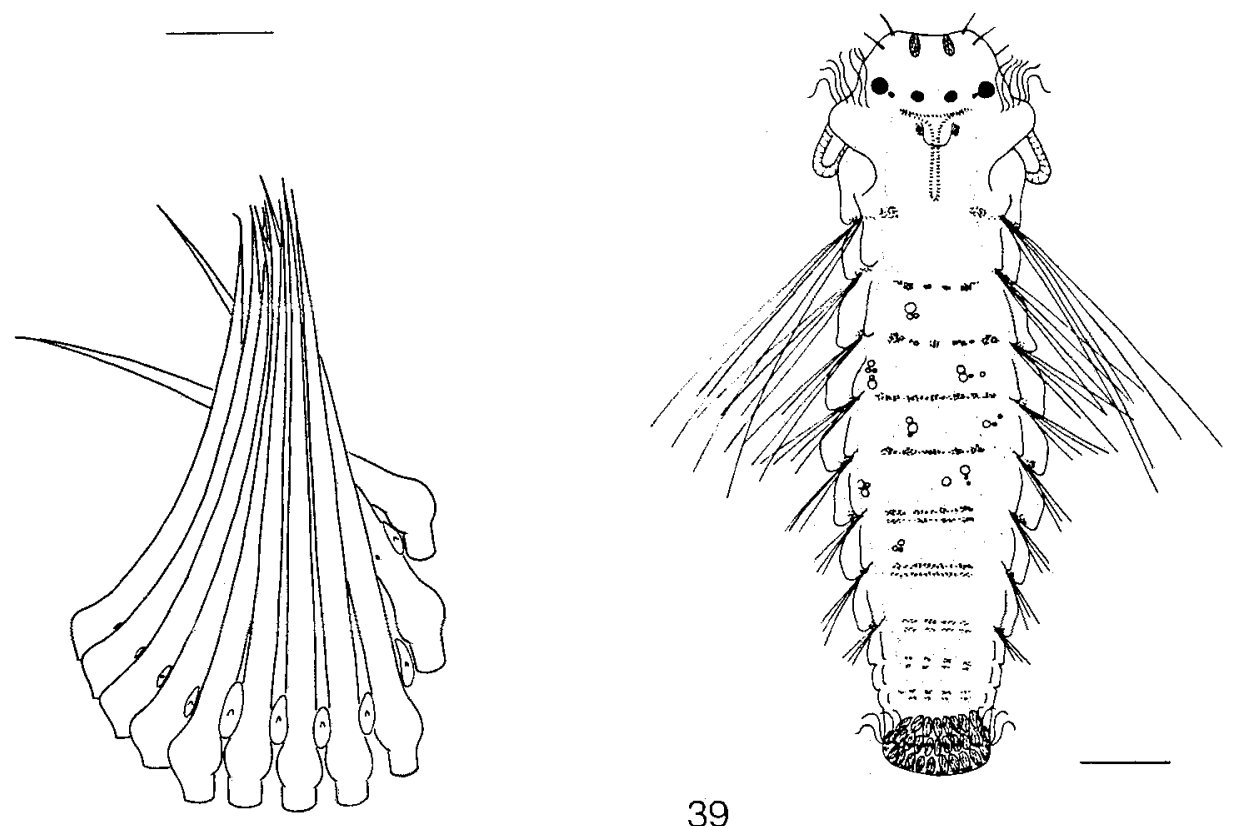

39

37

Figs 36-38. Polydora (Pseudopolydora) pulchra; 36: dorsal view of pelagic larvae with 14 segments; sulphuric-yellow chromatophores are differentiated at the peristomium and at segment 5 to $6 ; 37$ : modified setae of segment 5 arranged in a half-circle; 38: the modified setae are short, stout and accompanied by long capillary setae. Fig. 39. Pygospio elegans; planktonic larva with 11 segments, dorsal view; pygidium with many gland cells. Scale bar: $36: 200 \mu \mathrm{m} ; 37,38: 20 \mu \mathrm{m} ; 39: 100 \mu \mathrm{m}$ 
from segment 13 onwards; larval setae not especially long and lustreless; pygidium with 1 pair of anal cirri. Seasonal occurrence: III-X

\section{Genus Scolelepis}

Scolelepis (Scolelepis) squamata (Müller, 1789) (Fig. 44)

Synonym: Nerine cirratulus Fauvel (1927)

Earliest pelagic stage observed is a trochophore with 2 segment anlagen and a length of $\approx 290 \mu \mathrm{m}$; oldest pelagic stage is an erpochaeta with 33 segments and a length of $\approx 2600 \mu \mathrm{m}$. Prostomium bell-shaped, with a protractile tip, peristomium with lateral processes, carrying the well-developed prototroch; palps differentiate late and remain very short; 2 pairs of red eyes; caruncle and nuchal organs absent; vivid and speciesspecific pigmentation: prostomium orange coloured, the oesophagus is pigmented bluegreen, the gut shows brown chromatophores; gut with well-developed segmental diverticula; larval setae relatively short and lustreless, lost early; diserrated hooded hooks in noto- and neuropodia: in notopodia from segment 22 and in neuropodia from segment 18 onwards; gastrotrochs from segment 3 onwards in each segment; telotroch welldeveloped and dorsally continuous; pygidium big and knoblike, without appendages; no branchial anlagen. Seasonal occurrence: III-X

\section{Scolelepis (Scolelepis) bonnieri (Mesnil, 1896) (Fig. 45)}

Earliest planktonic stage is an ovoid, flattened egg with sculptured egg-membrane, length $360 \mu \mathrm{m}$, width $\approx 280 \mu \mathrm{m}$; oldest planktonic stage is a larva with 19 segments and a length of $\approx 1900 \mu \mathrm{m}$. Eggs and trochophores are totally opaque and light-brown pigmented; trochophore with apical tuft, proto- and telotroch; from the 3-segment stage onwards having 2 pairs of red eyes; prostomium trapezoid with a protractile tip; palps always short, attached to the lateral part of the peristomium; caruncle and nuchal organs absent; proto- and telotroch well-developed, telotroch dorsally continuous; pygidium broad and rounded with a slight notch, without appendages; diserrated hooded hooks in noto- and neuropodia - in notopodia from segment 17 and in neuropodia from segment 18 onwards; gastrotrochs from segment 2 onwards; body weakly pigmented: speciesspecific red chromatophores lateral at the dorsum from segment 2 onwards, light-brown pigment at the prostomium and pygidium, sometimes dark-brown pigmentation on the lateral part of proboscis; gut with segmental diverticula; besides larval setae, some strong, unserrated and curved capillary setae from segment 7 onwards which persist to the adult stage; larval stages with more than 10 setigers show branchia anlagen from segment 2 onwards. Seasonal occurrence: I-VIII

Figs 40-41. Prionospio (Minuspio) cirrifera; 40: young pelagic larva with 10 segments; 41 : planktonic larva comprising 15 segments; the palps with cilia in two systems. Figs $42-43$. Spiophanes bombyx; 42: anterior segments of a larva ready to metamorphose; from segment 5 onwards parapodial glands are developed; 43: species specific, strong and curved setae in the neuropodia of segment 1. Scale bar: $40-42: 100 \mu \mathrm{m}_{\text {; }} 43: 10 \mu \mathrm{m}$ 


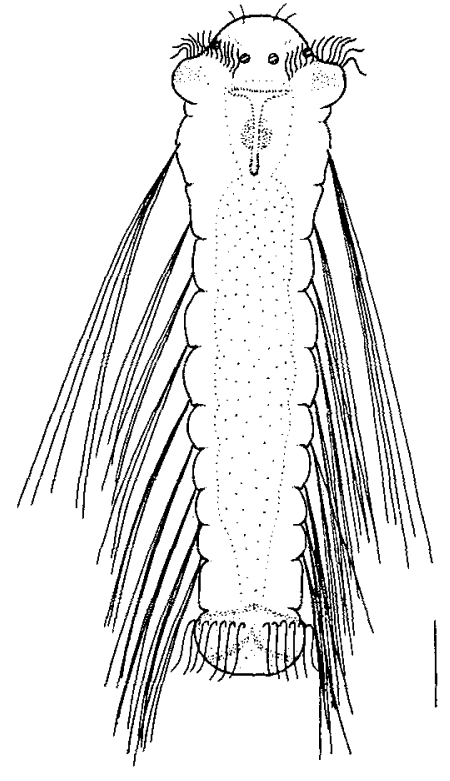

40

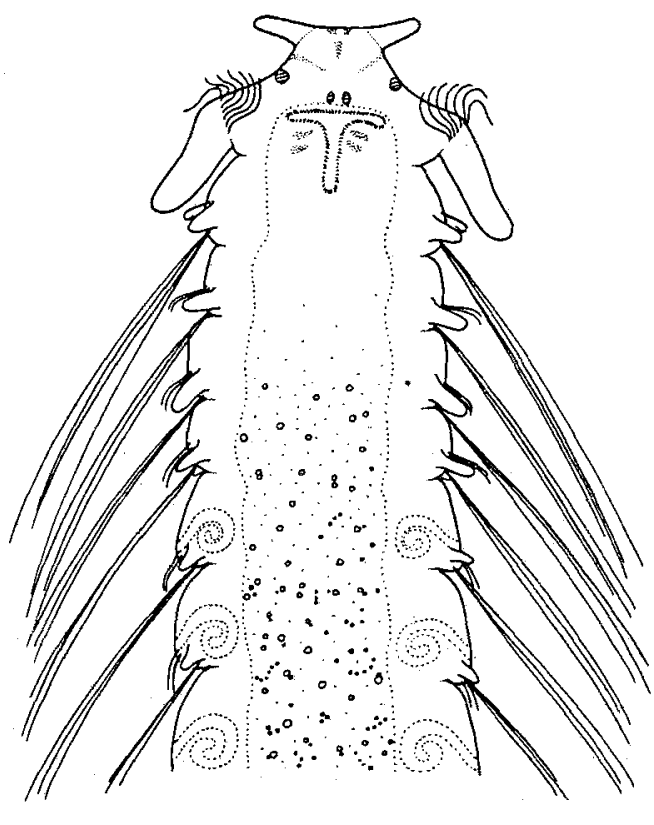

42
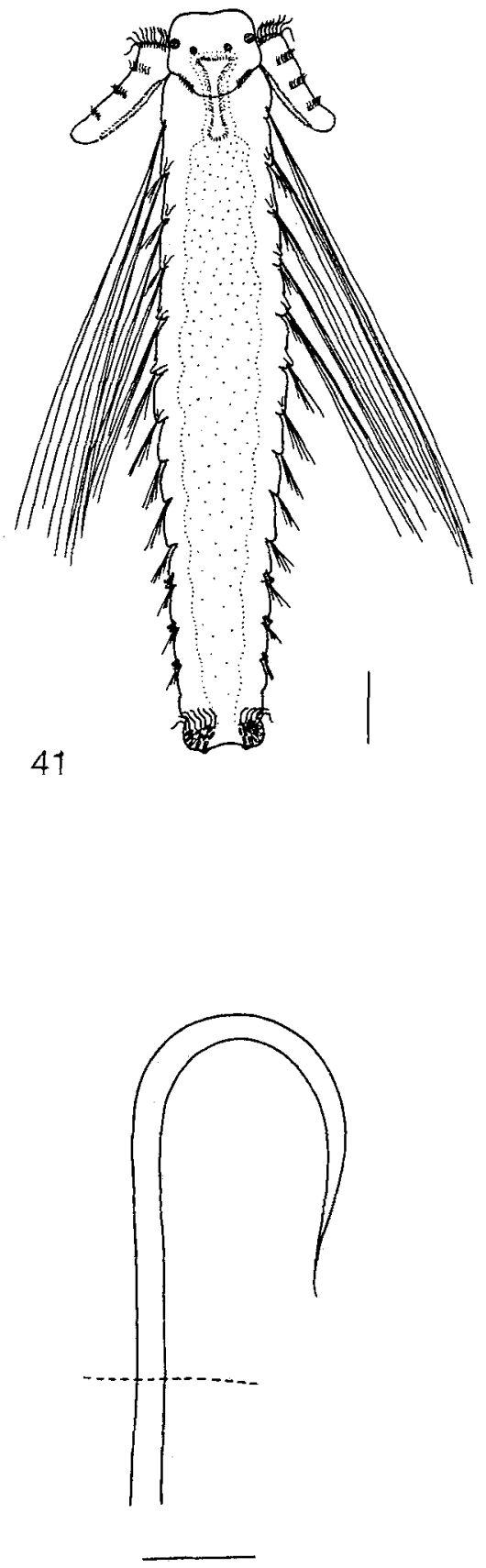

43 
Scolelepis sp. (Fig. 46)

Earliest planktonic stage is a larva with 4 segments and has a length of $\approx 320 \mu \mathrm{m}$; oldest pelagic stage is a 20 -setiger stage with a length of $\approx 1200 \mu \mathrm{m}$. Prostomium broadly rounded with an anterior tip, with sensory cilia and a pair of gland cells which are in contact with the epidermis; peristomium with lateral processes, carrying the welldeveloped prototroch; palps remain undeveloped, even in older stages; little, transversely oriented nuchal organs posterior to the prototroch; caruncle absent; oesophagus dark-brown pigmented, reaching segment 2, gut black pigmented without marked diverticula, proctodeum unpigmented; pygidium rounded with a slight notch, in older larval stages with 2 or 4 anal cirri; telotroch dorsally continuous; tiny ciliated pit in segment 2; gastrotrochs from segment 4 onwards; parapodia anlagen remain undeveloped; all larval stages without branchia anlagen: diserrated hooded hooks from segment 18 onwards, only in neuropodia are these developed. Seasonal occurrence: VII-X

Taxonomic note: Hannerz (1956) found larvae of this type (Nerine sp. I) in the plankton of the Gulmar Fjord, Sweden. The larvae were recorded for the first time in the German Bight (Plate, 1992). Adult individuals are unknown.

\section{Genus Malacoceros}

Malacoceros (Malacoceros) fuliginosus (Claparède, 1868) (Figs 47-48)

Synonyms: Scolelepis fuliginosa (Claparède, 1869) Nerine fuliginosa (Söderström, 1920)

Earliest planktonic stage is an uncleaved egg with a length of $190 \mu \mathrm{m}$ and a width of $150 \mu \mathrm{m}$. Egg membrane is thick and sculptured; trochophores with proto- and telotroch, apical tuft present; larvae at the 2-setiger stage possess up to 3 pairs of red eyes, the red colour changes with further development into black; oldest pelagic larvae with 14 segments and a length of $\approx 750 \mu \mathrm{m}$. Prostomium broad and rectangular; peristomium with lateral processes bearing the well-developed palps; palps reaching segment 4 ; prototroch well-developed $d_{i}$ flat and short caruncle, bounded by small nuchal organs; larvae without dorsal pigmentation; parapodia well-developed, with prominent dorsal cirrus, dorsal cirrus in segment 3 often dark-brown pigmented; larval setae not very long but strong; ciliated pit in segment 2; gastrotrochs in segments $3,5,7$, and 9 ; diserrated hooded hooks in neuropodia from segment 8 or in all segments from segment 3 onwards; pygidium rounded and brown pigmented, with numerous gland cells, without appendages; telotroch well-developed, dorsally discontinuous. Seasonal occurrence: II-IX

Fig. 44. Scolelepis (Scolelepis) squamata; dorsal view of a pelagic larva with 12 segments; larva with vivid species-specific pigmentation: Prostomium orange, oesophagus blue-green, gut brown. Fig. 45. Scolelepis (Scolelepis) bonnieri; young planktonic larva with 4 segments. Fig. 46: Scolelepis sp.; dorsal view of a pelagic stage with 7 segments: oesophagus with brown chromatophores, gut black pigmented. Scale bar: $44: 200 \mu \mathrm{m}_{\mathrm{i}} 45,46: 100 \mu \mathrm{m}$ 


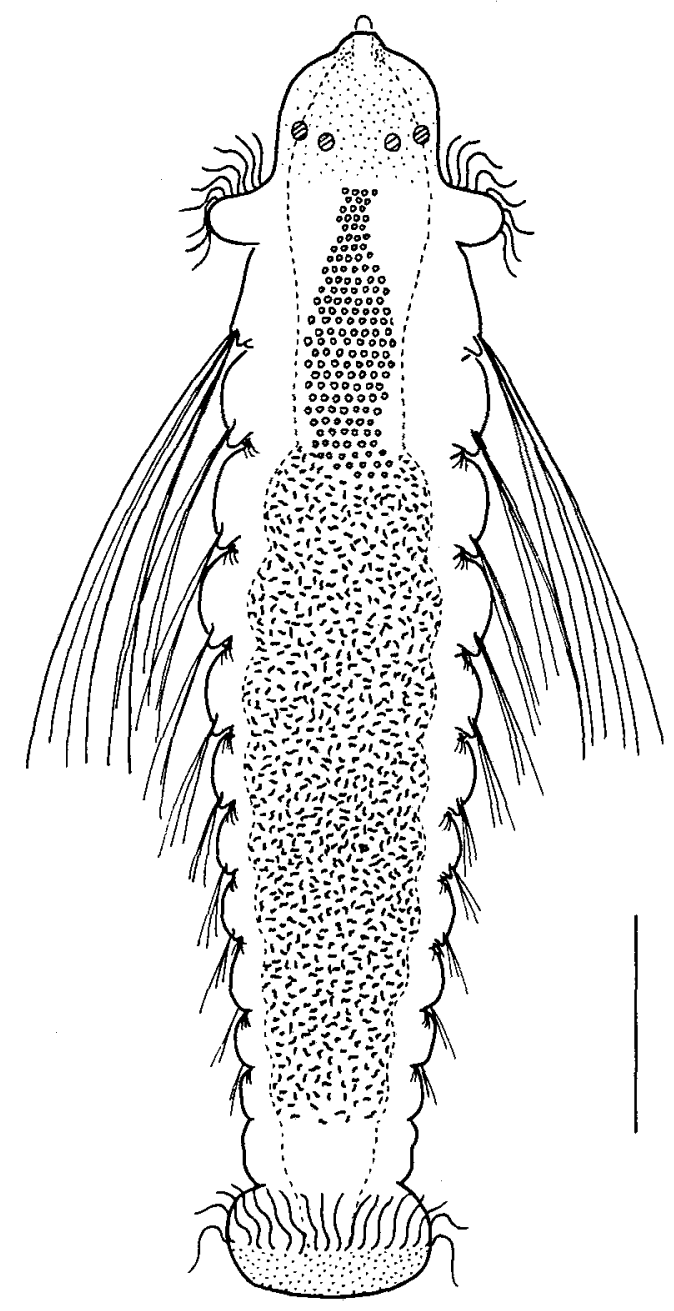

44
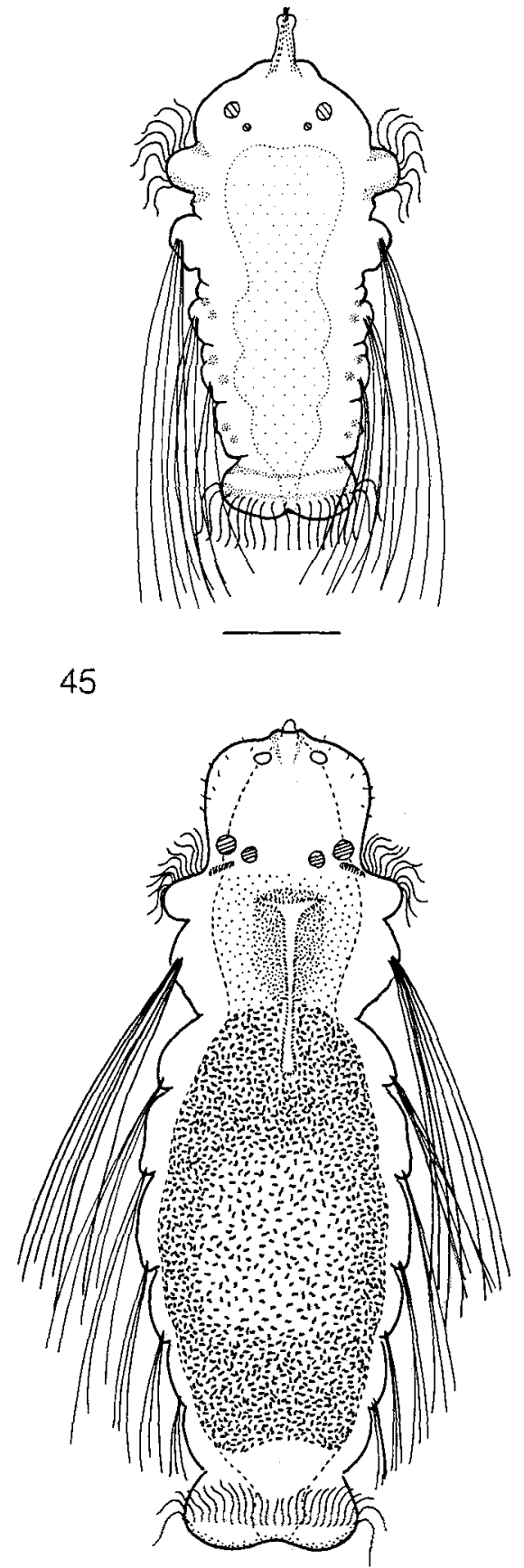


\section{Poecilochaetidae}

\section{Genus Poecilochaetus}

Poecilochaetus serpens (Allen, 1904) (Figs 49-50)

The early development of Poecilochaetus serpens is unknown, but it is considered entirely pelagic. The later part of the pelagic development is divided into 2 stages. The first stage is the metatrochophore stage, in which the larvae are provided with proto-, telo- and gastrotrochs used for movement and with provisional setae. Larvae remain in the metatrochophore stage until 30-38 setigers are developed. The second stage is the nectosoma stage in which the trochs are reduced and locomotion takes place in a snakelike manner.

Earliest observed planktonic stage is a metatrochophore with 10 setigers; oldest pelagic stage is a nectosoma with 44 setigers. The metatrochophore has a transparent body; apart from sulphuric-yellow chromatophores at the "head" and pygidium, it is unpigmented. There is a well-developed proto- and telotroch; gastrotrochs in all segments from the first onwards; with sensory cilia at the prostomium, a small caruncle bounded with nuchal organs; without palps at the peristomium; ciliated pit in segment 2; parapodia weakly developed; larval setae very thin, additional strong and relatively short capillary setae which persist in the adult; pygidium small, without anal cirri; body very long and slender with a length up to $\approx 4500 \mu \mathrm{m}$. Nectosoma with palps at the peristomium; caruncle extends to a long and slender nuchal tentacle; well-developed parapodia; body with 3 regions; thorax from segment 1-6, with parapodia comprising cirriform dorsal and ventral postsetal lobes and spherical lateral organs between the postsetal lobes; middle body region from segment $7-13$, with parapodia comprising prominent bottle-shaped postsetal lobes; abdominal body region from segment 14 onwards; pygidium with 2 pairs of anal cirri; the pigmentation remains unchanged; body extremely long and slender; oldest observed larvae with 44 setigers and a length of $\approx 5000 \mu \mathrm{m}$. Seasonal occurrence: III-VIII

\section{Sabellariidae}

\section{Genus Sabellaria}

Sabellaria spinulosa Leuckart, 1849 (Fig. 51)

Earliest pelagic stage is a trochophore; oldest stage is a metatrochophore with 7 segments and a length of $650 \mu \mathrm{m}$. Trochophores are spherical with 2 red eyes, prototroch and telotroch present; in older stages long, strong and annulated larval setae appearing laterally on both sides of the hyposphere. Prostomium rounded in metatrochophores; 2 pairs of red eyes; parapodia biramous; dorsally located band-shaped melanophores in each segment. Larvae weakly coloured with some brown chromatophores distributed

Figs 47-48. Malacoceros (Malacoceros) fuliginosus; 47: planktonic trochophore stage surrounded by an egg membrane; 48: dorsal view of a pelagic larva ready to metamorphose. Figs 49-50. Poecilochaetus serpens; 49: dorsal view of a late metatrochophore stage; 50: segment of the middle body region of a metatrochophore stage. Scale bar: $47,48,50: 100 \mu \mathrm{m} ; 49: 500 \mu \mathrm{m}$ 


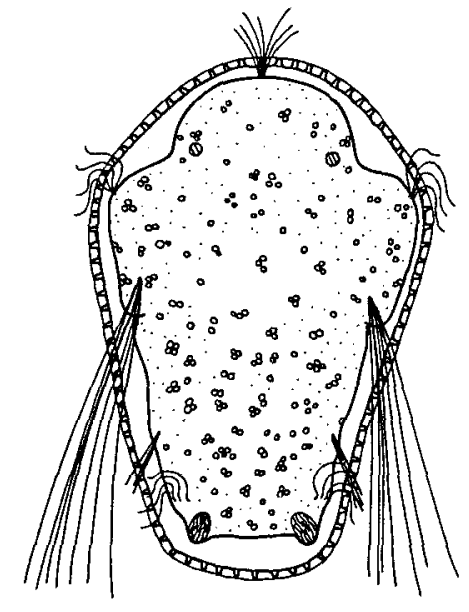

47
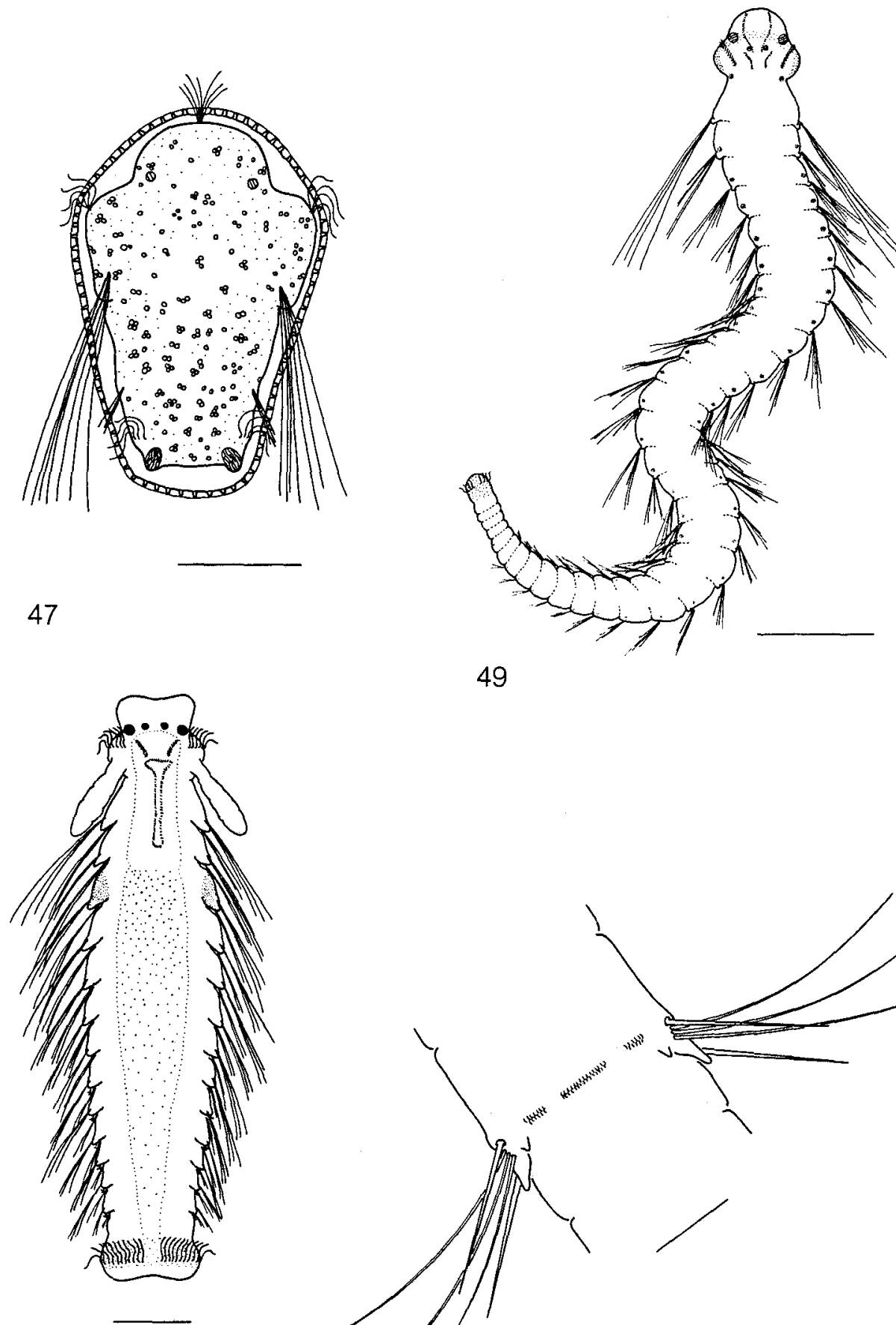

49

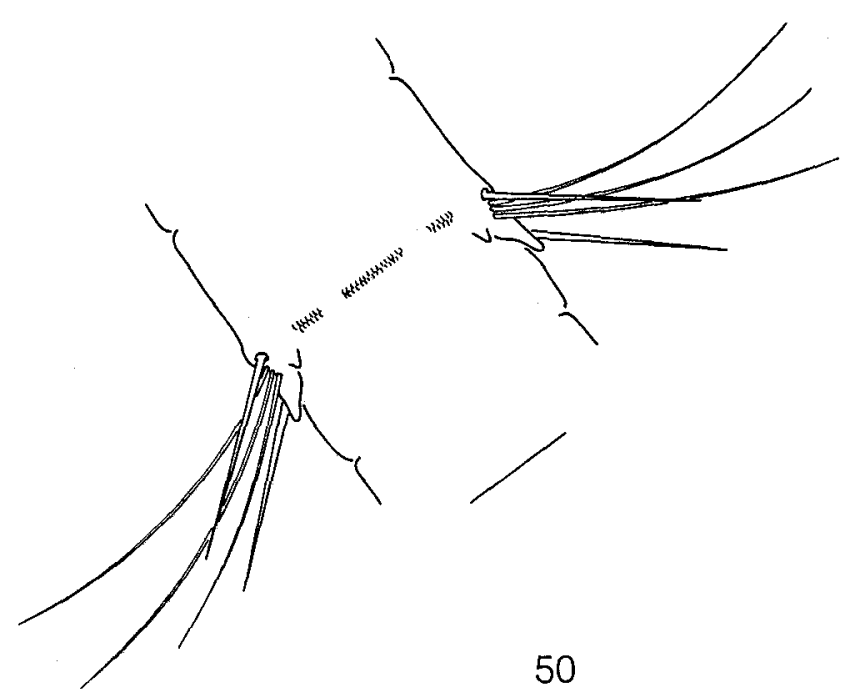

48 
over the whole body and pale brown gut. Tentacular cirri, antennae and paddlelike, serrated primary crown-paleae do not occur until larvae become benthic. Seasonal occurrence: V-X

\section{Pectinariidae}

The genus and species determination of larvae in the family Pectinariidae is not possible with certainty, due to the very weak morphological differences. Therefore, only a general description of the typical larval features is given below (Figs 52-53).

In the German Bight, only Amphictene auricoma O. F. Müller, 1776 and Lagis koreni Malmgren, 1865 have been observed during benthos investigations (Rachor \& Gerlach, 1978; Salzwedel et al., 1985; Hickel et al., 1989). The observed larvae probably belong to one of these two species.

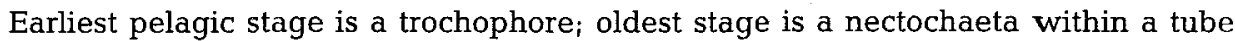
comprising 16 setigers. Trochophores are pear-shaped, with 1 pair of red eyes, prototroch and telotroch. Metatrochophores possess retractible prototrochal lobes; 14-16 segment anlagen; paleae in setal sacs within the body located in the anteriormost segments; ventral, median ciliary band between the proto- and telotroch; red chromatophores distributed over the whole body, at the prostomium and median in every segment forming a transverse row; gut dark-brown coloured. Nectochaetae within a tube, which may sometimes be lost; prostomium round with 2 red eyes; 1 pair of palpi; paleae outside the body, surrounding the prostomium; 2 pairs of tentacular cirri; parapodia biramous; notopodia with simple, spiniger setae; neuropodia with uncini; pygidium separated from the trunk, with scaphe; all trochs reduced. Seasonal occurrence: IV-IX

\section{Goniadidae}

\section{Genus Goniadella}

Goniadella bobretzkii (Annenkova, 1929) (Fig. 54)

Earliest pelagic stage is a trochophore; oldest stage is a metatrochophore with 11 segment anlagen and a length of $480 \mu \mathrm{m}$. Trochophores are elongated oval and light brown pigmented; episphere with 1 pair of red eyes; acrotroch present; prototroch, consisting of 2 separate ciliary rows; gut with many yolk granules. Metatrochophores and nectochaetae with 11-14 segments; prostomium long, tapering, in older stages annulated (7-8 rings) with 4 antennae at the apical end; 2 pairs of red eyes, 1 pair at the subdistal and 1 pair at the proximal ring of the prostomium; parapodia uniramous with compound, falciger and uniserrated setae, dorsal and ventral cirrus as well as a developed presetal lobe; anal cirri tapering; interpodial ciliary bands from segment 10 onwards. Proboscis with papillae and chevrons lateral on both sides visible in late erpochaeta stage. Seasonal occurrence: VIII-IX

Fig. 51. Sabellaria spinulosa; dorsal view of a late metatrochophore stage. Figs 52-53. Pectinariidae; 52: lateral view of a metatrochophore with protruded prototrochal lobe; 53: dorsal view of a nectochaeta within tube. Scale bar: $51,52: 100 \mu \mathrm{m} ; 53: 200 \mu \mathrm{m}$ (51 after Wilson, 1929) 


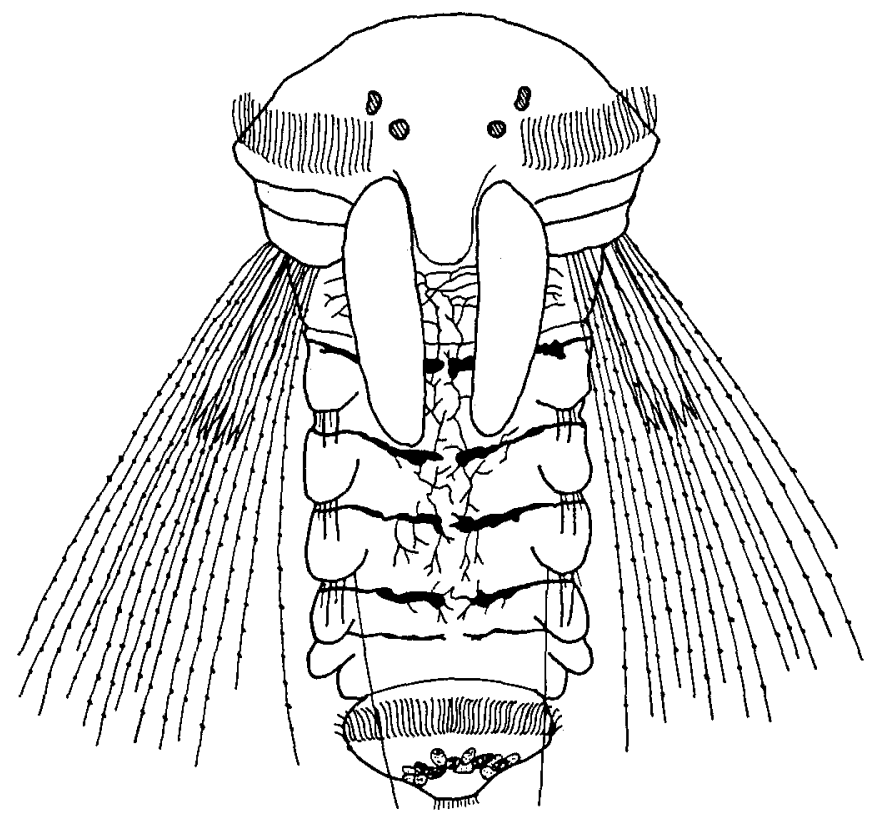

51
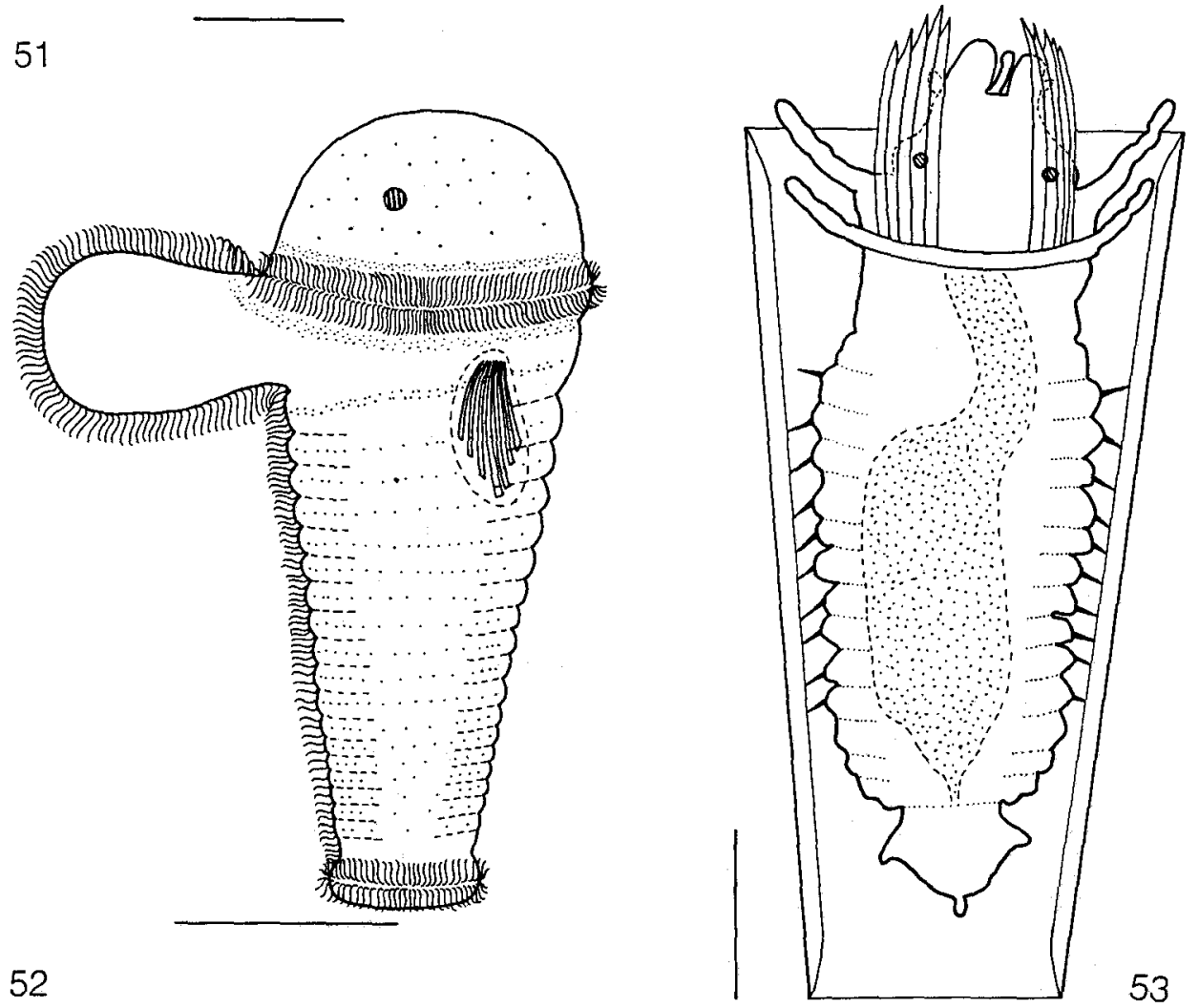


\section{Genus Goniada}

\section{Goniada maculata Ørsted, 1843 (Figs 55-56)}

Only stages found in the plankton are spherical, nearly transparent trochophores with a diameter of $200-300 \mu \mathrm{m}$. Trochophores have a well-developed prototroch; eyes absent; gut with yolk granules; few green pigments at the prototroch. Metatrochophores and nectochaetae with 4-5 segments; prostomium long, tapering, in older stages annulated (9-10 rings) with 4 antennae at the tip; no eyes; gastrotrochs in posterior segments; pygidium with telotroch and 2 tapering anal cirri. Parapodia uniramous with compound, falciger, uniserrated setae and acicula; dorsal and ventral cirrus as well as a presetal lobe differentiated; interpodial ciliary bands from segment 4 onwards; pigmentation weak, light brown with darker areas at the pygidium. Proboscis with papillae and chevrons lateral on both sides visible in late erpochaeta stage. Seasonal occurrence: XI-II

\section{Glyceridae}

\section{Genus Glycera}

\section{Glycera capitata Ørsted, 1845 (Figs 57-58)}

Trochophores with a diameter of $300-350 \mu \mathrm{m}$ are the only observed stages in the plankton. They are spherical and unpigmented, with well-developed prototroch; gut with numerous yolk granules. In metatrochophores and nectochaetae, the prostomium is elongated, conical, annulated (6-8 rings), with 4 short antennae at the tip; all stages are without eyes; parapodia of segment 1 and 2 are reduced and uniramous, remaining parapodia biramous with presetal and postsetal lobes, ventral cirrus present ${ }_{i}$ simple spiniger setae in notopodia; compound falciger setae and 1 additional simple spiniger setae in neuropodia; 2 tapering anal cirri. Larvae nearly transparent with a few red chromatophores near the prototroch. The proboscis with 4 jaws differentiates in the late erpochaeta stage. Seasonal occurrence: IX-X

\section{Phyllodocidae}

\section{Genus Eteone}

Eteone longa (Fabricius, 1780) (Fig. 59)

Earliest pelagic stage is a trochophore; latest stage is a nectochaeta with 7 segments and a length of $630 \mu \mathrm{m}$. Trochophores are oval; episphere dome-shaped with 1 pair of red eyes; prototroch well-developed; gut with yolk granules. Late metatrochophore and nectochaeta stages with truncated, conical prostomium; 4 antennae; 2 pairs of red eyes of which the anterior pair is much larger then the posterior pair; telotroch present; 2 pairs of

Fig. 54. Goniadella bobretzkii; dorsal view of an erpochaeta with 14 segments. Figs 55-56. Goniada maculata; 55 : dorsal view of an erpochaeta with 5 segments; 56: compound, falciger and uniserrated setae of a median segment. Figs 57-58. Glycera capitata; 57: dorsal view of an erpochaeta with 9 segments; 58 : compound, falciger setae of a median segment. Scale bar: $54: 500 \mu \mathrm{m}_{i} 55,57: 100 \mu \mathrm{m}_{\text {; }}$ 56, 58: $20 \mu \mathrm{m}$ 

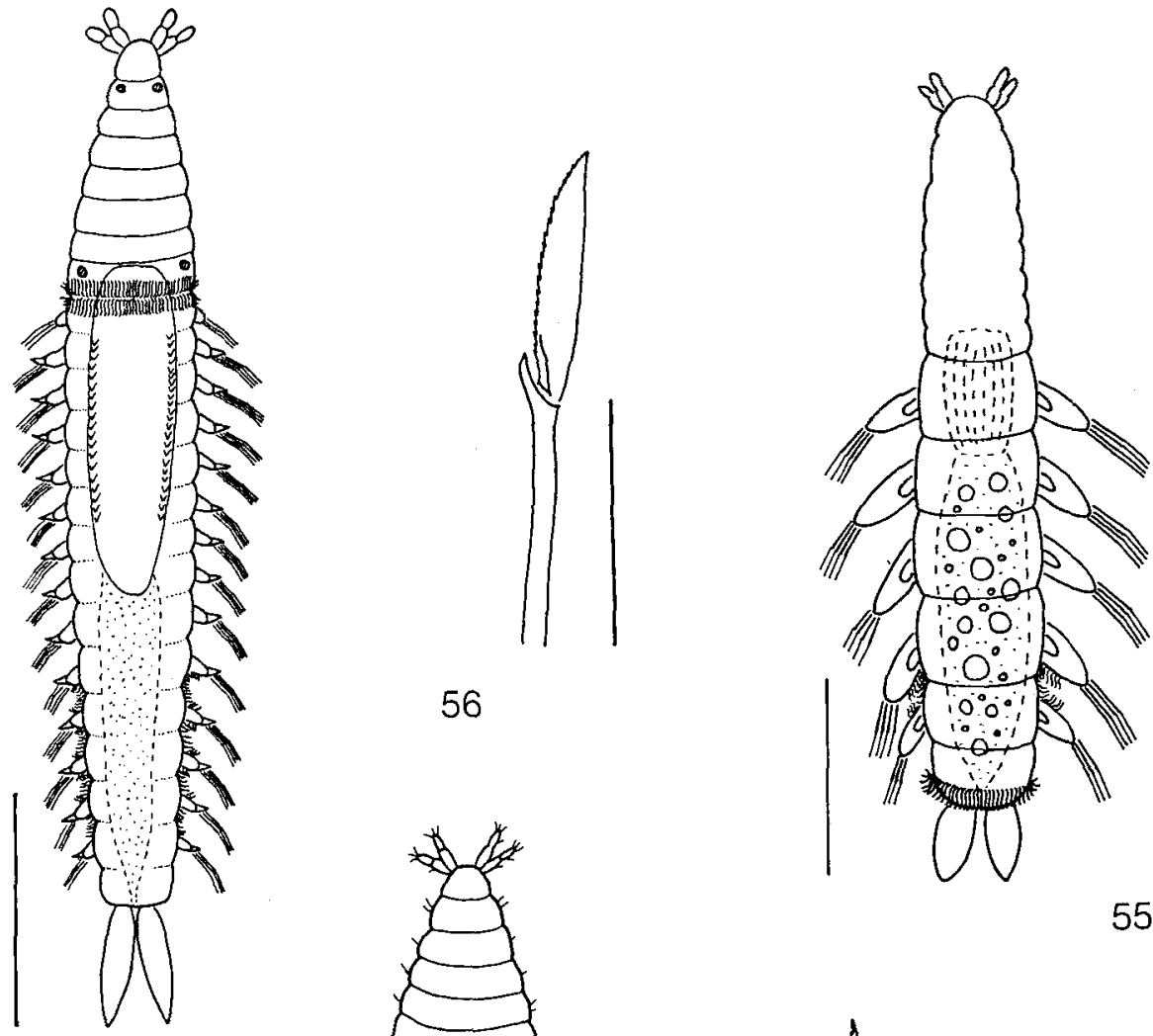

54

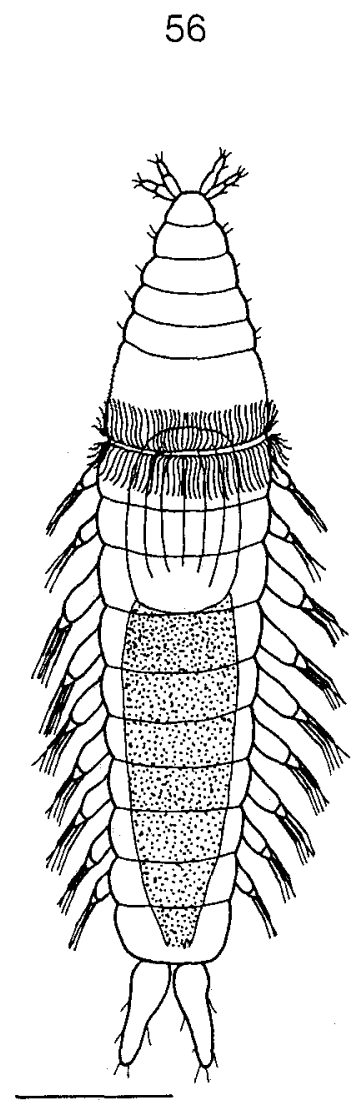

57

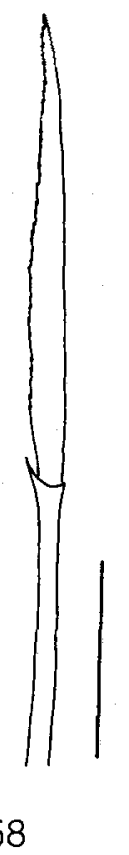


tentacular cirri of equal length in segment 1; setae and ventral cirri from segment 2 and dorsal cirri from segment 3 onwards; anal cirri short, oval. Proboscis is visible in late nectochaeta stage. Larvae brown coloured with green and brown chromatophores distributed over the whole body; highest density of chromatophores in a median line at the prostomium and at the pygidium. Seasonal occurrence: II-IV

\section{Genus Mysta}

Mysta barbata Malmgren, 1865 (Fig. 60)

Synonym Eteone barbata (Malmgren, 1865)

Only stage found in the plankton is a metatrochophore with 6 segments and a length of $400 \mu \mathrm{m}$. Late metatrochophore and nectochaeta stages with truncated conical prostomium; 4 antennae; 1 pair of dark-red eyes; well-developed prototroch; telotroch present; 2 pairs of tentacular cirri in segment 1 ; setae and ventral cirri from segment 2 and dorsal cirri from segment 3 onwards; anal cirri elongated, oval. Dorsal tentacular cirri become 1.5 times as long as the ventral cirri in the late nectochaeta stage. Larvae olivebrown pigmented with darker brown pygidium. Seasonal occurrence: IX

\section{Genus Pseudomystides}

Pseudomystides limbata (Saint-Joseph, 1888) (Fig. 61)

Synonym: Mystides (Mesomystides) limbata Saint-Joseph, 1888

Earliest planktonic stage is a trochophore; latest stage is a metatrochophore with 7 segments and a length of $460 \mu \mathrm{m}$. Trochophores are oval; round episphere, dome-shaped with 1 pair of red eyes; prototroch consists of long cilia; gut with yolk granules. Metatrochophores and nectochaetae with truncated, rectangular prostomium; 4 antennae; 2 pairs of red eyes; 1 pair of tentacular cirri in segment 1 and 2 pairs in segment 2 ; ventral tentacular cirri of segment 2 are flat with proximal broadening, remaining tentacular cirri cirriform; setae from segment 2 , ventral cirri from segment 3 and dorsal cirri from segment 4 onwards; anal cirri oval, twice as long as broad; median pygidial papilla present. All larval stages brown pigmented with a dark-brown pygidium. Ventral tentacular cirri in segment 2 become flattened in older stages, while the others remain cirriform. Proboscis with papillae visible in late nectochaeta stage. After becoming benthic, 1 small median antenna appears between the eyes in some individuals. Seasonal occurrence: VI-VIII

\section{Genus Eulalia}

Eulalia viridis (Linné, 1767) (Fig. 62)

Earliest planktonic stage is a trochophore; latest stage is a metatrochophore with 6 segments and a length of $350 \mu \mathrm{m}$. Trochophores are oval; episphere trapezoid, with 1 pair

Fig. 59. Eteone longa; dorsal view of a nectochaeta with 5 segments, 6th segment in formation. Fig. 60. Mysta barbata; dorsal view of a nectochaeta with 6 segments. Fig. 61. Pseudomystides limbata; dorsal view of an early nectochaeta with 6 segments. Fig. 62. Eulalia viridis; dorsal view of a nectochaeta with 7 segments. Scale bar: $100 \mu \mathrm{m}$ 


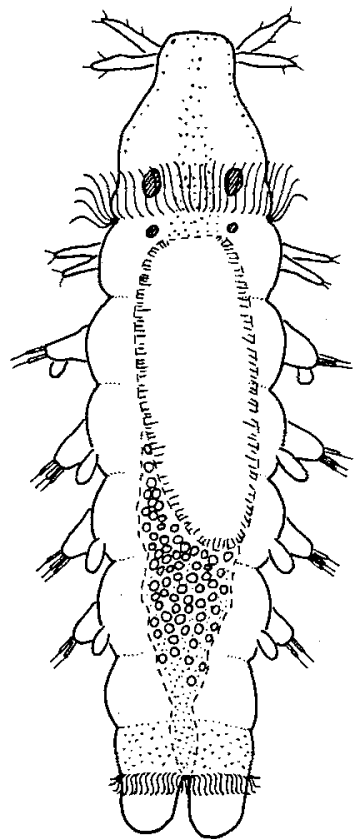

59

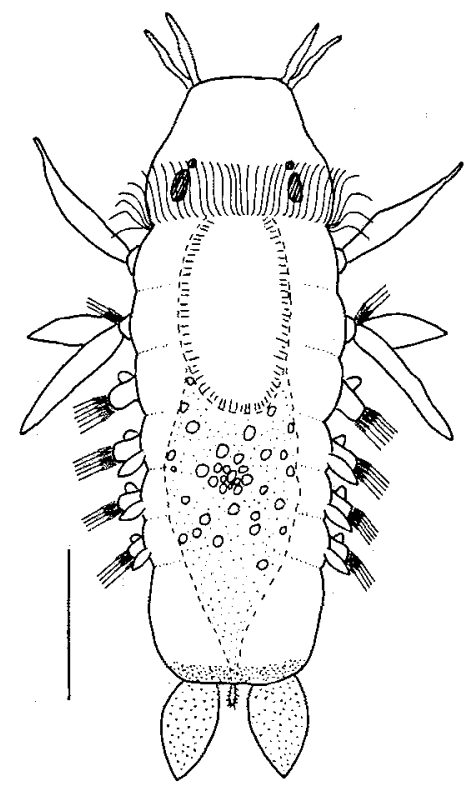

61

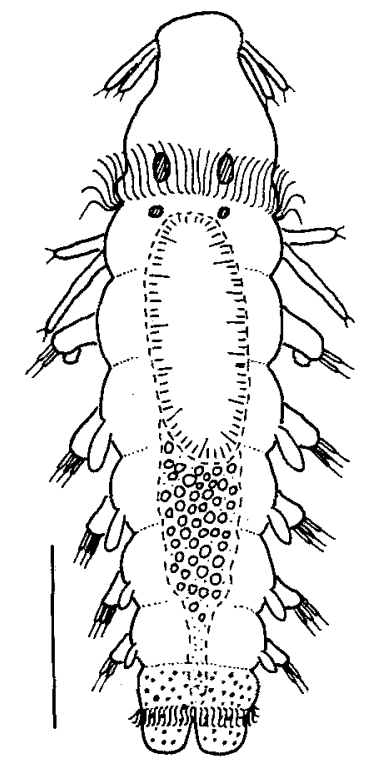

60

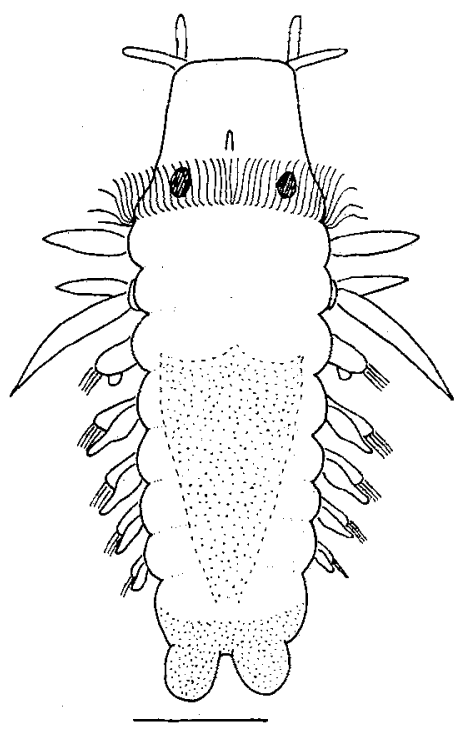

62 
of red eyes; prototroch consists of long cilia. Metatrochophores and nectochaetae with rectangular prostomium; 4 antennae; 1 pair of red eyes; 1 pair of cirriform tentacular cirri in segment 1 and 2 pairs in segment 2; setae occur from segment 2 onwards, ventral cirri occur from segment 3 onwards and dorsal cirri are present from segment 4 onwards; 1 pair of rounded anal cirri. One median antenna arises in the late nectochaeta stage anterior to the eyes. Larvae slightly coloured with olive-brown to dark-green gut and olive-brown pigmented pygidium. A 4th pair of tentacular cirri appears in segment 3 in benthic juveniles comprising about 19 segments. Seasonal occurrence: IV-VI

\section{Genus Eumida}

Eumida sanguinea (Ørsted, 1843) (Fig. 63)

Synonym: Eulalia sanguinea Ørsted, 1843

Earliest planktonic stage is a trochophore; latest stage is a nectochaeta with 14 segments and a length of $1100 \mu \mathrm{m}$. Trochophores are oval, greenish coloured with yellow-white pigment spots arranged in a ring posterior to the prototroch. Metatrochophores and nectochaetae with conical, dome-shaped prostomium; 4 antennae; 2 pairs of red eyes; prototroch present; 1 pair of cirriform tentacular cirri in segment 1 and 2 pairs in segment 2 ; setae present from segment 2 onwards, ventral cirri occur from segment 3 onwards, and dorsal cirri are found from segment 4 onwards. One pair of slender, tapering anal cirri. Larval body greenish coloured with yellow-white pigment posterior to the prototroch and dark brown gut. Proboscis with a ring of distally located papillae, first differentiated in the late metatrochophore stage. One median antenna appears in late nectochaeta stage, when the larvae become benthic. A 4 th pair of tentacular cirri originates in segment 3 in late erpochaeta stage. Seasonal occurrence: VI-XII

\section{Genus Sige}

Sige fusigera Malmgren, 1865 (Fig. 64)

Earliest pelagic stage is a trochophore; latest stage is a metatrochophore with 7 segments and a length of $400 \mu \mathrm{m}$. Trochophores are oval; episphere dome-shaped with 1 pair of red eyes; prototroch with long cilia; gut dark-brown coloured. Metatrochophores and nectochaetae with rounded, triangular prostomium; 4 antennae; 1 pair of large, red eyes; 1 pair of cirriform tentacular cirri in segment 1 ; ventral tentacular cirri of segment 2 \pm flat and proximally broadening, dorsal tentacular cirri cirriform; setae from segment 2 , ventral cirri present from segment 3 onwards and dorsal cirri occur from segment 4 onwards. One pair of slender, tapering anal cirri. Larvae weakly pigmented, with darkbrown coloured gut. Nectochaetae with 1 median antenna between the eyes; proboscis with a ring of distally located papillae; small median anal papilla. A 4 th pair of tentacular

Fig. 63. Eumida sanguinea; late nectochaeta with 9 segments, dorsal view. Fig. 64. Sige fusigera; erpochaeta with 7 segments, dorsal view. Figs 65-66. Phyllodoce rosea; 65: dorsal view of a late metatrochophore with 17 segments; 66: lateral view of a parapodium of a median segment. Scale bar: $63,65: 200 \mu \mathrm{m} ; 64: 100 \mu \mathrm{m} ; 66: 20 \mu \mathrm{m}$ 


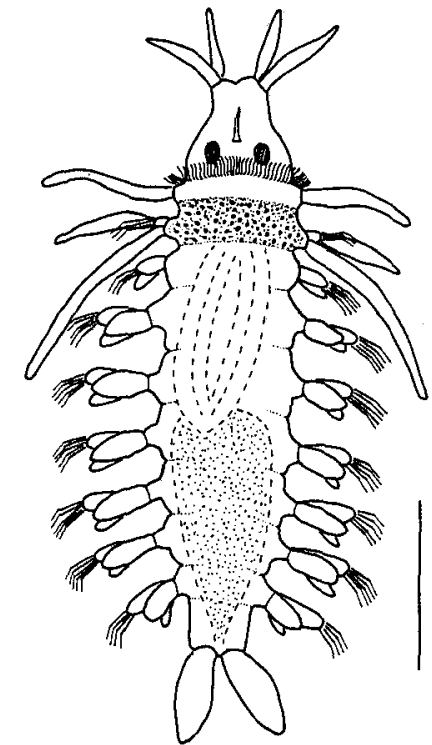

63

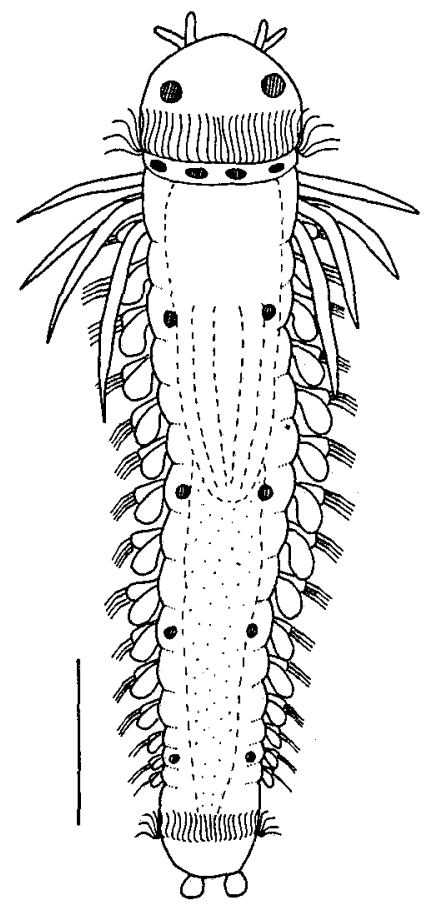

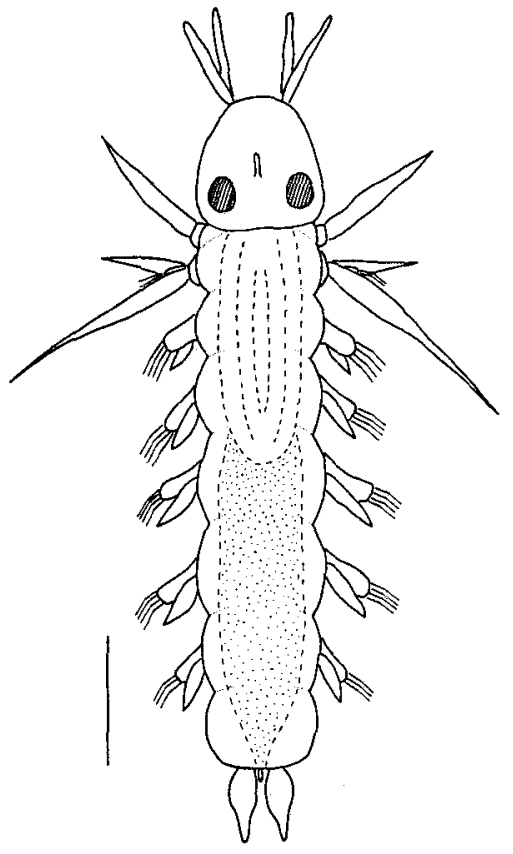

64

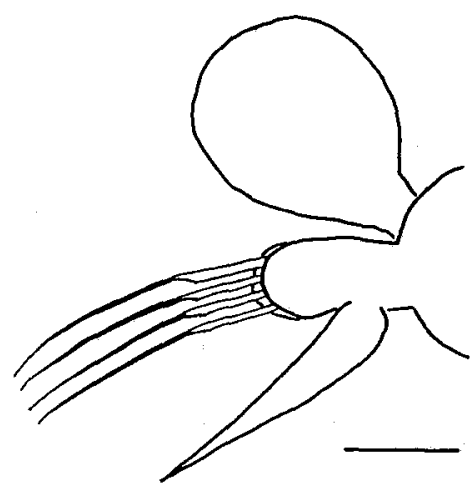

66 
cirri originating in segment 3 becomes visible at the earliest in benthic juveniles with 9 segments. Seasonal occurrence: IX-XI

\section{Genus Phyllodoce}

Phyllodoce rosea (McIntosh, 1877) (Figs 65-66)

Synonym: Anaitides subulifera Eliason, 1962

Earliest planktonic stage is a trochophore; latest stage is a nectochaeta with 20 segments and a length of $1500 \mu \mathrm{m}$. Trochophores are oval, weakly coloured, with red pigment spots arranged in a ring posterior to the well-developed prototroch. Metatrochophore and nectochaeta stages hava a rounded prostomium $; 4$ antennae; 1 large and 1 small pair of red eyes; prototroch and telotroch present; segment 1 dorsally reduced, segment 2 and 3 fused; 4 pairs of cirriform tentacular cirri in the anteriormost segments; setae occur from segment 2 onwards, ventral cirri are present from segment 3 onwards, and dorsal cirri occur from segment 4 onwards; gut with numerous yolk granules. Larvae nearly transparent with a ring of red pigment spots posterior to the prototroch and the telotroch, and additional 2 rows of red pigment spots at the dorsum. Proboscis divided in a smooth, distal part and a proximal part covered with rows of hard papillae, appearing in the late metatrochophore stage. Nectochaetae with a pair of rounded, short anal cirri; \pm rectangular dorsal cirri; subulate ventral cirri, more than twice as long as parapodial lobe and with extremely fine extended tips. Seasonal occurrence: VI-XII

\section{Phyllodoce mucosa Ørsted, 1843 (Figs 67-68)}

Earliest planktonic stage is a trochophore; latest stage is a nectochaeta with 13 segments and a length of $1100 \mu \mathrm{m}$. Trochophores are spherical, blue-green coloured with a yellow-pigmented ring posterior to the prototroch, with apicul tuft. Metatrochophores and nectochaetae with triangular prostomium; 4 antennae; 1 pair of red eyes; prototroch present; segment 1 dorsally reduced, segments 2 and 3 dorsally fused; 4 pairs of cirriform tentacular cirri in the anteriormost segments; setae present from segment 2 onwards, ventral cirri occur from segment 3 onwards, and dorsal cirri are present from segment 4 onwards; 1 pair of cirriform anal cirri. The hyposphere forms a fold posterior to the prototroch, dorsally covering segment 1-3. Distal part of the proboscis is covered with soft papillae, visible in nectochaeta stage. Larvae have weak greenish colour, dorsally with yellow pigment in segments 2 and $3 ; 2$ rows of yellow pigmented spots occur intersegmentally posterior to segment 5 . Dorsal cirri of nectochaeta are \pm rectangular; ventral cirri pointed, somewhat longer than the setal lobe. Seasonal occurrence: III-VI

Figs 67-68. Phyllodoce mucosa; 67: dorsal view of a late metatrochophore with 12 segments; 68: lateral view of a parapodium of a median segment. Figs 69-70. Pisione remota; 69: dorsal view of a pelagic metatrochophore with 5 segments; 70: dorsal view of a benthic juvenile worm after the metamorphosis. Scale bar: 67, 69: $100 \mu \mathrm{m} ; 68: 20 \mu \mathrm{m}_{i} 70: 500 \mu \mathrm{m}$ 

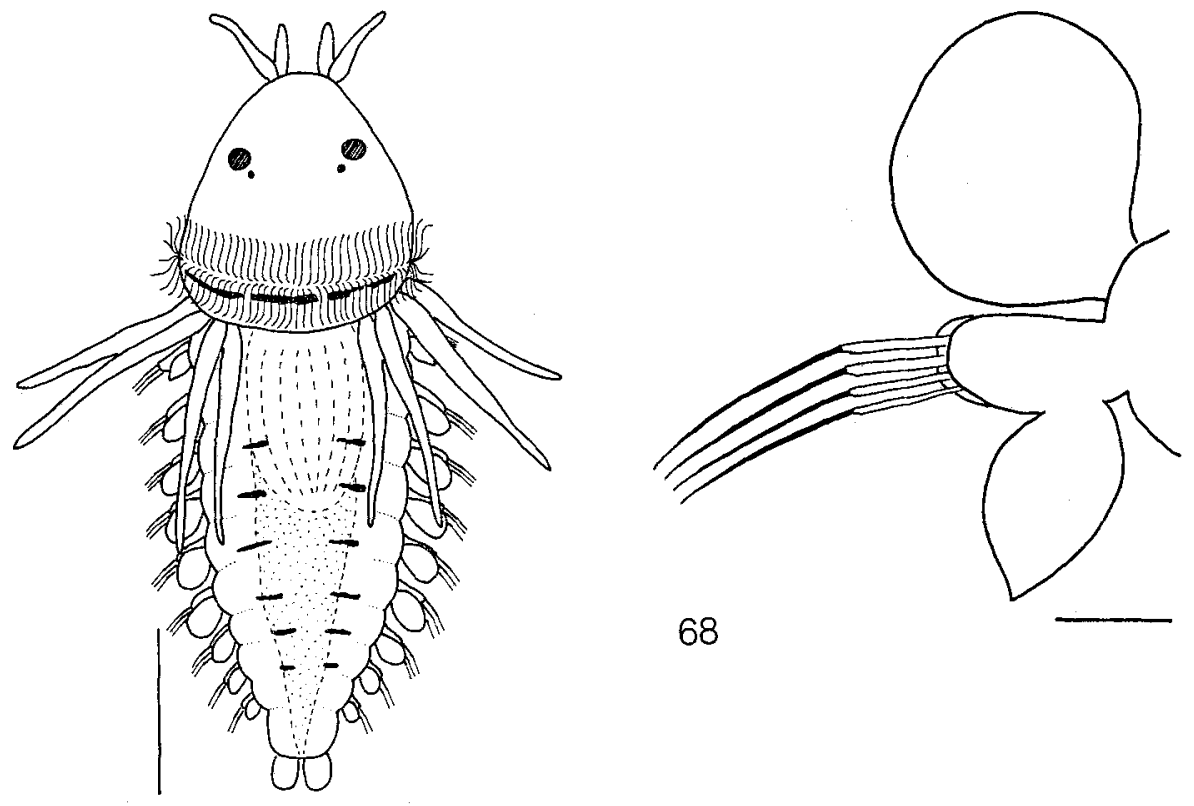

67
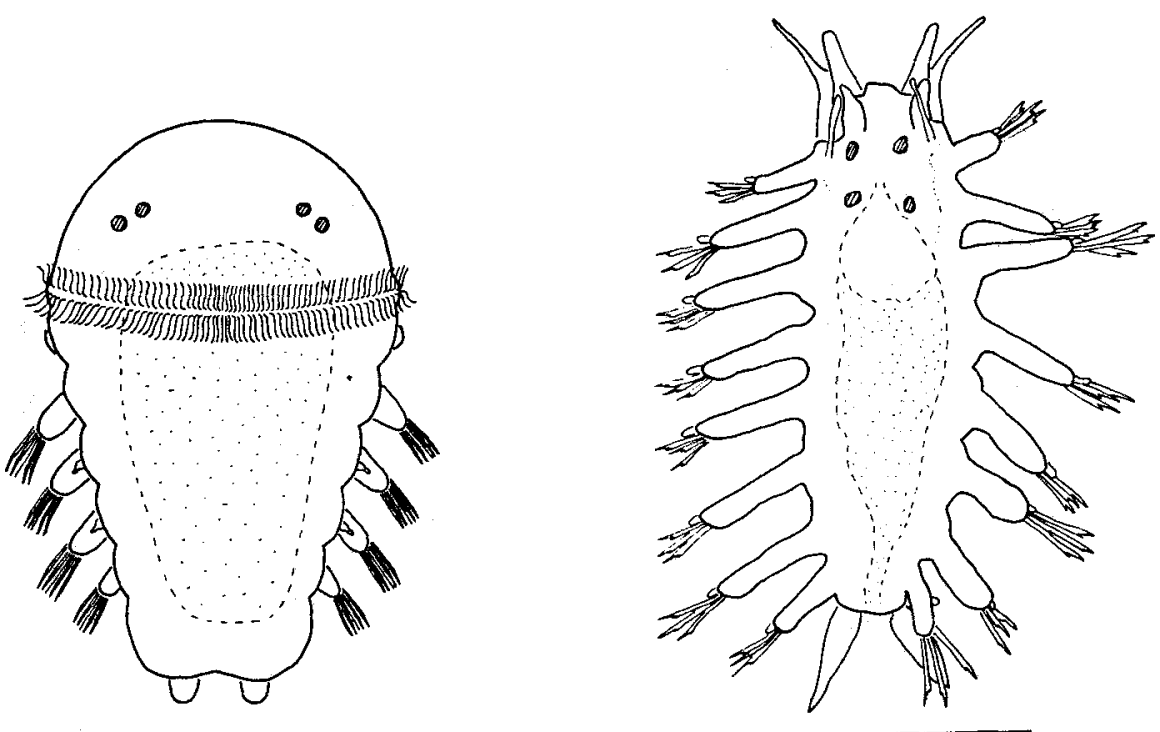

69 


\section{Pisionidae}

\section{Genus Pisione}

Pisione remota (Southern, 1914) (Figs 69-70)

Earliest pelagic stage is a trochophore; latest stage is a nectochaeta with 8 segments and a length of $560 \mu \mathrm{m}$. Trochophores are spherical and transparent, with dark brown coloured gut, proto- and telotroch. One pair of red eyes visible in the late trochophore stage. Metatrochophores and nectochaetae with rounded prostomium; 2 pairs of red eyes; 1 pair of palps; 2 pairs of tentacular cirri in segment 1 ; spherical dorsal and ventral cirri in all segments from segment 2 onwards; segment 1 achaetous; notopodia of the remaining segments with 1 acicula, neuropodia with 1 acicula and compound, falciger setae; acicula strong, capillary with stout end; 2 tapering anal cirri. Older stages also nearly unpigmented with light brown coloured gut. Segment 1 growing around the prostomium during metamorphosis and tentacular cirri become forwardly directed. Seasonal occurrence: VII-X

\section{Nereidae}

\section{Genus Nereis}

Nereis pelagica Linné, 1761 (Fig. 71)

Earliest pelagic stages are cleaved eggs; latest stages are nectochaetae with 4 setigers and a length of $520 \mu \mathrm{m}$. Trochophores are spherical with a median prototroch and bluish-green oil droplets in the gut. Metatrochophores with 3 setigers; prostomium rounded, with 4 eyes; telotroch present. Prostomium with 2 frontal antennae in nectochaetae and erpochaetae; red-brown pigment-patches may occur at one or both sides of the prostomium laterally in front of the eyes; 1 pair of tentacular cirri, arising laterally to and slightly behind the prostomium; parapodia biramous with long, compound, distally uniserrated setae; lateral ciliary bands occur in all segments; pygidium with 1 pair of quickly growing, tapering anal cirri. The larvae are bluish-green coloured by numerous oil droplets in the gut. The proboscis with jaws becomes visible in the nectochaeta stage and is functional just before the larvae begin benthic life. The juvenile benthic worms graze on algae. Seasonal occurrence: III-VI

\section{Genus Neanthes}

Neanthes succinea Frey \& Leuckart, 1847 (Fig. 72)

Earliest planktonic stage is a cleaved egg; latest stage is a nectochaeta with 9 segments and a length of $900 \mu \mathrm{m}$. Trochophores are spherical with a median prototroch and bluish oil droplets in the gut. Metatrochophores with 3 setigers; prostomium rounded, with 4 red eyes; telotroch present. Nectochaeta stage with 2 antennae,

Fig. 71. Nereis pelagica; dorsal view of a planktonic nectochaeta with 4 setigers. Fig. 72. Neanthes succinea; dorsal view of a planktonic nectochaeta with 3 setigers. Fig. 73. Autolytus sp.; dorsal view of a bentho-pelagic larva. Fig. 74. Ophiodromus flexuosus; dorsal view of a planktonic nectochaeta. 


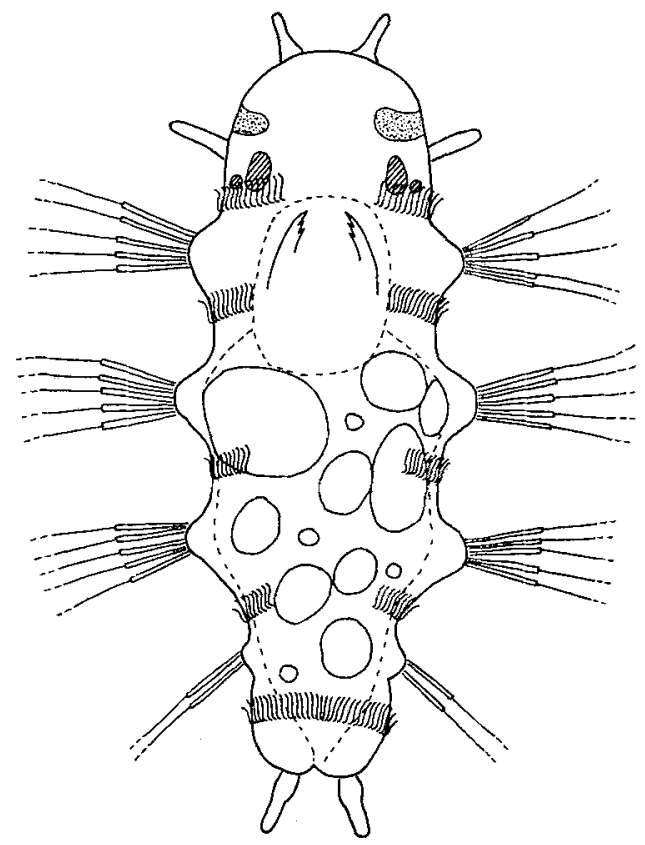

71

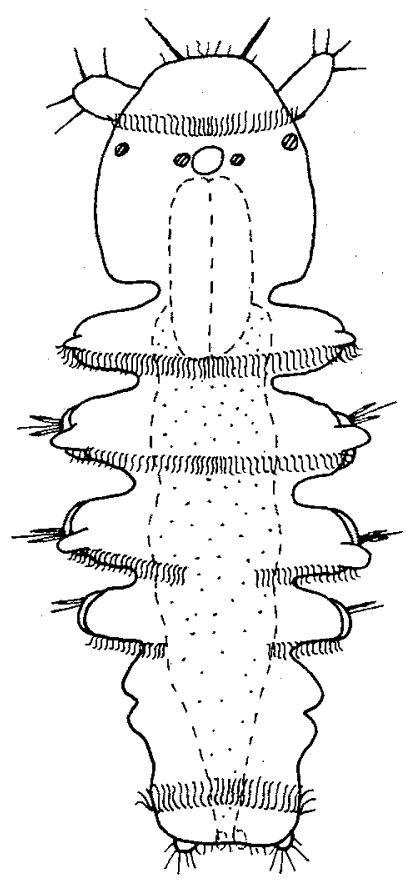

73

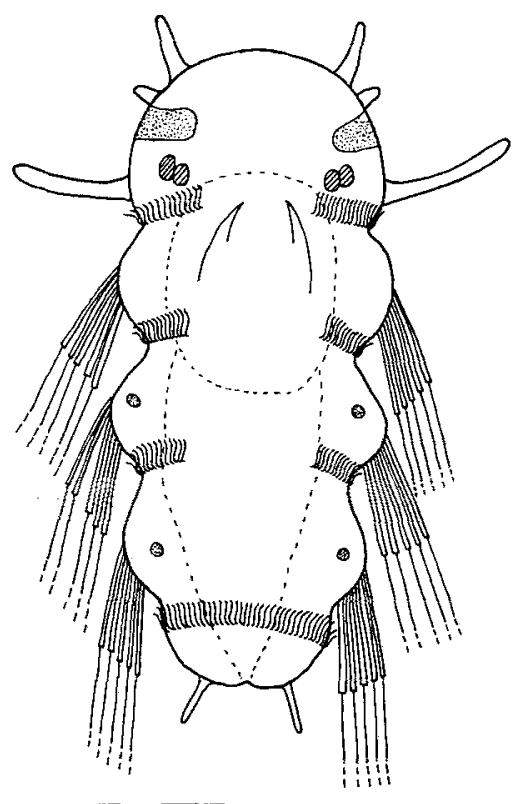

72

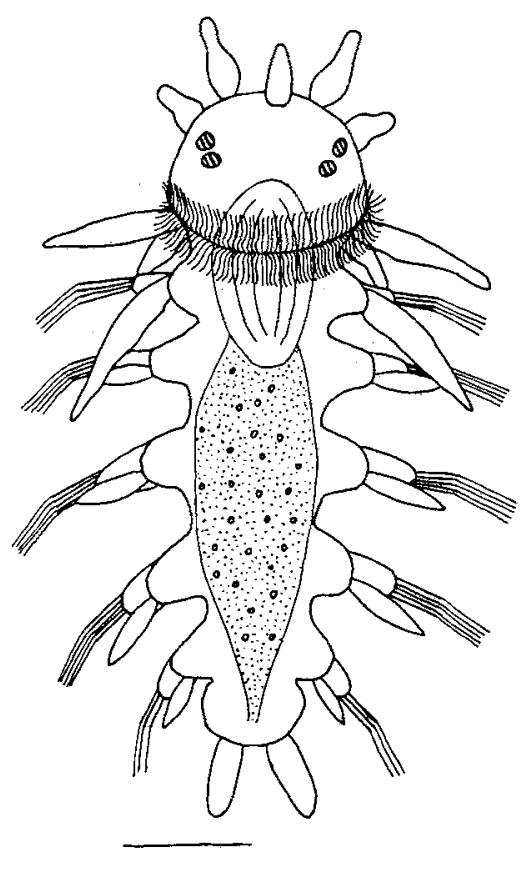

74 
developed at the prostomium; red-brown pigment-patches may occur on one or both sides of the prostomium laterally in front of the eyes; 1 pair of tentacular cirri arises lateral to and slightly behind the prostomium; parapodia biramous with long, compound, distally uniserrated setae; lateral ciliary bands occur in all segments; pygidium with 2 short anal cirri. The larvae are green-brown coloured with numerous oil droplets in the gut. Two rows of red pigmented spots are dorsally visible from segment 2 onwards. The proboscis with jaws is visible in the nectochaeta stage and becomes functional just before the larvae begin benthic life. The juvenile benthic worms graze on algae. Seasonal occurrence: VII-IX

\section{Syllidae}

\section{Genus Autolytus (Fig. 73)}

The pelagic life of syllid larvae is very short and most of the individuals found in the plankton may be resuspended from the bottom. A species determination is not possible due to the very weak morphological differences.

Larvae in the plankton possess $0-3$ setigers and a length of $300-500 \mu \mathrm{m}$. Their body shape is slender, wormlike; prostomium rounded; 3 antennae (may be very short); 2 pairs of red eyes; 2 pairs of short tentacular cirri; acro-, proto- and metatrochs present; telotroch in early stages absent; all trochs weakly developed; segment 1 (= peristomial segment) achaetous; parapodia of the remaining segments uniramous; setae compound, falciger. Proboscis without jaws or papillae; proventriculus not visible until 10 or 11 segments delimited. Seasonal occurrence: VI-IX

\section{Hesionidae}

\section{Genus Ophiodromus}

Ophiodromus flexuosus (Delle Chiaje, 1822) (Fig. 74)

Earliest pelagic stage is a trochophore; latest stage is a nectochaeta with 6 segments and a length of $500 \mu \mathrm{m}$. Trochophores are slightly longer than wide, transparent with green-brown coloured gut; small acrotroch; well-developed prototroch; weakly developed telotroch; episphere with 1 pair of red eyes. Late metatrochophores and nectochaetae with round, dome-shaped prostomium; 3 pairs of red eyes $; 1$ short, round antenna; 1 pair of lateral antenna; 2 very small palps; 2 pairs of tentacular cirri; pygidium with 2 anal cirri; segment 1 achaetous, remaining segments with biramous parapodia; notopodia with simple, spiniger setae and slender dorsal cirri; neuropodia with compound, falciger, uniserrated setae and ventral cirri in all segments from segment 4 onwards; dorsal cirri of segment 2 somewhat longer than in the remaining segments; larvae still unpigmented with greenish-brown gut. The proboscis develops in the late nectochaeta stage and becomes functional after the metamorphosis. Seasonal occurrence: VII-IX 


\section{Serpulidae}

\section{Genus Pomatoceros}

Pomatoceros triqueter (Linné, 1758) (Fig. 75)

Earliest pelagic stage is a trochophore; latest stage is a metatrochophore with $3-4$ segments and a length of $320 \mu \mathrm{m}$. Trochophores are pear-shaped, acro- and prototroch with long cilia, cilia of meta- and telotroch short; 1 pair of black eyes. In metatrochophores prostomium dome-shaped; 3 setigers; parapodia biramous; notopodium with 1-2 simple, distally broadened setae; neuropodium with uncini; pygidium with weakly developed telotroch; bright blue coloured pigment granules in various parts of the body. Seasonal occurrence: VII-X

\section{Nephtyidae}

There are only weak differences in the morphology of the observed larvae belonging to the family Nephtyidae. Therefore, a determination of the larval stages to species level is not possible. The genera Aglaophamus and Nephtys are described for the southern North Sea (Hartmann-Schröder, 1971; Rainer, 1991). Only 4 species of the genus Nephtys IN. caeca (Fabricius, 1780), N. cirrosa Ehlers, 1868, N. hombergii Savigny, 1818, $N$. longosetosa Ørsted, 1842] have been found during benthos investigations in the southeastern part of the German Bight (Stripp, 1969; Hickel et al. 1989; Rainer, 1991). The observed larvae probably belong to this species.

\section{Genus Nephtys (Figs 76-77)}

Earliest planktonic stage is a trochophore; oldest stage is a nectochaeta with 8 segments and a length of $850 \mu \mathrm{m}$. Trochophores are spherical, green pigmented, with proto- and telotroch; eyes absent; gut with some oil droplets. Metatrochophores are cylindrical; prostomium rounded with 1 pair of red eyes; 4-6 segment anlagen. Nectochaetae with angular prostomium; biramous parapodia in all segments; setae strong, simple and spiniger; interramous gills still not differentiated; pygidium with 1 median anal cirrus. Larvae greenish pigmented, sometimes with diatoms in the gut. Seasonal occurrence: III-XII

\section{Orbiniidae}

\section{Scoloplos cf. armiger (O. F. Müller, 1776) (Figs 78-80)}

Earliest pelagic stage is an ovoid trochophore with a length of $\approx 300 \mu \mathrm{m}$; welldeveloped acrotroch and broad prototroch; metatroch slightly weaker and telotroch often incompletely developed; eyes not visible; totally opaque and orange-red coloured. Metatrochophores with well-developed lateral cilia in all body segments, nearly reaching the neurotroch at the ventral side; these ciliary bands are an entirely larval feature and are substituted by capillary setae before the individuals reach the benthic stage. Oldest developmental stage found in the plankton is a bentho-pelagic juvenile with 10-11 setigers and a length of $800-900 \mu \mathrm{m}$; possessing no lateral ciliary bands; branchia anlagen developed from segment 10 onwards; pygidium with 1 pair of anal cirri; body \pm transparent. Seasonal occurrence: II-IV 
Taxonomic note: It is possible that the pelagic larvae appearing in the plankton around Helgoland may belong to another species of the genus Scoloplos, because the development of Scoloplos armiger is described as entirely pelagic in the North Sea (Anderson, 1959). Other than the report on a pelagic development in $S$. armiger from the White Sea (Sveshnikov, 1967), these are the first records of pelagic larvae for the North Sea (Plate \& Husemann, 1991). Without a survey of the benthos of the German Bight it will be impossible to make any definite statement about which species was examined.

\title{
Capitellidae
}

\author{
Genus Capitella \\ "Capitella capitata» (Fabricius, 1780) (Fig. 81)
}

Trochophore and metatrochophore with well-developed proto- and telotroch; broad neurotroch at the ventral side of the body and ciliary bands at the pygidium; without an acro- and metatroch; no lateral ciliary bands; prostomium conical; 1 pair of red eyes; length extremely variable, ranging from ca 130 to $200 \mu \mathrm{m}$; metatrochophore with up to 13 segment anlagen; gut in the posterior part blue-green pigmented; segments 1 to 3 with capillary setae; hooded hooks with 3 teeth above the main fang from segment 4 onwards; numerous, randomly distributed mucous glands over the entire body. Seasonal occurrence: IV-X

Taxonomic note: "Capitella capitata" is known as a species-complex comprising 6 or more species (Grassle \& Grassle, 1976). The material from the North Sea plankton showed no morphological differences that were suitable for species determination.

\section{Genus Heteromastus}

\section{Heteromastus filiformis (Claparède, 1864) (Figs 82-83)}

Earliest planktonic stage is a trochophore with a body length of $\approx 100 \mu \mathrm{m}$; oldest pelagic stage is a metatrochophore with a length of $\approx 340 \mu \mathrm{m}$ and a width of $\approx 160 \mu \mathrm{m}$; trochophore and metatrochophore with $\mathrm{a} \approx 70 \mu \mathrm{m}$ long apical tuft. Larvae with 1 pair of red eyes; well-developed prototroch comprising 2 ciliary rings; telotroch with 1 ciliary ring; transparent body with numerous green chromatophores; gut separated in distinct sections; metatrochophores with up to 8 segment anlagen are characterized by following features: segment 1 achaetous; segment 2 to 4 with capillary setae; from segment 5 onwards hooded hooks with numerous denticles above the main fang. Seasonal occurrence: I-VI

Acknowledgements. Our thanks are due to the staff of the Biologische Anstalt Helgoland and especially to the crew of the R. V. Aade for their friendly assistance. We wish to thank Dr. H.-D. Franke for critically reading the manuscript, and for helpful comments. Parts of this work were supported by grants from the Biologische Anstalt Helgoland.

Fig. 75. Pomatoceros triqueter; pelagic metatrochophore with 3 segments. Figs 76-77. Nephtys sp.; early pelagic nectochaeta; 76: dorsal view; 77: lateral view. Figs. 78-80. Scoloplos cf. armiger; 78: pelagic trochophore; 79 : dorsal view of a late pelagic metatrochophore stage; 80 : ventral view of the same stage. Scale bar: $100 \mu \mathrm{m}$ 


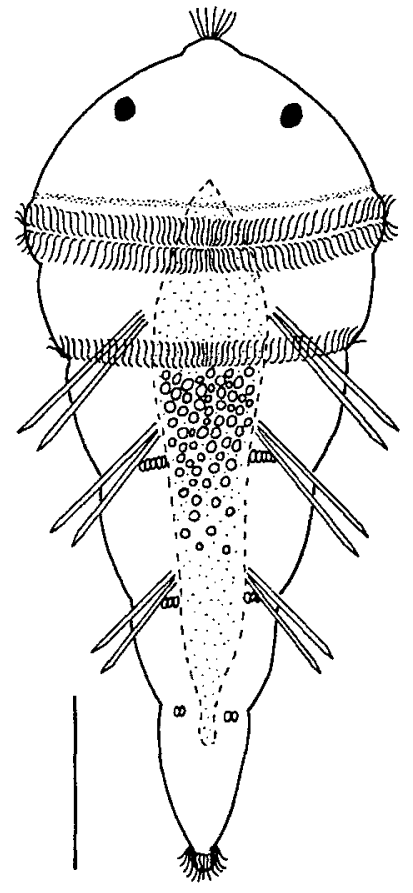

75

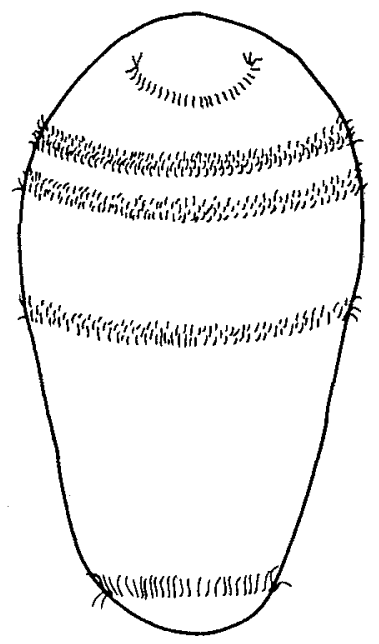

78

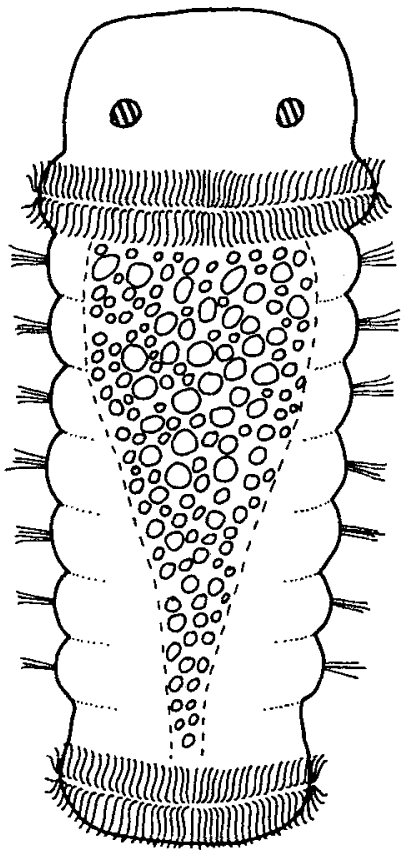

76

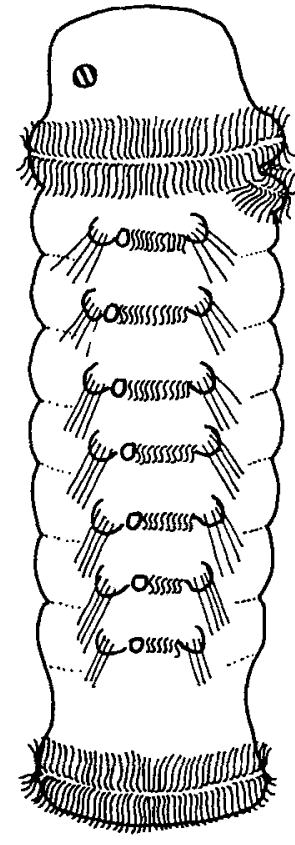

77
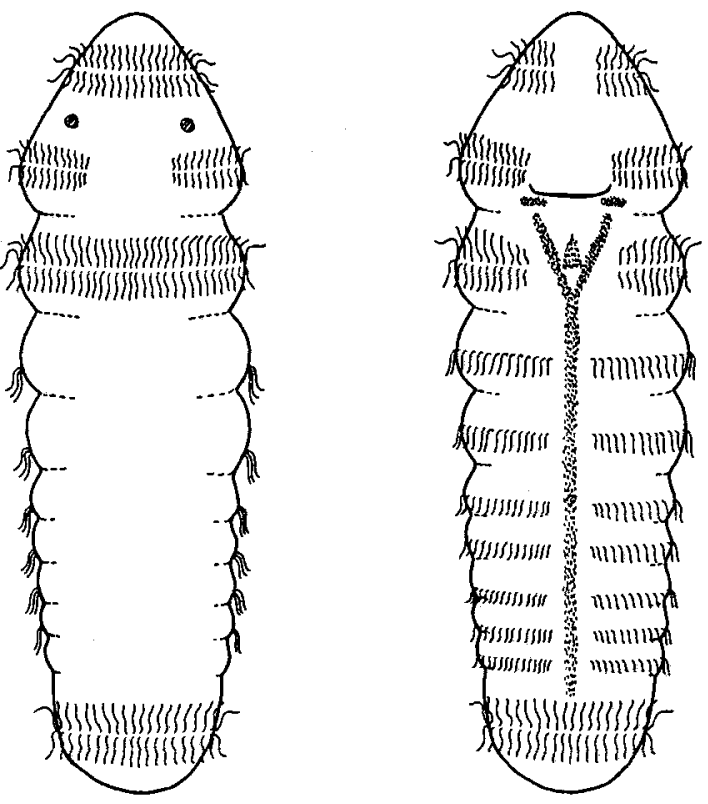

79 


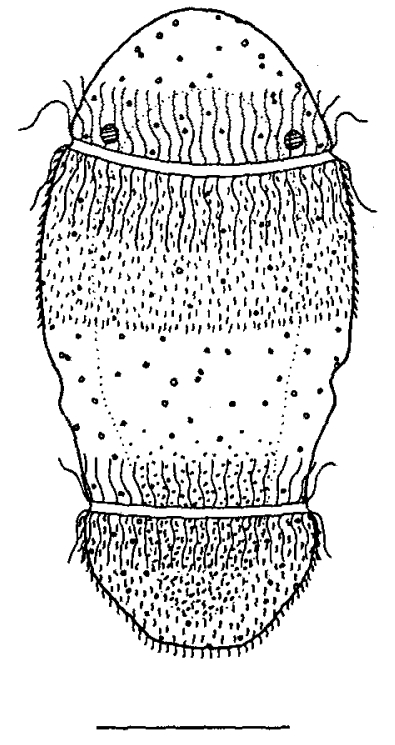

81

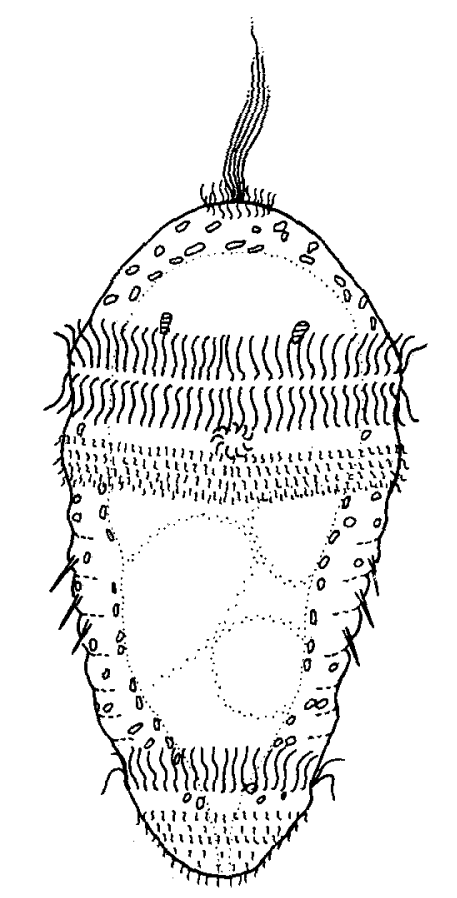

82

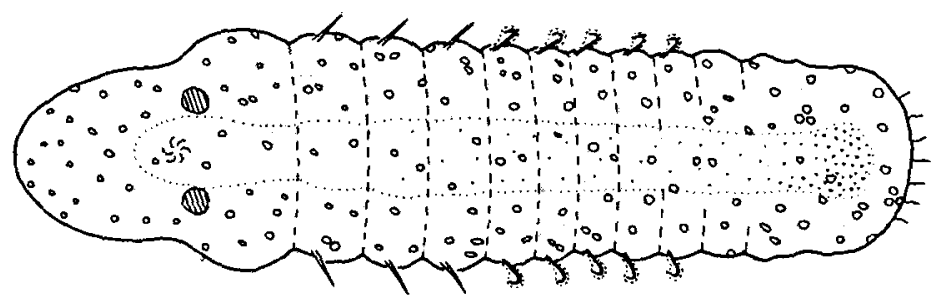

83

Fig. 81. "Capitella capitata»; dorsal view of a planktonic metatrochophore. Figs 82-83. Heteromastus filiformis; 82: pelagic metatrochophore with 7 segment-anlagen; 83: young benthic stage with 10 segments. Scale bar: 81: $50 \mu \mathrm{m}$; 82-83: $100 \mu \mathrm{m}$ 


\section{LITERATURE CITED}

Åkesson, B., 1962. The embryology of Tomopteris helgolandica. - Acta zool. 43, 135-199.

Anderson, D. T., 1959. The embryology of the polychaete Scoloplos armiger. - Q. J1 microsc. Sci. 100, 89-166.

Belgrano, A., Vincx, M., Dewarumez, J. M., Richard, A., Craeymeersch, J. \& Heip, C., 1990. Recruitment of meroplanktonic larvae in the southern bight of the North Sea. - Oceanis 16, 225-243.

Bosselmann, A., 1989. Larval plankton and recruitment of macrofauna in a subtidal area in the German Bight. In: Reproduction, genetics and distribution of marine organisms. Ed. by J. S. Ryland \& P. A. Tyler. Olson \& Olson, Fredensborg, 43-54.

Bosselmann, A., 1991. Recruitment and postlarval growth of some macrozoobenthos species in the German Bight. - Meeresforsch. 33, 141-158.

Caspers، H., 1950. Die Lebensgemeinschaft der Helgoländer Austernbank - Helgoländer wiss. Meeresunters. 3, 119-169.

Cazaux, C., 1968. Étude morphologique du développement larvaire d'annélids polychètes (Bassin d'Arcachon). - Archs Zool. exp. gén. 109, 477-543.

Dörjes, J., 1977. Über die Bodenfauna des Borkum Riffgrundes. - Senkenberg. marit. 9, 1-17.

Fransz, H. G., 1981. List of zooplankton species of the Wadden Sea. - Rep. Wadden Sea Working Group 4, 12-23.

Giere, O., 1968. Die Fluktuationen des marinen Zooplanktons im Elbe-Aestuar. - Arch. Hydrobiol. (Suppl.) 31, 379-546.

Gillandt, L., 1979. Zur Systematik, Autökologie und Biologie der Polychaeten des Helgoländer Felslitorals. - Mitt. hamb. zool. Mus. Inst. 76, 19-73.

Grassle, J. P. \& Grassle, J. F., 1976. Sibling species in the marine pollution indicator Capitella. Science, N.Y. 192, 567-569.

Hannerz, L., 1956. Larval development of the polychaete families Spionidae Sars, Disomidae Mesnil and Poecilochaetidae n. fam. in the Gullmar Fjord (Sweden). - Zool. Bidr. Uppsala 31, 1-204.

Hartmann-Schröder, G., 1971. Annelida, Polychaeta. - Tierwelt Dtl. 58, 1-594.

Hickel, W., Bauerfeind, E., Niermann, U. \& Westernhagen, H. von, 1989. Oxygen deficiency in the south eastern North Sea: possible sources and effects. - Ber. Biol. Anst. Helgoland 4, 1-148.

Husemann, E., 1992. Bestandsaufnahme und Larvenentwicklung der im Helgoländer Plankton auftretenden Polychaeten und Polychaetenlarven - Ordnungen: Phyllodocida, Oweniida, Terebellida, Sabellida und Familien mit unsicherer Ordnungszugehörigkeit. Diss., Univ. Bochum, $222 \mathrm{pp}$.

Kröncke, I., 1991. The macrofauna distribution on the Dogger Bank in April/May 1985-87 (with an annex of unpublished data from Birkett sampled in April/May 1952-54). - Ber. Biol. Anst. Helgoland $8,1-137$.

Nordheim, H. von, 1989. Six new species of Protodrilus (Polychaeta, Annelida) from Europe and New Zealand together with a concise presentation of the genus. - Zool. Scr. 18, 245-268.

Orrhage, L. \& Sundberg, P., 1990. Multivariate analysis of morphometric differentiation within the Laonice-cirrata-group (Polychaeta, Spionidae). - Zool. Scr. 19, 173-178.

Petersen, M. E., 1984. Chaetopterus variopedatus (Renier) (Annelida: Polychaeta: Chaetopteridae): a species complex. What species are being used at MBL? - Biol. Bull. mar. biol. Lab., Woods Hole $167,501-541$.

Petersen, M. E., Chambers, S. \& Heppell, D., 1990. Comments on the proposed conservation of the specific names of Aphrodita imbricata Linnaeus, 1767 (currently Harmothoe imbricata) and Aphrodita minuta Fabricius, 1780 (currently Pholoe minuta) (Annelida, Polychaeta). - Bull. zool. Nom. 47, 207-210.

Plate, S., 1992. Untersuchungen zum zeitlichen Auftreten, zur Abundanz und Entwicklung meroplanktischer Polychaetenlarven im Gebiet Helgoland Reede - Ordnungen Orbiniida, Spionida und Capitellida. Diss., Univ. Bochum, 235 pp.

Plate, S. \& Husemann, E., 1991. An alternative mode of larval development in Scoloplos armiger (O. F. Müller, 1776) (Polychaeta, Orbiniidae). - Helgoländer Meeresunters. 45, 487-492.

Rachor, E., 1990. Changes in sublittoral zoobenthos in the German Bight with regard to eutrophication. - Neth. J. Sea Res. 25, 209-214. 
Rachor, E. \& Gerlach, S. A., 1978. Changes of macrobenthos in a sublittoral sand area of the German Bight, 1967 to 1975. - Rapp. P.-v. Réun. Cons. int. Explor. Mer. 172, 418-431.

Rainer, S. F., 1991. The genus Nephtys (Polychaeta: Phyllodocida) of northern Europe: a review of species, including the description of $N$. pulchra sp. n. and a key to the Nephtyidae. - Helgoländer Meeresunters. 45, 65-96.

Rasmussen, E., 1956. Faunistic and biological notes on marine invertebrates. III. The reproduction and larval development of some polychaetes from Isefjord with some faunistic notes. - Biol. Meddr 23, 1-84.

Salzwedel, H., Rachor, E. \& Gerdes, D., 1985. Benthic macrofauna communities in the German Bight. - Veröff. Inst. Meeresforsch. Bremerh. 20, 199-267.

Smidt, E. L. B., 1951. Animal reproduction in Danish Waddensea. - Meddr Kommn Danm. Fisk.-og Havunders. 11, 1-151.

Stripp, K., 1969. Die Assoziationen des Benthos in der Helgoländer Bucht. - Veröff. Inst. Meeresforsch. Bremerh. 12, 95-142.

Sveshnikov, V. A., 1967. Larvae of archiannelids and polychaetes of the Posset Bay (the Sea of Japan). - Issled. Fauny Moreì 5 (13), 125-159 [in Russian].

Wilson, D. P., 1929. The larvae of the British sabellarians, - J. mar. biol. Ass. U.K. 16, 221-269. 